Western University

Scholarship@Western

Summer 8-28-2015

\title{
Synthesis and Characterization of a Family of Air-Stable Ferrocene- and Ruthenocene-Containing Primary, Secondary, and Tertiary Phosphines
}

Amir Rabiee Kenaree

Tyler J. Cuthbert

Stephanie M. Barbon

Paul D. Boyle

Elizabeth R. Gillies

See next page for additional authors

Follow this and additional works at: https://ir.lib.uwo.ca/chempub

Part of the Chemistry Commons

Citation of this paper:

Rabiee Kenaree, Amir; Cuthbert, Tyler J.; Barbon, Stephanie M.; Boyle, Paul D.; Gillies, Elizabeth R.; Ragogna, Paul J.; and Gilroy, Joe, "Synthesis and Characterization of a Family of Air-Stable Ferrocene- and Ruthenocene-Containing Primary, Secondary, and Tertiary Phosphines" (2015). Chemistry Publications. 68.

https://ir.lib.uwo.ca/chempub/68 


\section{Authors}

Amir Rabiee Kenaree, Tyler J. Cuthbert, Stephanie M. Barbon, Paul D. Boyle, Elizabeth R. Gillies, Paul J. Ragogna, and Joe Gilroy 


\title{
Synthesis and Characterization of a Family of Air-Stable
}

\author{
Ferrocene- and Ruthenocene-Containing Primary, \\ Secondary, and Tertiary Phosphines
}

\author{
Amir Rabiee Kenaree, ${ }^{a, b}$ Tyler J. Cuthbert, ${ }^{a, b}$ Stephanie M. Barbon, ${ }^{a, b}$ Paul D. Boyle, ${ }^{a}$ \\ Elizabeth R. Gillies, ${ }^{a, b, c}$ Paul J. Ragogna, ${ }^{a, b}$ and Joe B. Gilroy* ${ }^{a, b}$
}

\begin{abstract}
${ }^{a}$ Department of Chemistry and ${ }^{b}$ The Centre for Advanced Materials and Biomaterials Research (CAMBR), The University of Western Ontario, 1151 Richmond St. N., London, Ontario, Canada N6A 5B7. ${ }^{c}$ Department of Chemical and Biochemical Engineering, The University of Western Ontario, 1151 Richmond St. N., London, Ontario, Canada N6A 5B9. Phone: +1-519-661-2111 ext. 81561, E-mail: joe.gilroy@uwo.ca.
\end{abstract}




\section{TOC GRAPHIC}

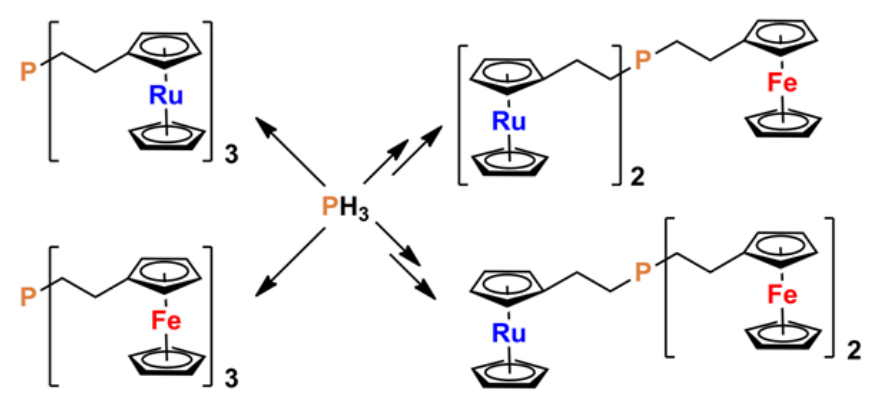

\section{ABSTRACT}

The synthesis and characterization of a family of air-stable primary, secondary, and tertiary phosphines containing all possible combinations of ethylferrocene and ethylruthenocene substituents are reported. Each phosphine was characterized by ${ }^{1} \mathrm{H},{ }^{13} \mathrm{C}$, and ${ }^{31} \mathrm{P}$ NMR spectroscopy, IR and UV-vis absorption spectroscopy, mass spectrometry, and elemental analysis. With the exception of primary ethylruthenocene phosphine 8a, all of the title compounds have been studied by single crystal X-ray crystallography. Ferrocene-containing phosphines showed maximum absorption at wavelengths of $c a .440 \mathrm{~nm}$ and qualitatively reversible oxidation waves in their cyclic voltammograms with intensities scaling to the number of ferrocene units present. The average metal-cyclopentadienyl centroid distances observed for ferrocene-containing phosphines were shorter than those of ruthenocene-containing phosphines, which also had maximum absorption wavelengths of $c a .320 \mathrm{~nm}$ and underwent irreversible electrochemical oxidation. Phosphines containing both ethylferrocene and ethylruthenocene substituents displayed properties consistent with the presence of both metallocene types. 


\section{INTRODUCTION}

Despite their ubiquity in the fields of coordination chemistry and catalysis, ${ }^{1,2}$ phosphines are often overlooked in other areas, including materials science, due to the perception that they react violently when exposed to air. However, many phosphines, including primary and secondary examples, exhibit exceptional stability towards oxygen. ${ }^{3,4}$ Among the most common strategies for the stabilization of phosphines through synthetic variation are the incorporation of steric bulk $(\text { e.g., 1) })^{4 \mathrm{a}, 4 \mathrm{~b}, 4 \mathrm{e}}$ the design of molecules with relatively high energy singly occupied molecular orbitals (SOMOs) for their radical cation forms (e.g., 2), ${ }^{4 \mathrm{~h}, 4 \mathrm{k}, 41,4 \mathrm{n}}$ and the installation of heteroatoms in close proximity to phosphorus leading to localization of the highest occupied molecular orbitals (HOMOs) away from phosphorus (e.g., 3)..$^{4 \mathrm{c}, 4 \mathrm{~d}, 4 \mathrm{o}}$
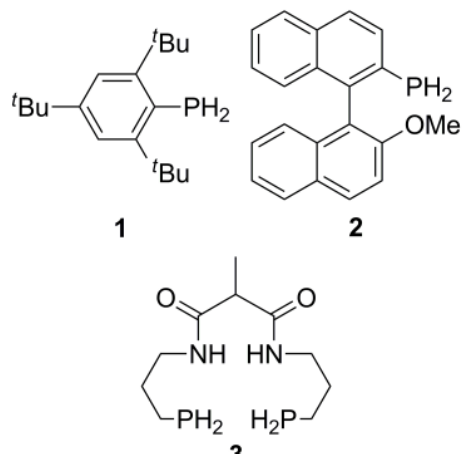

3

Phosphines bearing ferrocene $(\mathrm{Fc})$ substituents combine the desirable characteristics of phosphines and ferrocene, and often exhibit surprising stability towards air and moisture. . $^{4,4 k, 4 m}$ Consequently, they have been utilized as rigid and potentially redox-active ligands for transition metals, e.g., in $\mathrm{Pd}(\mathrm{dppf}) \mathrm{Cl}_{2} 4$ [dppf = 1,1'-bis(diphenylphosphino)ferrocene], ${ }^{5,6}$ as Lewis bases in frustrated Lewis pairs, e.g., $\mathbf{5},{ }^{7}$ and in the synthesis of metal-containing polymers and polymer networks, e.g., 6. ${ }^{4 \mathrm{~m}, 40,8}$ While the properties of ferrocene-based phosphines have been widely explored, reports on ruthenocene (Rc) analogs are relatively scarce throughout the literature. ${ }^{4 \mathrm{n}, 9}$ 
Furthermore, to the best of our knowledge, phosphines bearing more than one type of metallocene have not been reported to date.

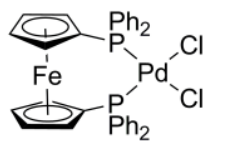

4

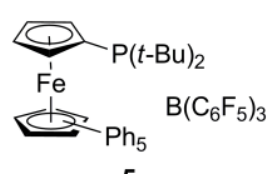

5

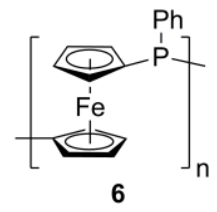

We recently communicated the synthesis of remarkably stable primary, secondary, and tertiary phosphines 7a-c (see structures below) via the radical-catalyzed hydrophosphination of vinylferrocene. This strategy linked the ferrocene units to phosphorus through an ethylene spacer. $^{4 \mathrm{~m}}$ Herein, we present the synthesis and characterization of a family of primary, secondary, and tertiary phosphines that include all possible combinations of ethylferrocene and ethylruthenocene substituents linked to phosphorus.

\section{RESULTS AND DISCUSSION}

\section{Synthesis and NMR Spectroscopy}

Adopting the synthetic strategy employed for the synthesis of primary, secondary, and tertiary ferrocene-containing phosphines $7 \mathbf{a}-\mathbf{c},{ }^{4 \mathrm{~m}}$ vinylruthenocene and phosphine gas $\left(\mathrm{PH}_{3}\right)$ were heated in the presence of azobisisobutyronitrile (AIBN) to produce the corresponding ruthenocenecontaining phosphines 8a-c (Scheme 1). The first step of the reaction involved a large excess of $\mathrm{PH}_{3}$ and resulted mainly in the conversion of vinylruthenocene to primary phosphine $\mathbf{8 a}$. At this stage, the excess $\mathrm{PH}_{3}$ was removed from the reaction flask by purging with nitrogen. Two additional portions of vinylruthenocene and AIBN were then added and the reaction mixture was heated to produce secondary and tertiary phosphines $\mathbf{8 b}$ and $\mathbf{8 c}$. We favored a strategy that 
employed multiple AIBN/vinylruthenocene additions in order to limit radical concentration and disfavor formation of $\alpha$-addition byproducts (i.e., 9). ${ }^{10}$ As vinylruthenocene and primary phosphine 8a have similar polarities, their separation by column chromatography is not trivial. We therefore chose to complete the reaction sequence by charging the mixture with additional AIBN and heating at $85{ }^{\circ} \mathrm{C}$ in order to completely consume excess vinylruthenocene. A typical experiment involving the synthetic strategy described above resulted in isolated yields (after column chromatography in air) of 10\%, 27\%, and 22\% (Yields by NMR spectroscopy: 10\%, $36 \%$, and $48 \%$ ) for $\mathbf{8 a}, \mathbf{8 b}$, and $\mathbf{8 c}$, respectively. Starting from primary and secondary ferrocenecontaining phosphines $\mathbf{7 a}$ and $\mathbf{7 b}$, mixed ferrocene- and ruthenocene-containing phosphines $\mathbf{1 0}$ $(1 \times \mathrm{Rc}, 2 \times \mathrm{Fc}), \mathbf{1 1}(1 \times \mathrm{Rc}, 1 \times \mathrm{Fc})$, and $12(2 \times \mathrm{Rc}, 1 \times \mathrm{Fc})$ were synthesized using similar strategies in $94 \%, 39 \%$, and $42 \%$ isolated yields, respectively (Scheme 1).

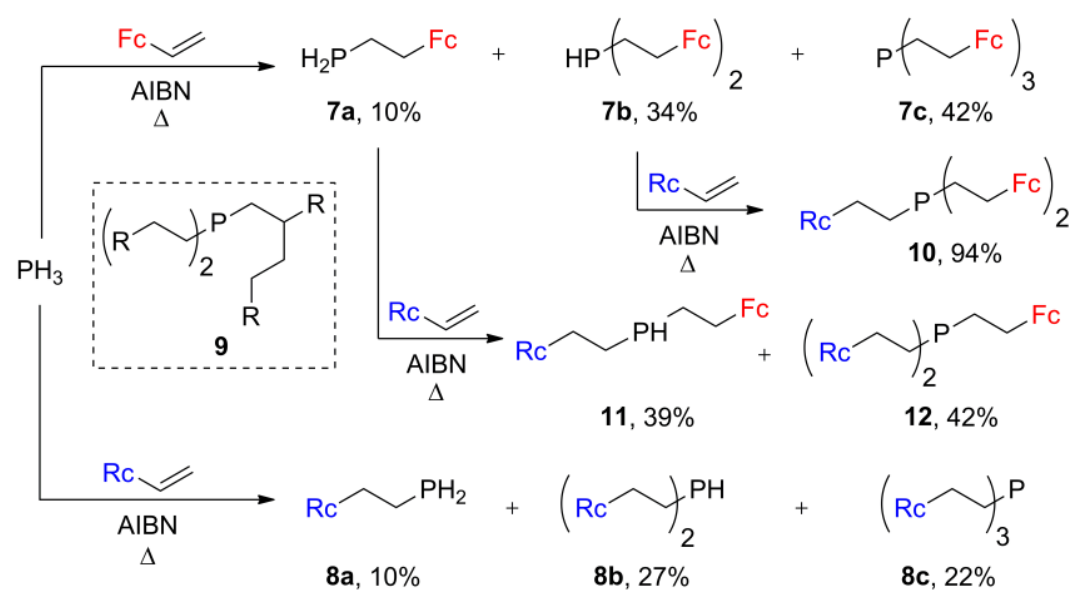

Scheme 1. Synthesis of phosphines $7 \mathbf{a}-\mathbf{c}, \mathbf{8 a}-\mathbf{c}, \mathbf{1 0}, \mathbf{1 1}$, and 12. Fc and Rc represent ferrocene and ruthenocene substituents.

The proposed structures and bulk purity of phosphines $\mathbf{7 a - c},{ }^{4 \mathrm{~m}} \mathbf{8 a}-\mathbf{c}, \mathbf{1 0}, \mathbf{1 1}$, and $\mathbf{1 2}$ were confirmed using ${ }^{1} \mathrm{H},{ }^{13} \mathrm{C}$, and ${ }^{31} \mathrm{P}$ NMR spectroscopy, IR and UV-vis absorption spectroscopy, mass spectrometry, and elemental analysis. Primary phosphines $\mathbf{7 a}$ and $\mathbf{8 a}$ are soluble in a wide 
range of solvents including hexanes, tetrahydrofuran, acetone, ethanol, toluene, dichloromethane, and chloroform. Secondary (7b, 8b, and 11) and tertiary (7c, 8c, 10, and 12) phosphines have limited solubility in hexanes and alcohols, but are soluble in tetrahydrofuran, dichloromethane, and chloroform. Each of the phosphines reported was purified by standard column chromatography techniques and are stable in air indefinitely in the solid state. In solution, each phosphine converts slowly to its corresponding phosphine oxide when exposed to air. The degradation of phosphines $\mathbf{7 a - c}, \mathbf{8 a}-\mathbf{c}, \mathbf{1 0}, \mathbf{1 1}$, and $\mathbf{1 2}$ in solution was studied by monitoring the ${ }^{31} \mathrm{P}$ NMR spectra of $75 \mathrm{mM}$ chloroform- $d$ solutions that were prepared in air and stored in a fume hood for 1 week with no attempt to limit air or light exposure. After 1 week, conversion to phosphine oxides ranged from $0-7.5 \%$ (Table S1). Within the series, primary phosphine $7 \mathbf{a}(1 \times$ Fc) degraded the slowest and tertiary phosphine $8 \mathbf{c}(3 \times \mathrm{Rc})$ degraded the quickest. In general, phosphines containing ruthenocene substituents degraded more quickly than ferrocene analogs.

The ${ }^{31} \mathrm{P}$ NMR spectra of primary, secondary, and tertiary ruthenocene-containing phosphines 8a-c are shown in Figure 1, while proton-coupled and -decoupled ${ }^{31} \mathrm{P}$ NMR spectra for the remaining phosphines can be found in the supporting information. The ${ }^{31} \mathrm{P}$ NMR resonances for the primary (7a and $8 \mathbf{a})$, secondary $(\mathbf{7 b}, \mathbf{8 b}$, and $\mathbf{1 1})$, and tertiary $(\mathbf{7 c}, \mathbf{8 c}, \mathbf{1 0}$, and $\mathbf{1 2})$ phosphines appeared as triplets at approximately $-137 \mathrm{ppm}$, doublets at approximately $-69 \mathrm{ppm}$, and singlets at approximately $-29 \mathrm{ppm}$, respectively. Coupling constants $\left({ }^{1} J_{\mathrm{PH}}\right)$ for primary and secondary phosphines were calculated to be $c a .200 \mathrm{~Hz}$, and were consistent with the coupling constants $\left({ }^{1} J_{\mathrm{HP}}\right)$ observed in the corresponding ${ }^{1} \mathrm{H}$ NMR spectra (Table 1). The ${ }^{1} \mathrm{H}$ NMR spectra collected also confirmed the presence of the ethylene bridge, with peaks appearing between $1.54-1.90$ ppm and 2.28-2.59 ppm in their ${ }^{1} \mathrm{H}$ NMR spectra. Mono-substituted metallocene units were identified by the presence of singlets for unsubsituted cyclopentadienyl (Cp) ligands and pairs of 
pseudo triplets for each substituted Cp ligand between 4.06-4.57 ppm in their ${ }^{1} \mathrm{H}$ NMR spectra (Figures S1-S18).

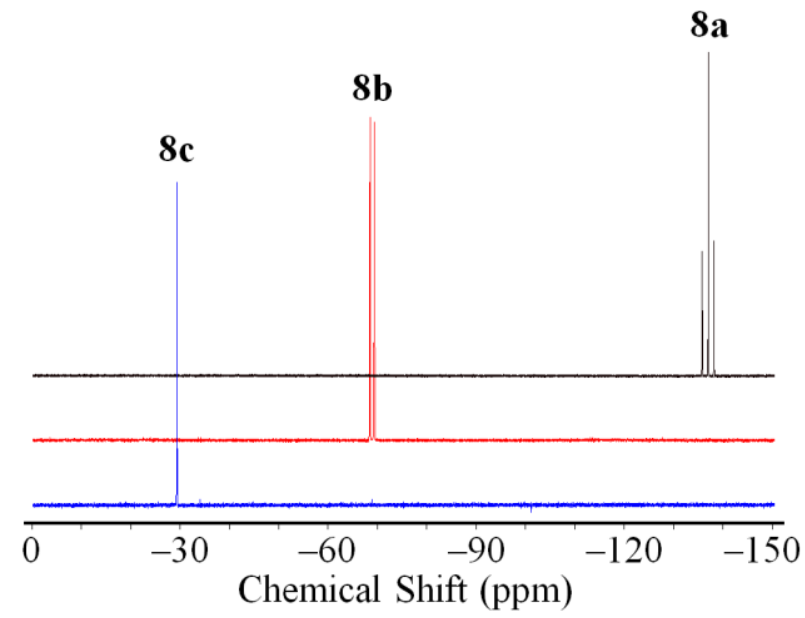

Figure 1. ${ }^{31} \mathrm{P}$ NMR spectra of primary, secondary, and tertiary ruthenocene-containing phosphines 8a-c in chloroform- $d$.

Table 1. Selected characterization data for phosphines 7a-c, 8a-c, 10, 11, and 12.

\begin{tabular}{|c|c|c|c|c|c|c|c|c|c|}
\hline & $7 a^{4 m}$ & $7 \mathbf{b}^{4 \mathrm{~m}}$ & $7 c^{4 m}$ & $\mathbf{8 a}$ & $\mathbf{8 b}$ & $8 c$ & 10 & 11 & 12 \\
\hline M.p. $\left({ }^{\circ} \mathrm{C}\right)$ & $51-53$ & $93-95$ & $119-121$ & $52-54$ & $97-99$ & $110-112$ & $135-137$ & $76-78$ & $106-108$ \\
\hline${ }^{31} \mathrm{P}$ NMR $\operatorname{shift}^{a}(\delta)$ & -137.1 & -68.8 & -27.9 & -137.0 & -68.9 & -29.4 & -28.4 & -68.9 & -28.9 \\
\hline${ }^{1} J_{\mathrm{PH}}(\mathrm{Hz})$ & 196 & 201 & - & 195 & 201 & - & - & 200 & - \\
\hline $\begin{array}{l}\varepsilon(320 \mathrm{~nm})^{b} \\
\left(\mathrm{M}^{-1} \mathrm{~cm}^{-1}\right)\end{array}$ & 75 & 130 & 280 & 210 & 480 & 770 & 375 & 300 & 495 \\
\hline $\begin{array}{l}\varepsilon(440 \mathrm{~nm})^{b} \\
\left(\mathrm{M}^{-1} \mathrm{~cm}^{-1}\right)\end{array}$ & 110 & 195 & 325 & - & - & - & 205 & 105 & 95 \\
\hline $\mathrm{E}_{\mathrm{pa}, \mathrm{Rc}}^{c, d}(\mathrm{mV})$ & - & - & - & 330 & 550 & 490 & 545 & 480 & 495 \\
\hline $\mathrm{E}_{1 / 2, \mathrm{Fc}_{\mathrm{c}}^{c}}(\mathrm{mV})$ & 10 & -10 & 10 & - & - & - & 10 & -10 & 10 \\
\hline
\end{tabular}

${ }^{a}$ Recorded in chloroform- $d .{ }^{b}$ Recorded in tetrahydrofuran. ${ }^{c}$ Recorded at scan rates of $250 \mathrm{mV} \mathrm{s}^{-1}$ in $1 \mathrm{mM}$ dichloromethane solutions containing $0.1 \mathrm{M}$ tetra- $n$-butylammonium triflate as supporting electrolyte and referenced relative to the ferrocene/ferrocenium redox couple. ${ }^{d}$ Irreversible process; anodic peak potential reported.

\section{X-ray crystallography}

The solid-state structures of phosphines $\mathbf{8 b}, \mathbf{8 c}, \mathbf{1 0}, \mathbf{1 1}$, and $\mathbf{1 2}$ were determined via single crystal X-ray diffraction (Figures 2 and S19-S21 and Tables 2 and 3). Structural data for the 
published structures of $\mathbf{7 a - c}$ are included in Table 2 for comparison. As is often observed for solid-state structures containing metallocene units, the structures exhibited elongated displacement ellipsoids due to either large amplitude librations of the $\mathrm{Cp}$ ring about the molecular axis or a static disorder of the $\mathrm{Cp}$ ring over two or more orientations. Furthermore, the metal sites of the mixed-metal metallocene compounds exhibited a statistical disorder of the Fe and $\mathrm{Ru}$ atoms. For this reason, we have chosen to focus on the average $C \mathrm{p}_{\text {centroid }}-\mathrm{Cp} \mathrm{p}_{\text {centroid }}$ and metal- $\mathrm{Cp}_{\text {centroid }}$ distances for our discussion of the solid-state structures of the metallocene units in $\mathbf{8 b}, \mathbf{8 c}, \mathbf{1 0}, \mathbf{1 1}$, and 12. As the Rc/Fc ratio was increased, a clear trend emerged. The average M-C $\mathrm{p}_{\text {centroid }}$ distance increases in tertiary phosphines from $1.653(2) \AA$ in $7 \mathrm{c}(3 \times \mathrm{Fc})$, to $1.706(2)$ $\AA$ in $10(1 \times \mathrm{Rc}, 2 \times \mathrm{Fc})$, to $1.760(2) \AA$ in $\mathbf{1 2}(2 \times \mathrm{Rc}, 1 \times \mathrm{Fc})$, and $1.807(1) \AA$ in $\mathbf{8 c}(3 \times \mathrm{Rc})$.

Each phosphine exhibits a trigonal pyramidal geometry where the average C-P-C angles are $101.2(2)^{\circ}(\mathbf{8 b}), 98.67(4)^{\circ}(\mathbf{8 c}), 99.66(6)^{\circ}(\mathbf{1 0}), 101.5(2)^{\circ}(\mathbf{1 1})$, and $99.63(8)^{\circ}(\mathbf{1 2})$. The average PC bond lengths in the solid-state structures of $\mathbf{8 b}, \mathbf{8 c}, \mathbf{1 0}, \mathbf{1 1}$, and $\mathbf{1 2}$ are $1.846(5) \AA, 1.845(10) \AA$, $1.850(14) \AA, 1.860(8) \AA$, and 1.851(17) $\AA$, respectively. The structural metrics associated with the phosphorus environments found within $\mathbf{8 b}, \mathbf{8 c}, \mathbf{1 0}, \mathbf{1 1}$, and $\mathbf{1 2}$ are consistent with those reported for the all-ferrocene analogs $7 \mathbf{a}-\mathbf{c}$ (Table 2). ${ }^{4 \mathrm{~m}}$

Table 2. Selected average angles (deg) and bond lengths $(\AA)$ for phosphines $\mathbf{7 a}-\mathbf{c}, \mathbf{8 b}, \mathbf{8 c}, \mathbf{1 0}, \mathbf{1 1}$, and 12.

\begin{tabular}{|c|c|c|c|c|c|c|c|c|}
\hline & $7 a^{4 m}$ & $7 b^{4 m}$ & $7 c^{4 m}$ & $\mathbf{8 b}$ & $8 c$ & 10 & 11 & 12 \\
\hline C-P-C & - & $99.03(4)$ & $99.68(6)$ & $101.2(2)$ & $98.67(4)$ & $99.66(6)$ & $101.5(2)$ & $99.63(8)$ \\
\hline $\mathrm{P}-\mathrm{C}$ & $1.883(6)$ & $1.877(7)$ & $1.8505(12)$ & $1.846(5)$ & $1.845(9)$ & $1.8499(13)$ & $1.851(5)$ & $1.8510(17)$ \\
\hline $\begin{array}{c}\text { M-Cp } \text { centroid }_{\text {(unsubstituted } \mathrm{Cp} \text { ) }} \\
\text { (a) }\end{array}$ & $1.660(5)$ & $1.653(8)$ & $1.655(2)$ & $1.822(5)$ & $1.810(1)$ & $1.707(2)$ & $1.734(3)$ & $1.761(2)$ \\
\hline $\begin{array}{c}\mathrm{M}-\mathrm{C} \mathrm{p}_{\text {centroid }} \\
\text { (substituted } \mathrm{Cp} \text { ) }\end{array}$ & $1.665(4)$ & $1.656(8)$ & $1.651(2)$ & $1.815(4)$ & $1.803(1)$ & $1.705(2)$ & $1.732(4)$ & $1.758(2)$ \\
\hline $\mathrm{C} \mathrm{p}_{\text {centroid }}-\mathrm{C} \mathrm{p}_{\text {centroid }}$ & $3.325(5)$ & $3.309(8)$ & $3.306(2)$ & $3.637(5)$ & $3.613(1)$ & $3.412(2)$ & $3.466(4)$ & $3.519(2)$ \\
\hline
\end{tabular}



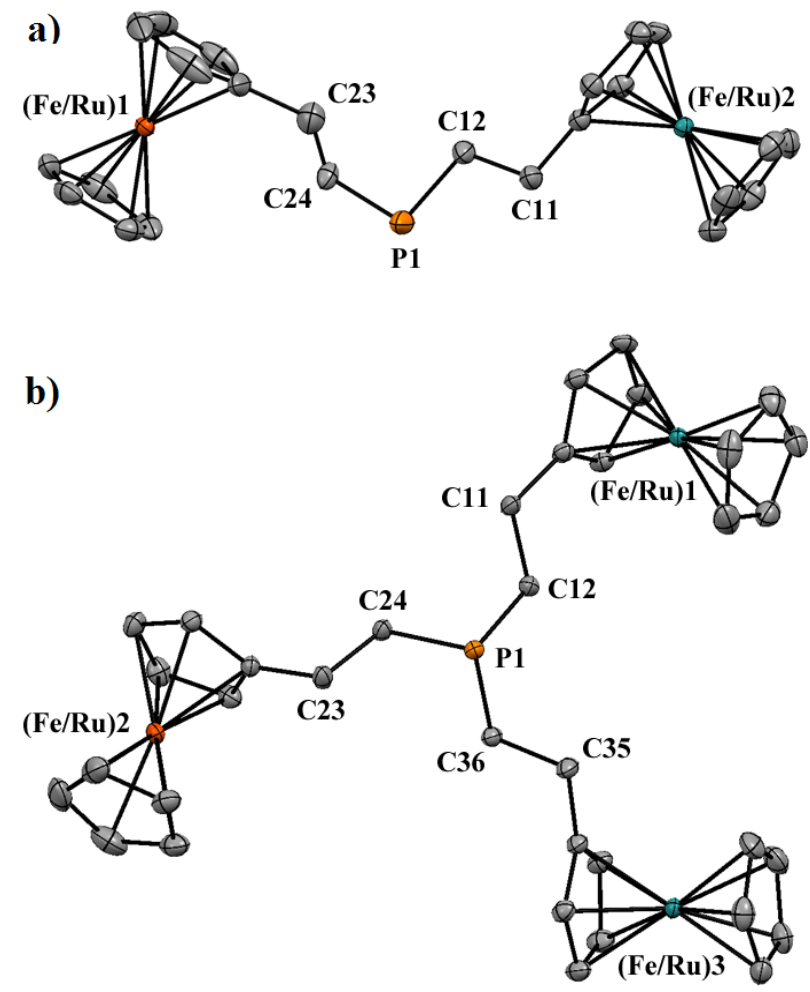

Figure 2. Solid-state structures of a) secondary phosphine $\mathbf{1 1}(1 \times \mathrm{Rc}, 1 \times \mathrm{Fc})$ and b) tertiary phosphine $12(2 \times \mathrm{Rc}, 1 \times \mathrm{Fc})$. Anisotropic displacement ellipsoids are shown at $50 \%$ probability and hydrogen atoms have been omitted for clarity. For depictions of the solid-state structures of $\mathbf{8 b}, \mathbf{8 c}$, and $\mathbf{1 0}$ see supporting information (Figures S19-S21).

\section{UV-vis Absorption Spectroscopy}

The UV-vis absorption spectra of tertiary phosphines $\mathbf{7 c}, \mathbf{8 c}, \mathbf{1 0}$, and $\mathbf{1 2}$ in tetrahydrofuran are shown in Figure 3 and the results are summarized in Table 1. Each phosphine gave rise to a weak absorption spectrum consistent with formally forbidden $\mathrm{d} \rightarrow \mathrm{d}$ electronic transitions associated with $\mathrm{d}^{8}$ ferrocene and/or ruthenocene moieties. Ferrocene-containing phosphines exhibited wavelengths of maximum absorption $\left(\lambda_{\max }\right)$ of approximately $440 \mathrm{~nm}$ with molar extinction coefficients proportional to the number of ferrocene units in their respective structures. However, the molar extinction coefficients $(\varepsilon)$ of the absorption centered at approximately $320 \mathrm{~nm}$ for 
phosphines containing ruthenocene were not strictly proportional to the number of ruthenocenes in the structure as both ferrocene and ruthenocene absorb at $c a .320 \mathrm{~nm}$. Nevertheless, a general trend was observed. As ferrocene groups were replaced by ruthenocene groups the intensity of the absorption peak at $440 \mathrm{~nm}$ decreased and the intensity of the absorption peak at $320 \mathrm{~nm}$ increased. Qualitatively similar trends were observed for the UV-vis absorption spectra of primary phosphines 7a and 8a and secondary phosphines 7b, 8b, and $\mathbf{1 1}$ (Figures S22-26 and Table 1).

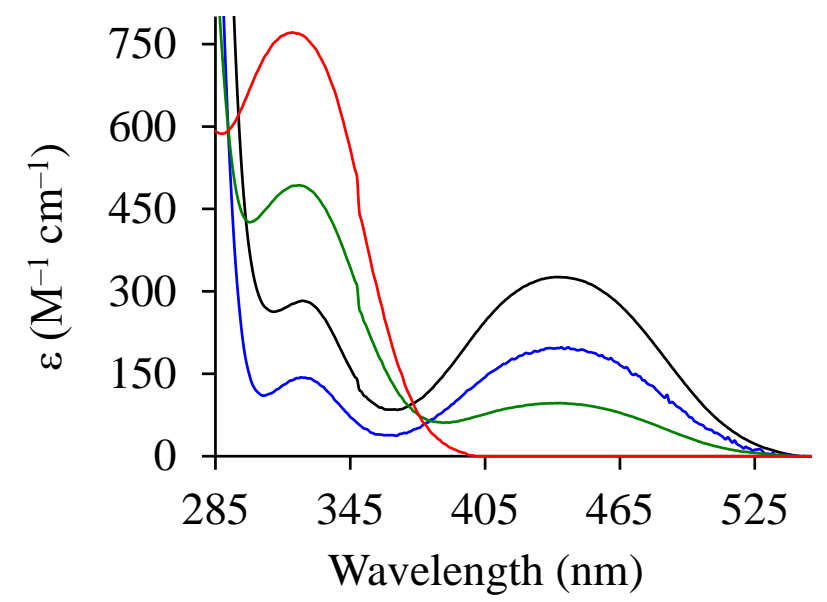

Figure 3. UV-vis spectra of tertiary phosphines 7c $(3 \times$ Fc; black line $), 8 c(3 \times$ Rc; red line $), 10$ $(1 \times \mathrm{Rc}, 2 \times \mathrm{Fc}$; blue line $)$, and $12(2 \times \mathrm{Rc}, 1 \times \mathrm{Fc}$; green line $)$ in tetrahydrofuran.

\section{Cyclic Voltammetry}

The reversible one-electron oxidation of ferrocene is well understood, so much so, that it is commonly used as an internal standard for electrochemical studies. ${ }^{11,12}$ Despite the structural and electronic similarities between ferrocene and ruthenocene, the oxidation behavior of the latter has not been studied to the same extent. Most reports of the oxidation of ruthenocene indicate that it occurs as a two-electron process as $17 \mathrm{e}^{-}\left[\mathrm{Ru}^{\mathrm{III}} \mathrm{Cp}_{2}\right]^{+}$, formed via oxidation of $18 \mathrm{e}^{-}$ $\mathrm{Ru}^{\mathrm{II}} \mathrm{Cp}_{2}$, is extremely Lewis acidic and readily combines with Lewis bases to form $19 \mathrm{e}^{-}$adducts 
that undergo rapid disproportionation (Scheme 2). Previous studies have shown that $\left[\mathrm{Ru}^{\mathrm{III}} \mathrm{Cp}_{2}\right]^{+}$ can scavenge mercury from electrodes, ${ }^{13}$ activate $\mathrm{C}-\mathrm{Br}$ bonds, ${ }^{14}$ bind to solvents such as acetonitrile, ${ }^{15}$ and react with dihalogens such as $\mathrm{I}_{2}$ en route to the formation of $\mathrm{Ru}^{\mathrm{IV}}$ complexes. ${ }^{16}$ However, by using tetra- $n$-butylammonium tetra(pentafluorophenyl)borate, a non-coordinative supporting electrolyte, ${ }^{17}$ Geiger and co-workers have shown that the oxidation of $\mathrm{Ru}^{\mathrm{II}} \mathrm{Cp}_{2}$ involves loss of a single electron. ${ }^{18}$ Depending on the conditions, for example when an ethane bridge is introduced between the cyclopentadienyl substituents in dicarba[2]ruthenocenophanes, oxidation leads to formation of isolable dimers linked through a Ru-Ru bond. ${ }^{14,19}$

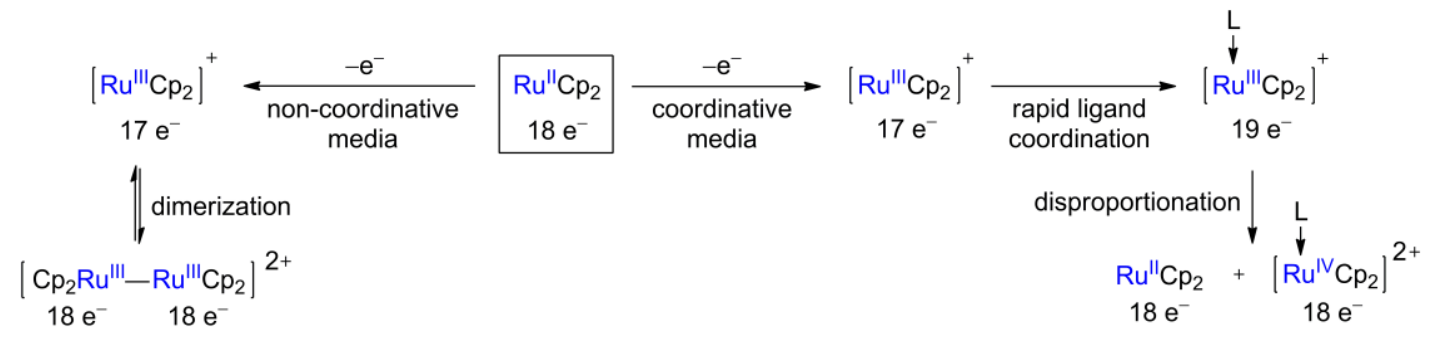

Scheme 2. Summary of the known chemical oxidation behavior of ruthenocene in coordinative/non-coordinative media. $\mathrm{L}=$ neutral or anionic donor.

We have previously reported details of the qualitatively reversible oxidation (one electron per ferrocene) of primary, secondary, and tertiary ferrocene-containing phosphines $7 \mathbf{a}-\mathbf{c}$ in mixtures of dichloromethane and acetonitrile using tetra- $n$-butylammonium triflate as a supporting electrolyte. ${ }^{4 \mathrm{~m}}$ The triflate anions were found to solubilize the polycationic forms of the oxidized phosphines after our initial studies using traditional supporting electrolytes (e.g., tetra-nbutylammonium hexafluorophosphate and tetra- $n$-butylammonium tetrafluoroborate) were plagued by plating of the analyte on the working electrode. For the current study, all solvents and reagents were rigorously purified prior to electrochemical studies and dichloromethane alone was employed as the solvent to avoid the formation of ruthenocenium-acetonitrile adducts during 
the evaluation. The number of electrons involved for each process was determined by relative comparison to the current generated during the oxidation of a stoichiometric amount of decamethylferrocene. ${ }^{20}$ We began the study by collecting cyclic voltammograms of ferrocene and ruthenocene in order to establish 'baseline' behavior under the experimental conditions employed. Ferrocene yielded a reversible one-electron oxidation wave while ruthenocene underwent an irreversible two-electron oxidation with significant cathodic peak current (Figure S27).

The cyclic voltammograms collected for tertiary phosphines $\mathbf{7 c}, \mathbf{8 c}, \mathbf{1 0}$, and $\mathbf{1 2}$ under identical conditions are shown in Figure 4 and the data are summarized in Table 1. For each ferrocenecontaining tertiary phosphine, a small, irreversible oxidation peak at $c a .-100 \mathrm{mV}$ relative to the ferrocene/ferrocenium redox couple was observed. This electrochemical feature may be associated with redox reactivity and/or electrode interactions associated with the phosphorus lone pair as similar electrochemical behavior and conclusions have been reported for related phosphines. $^{4 \mathrm{~g}, 21}$

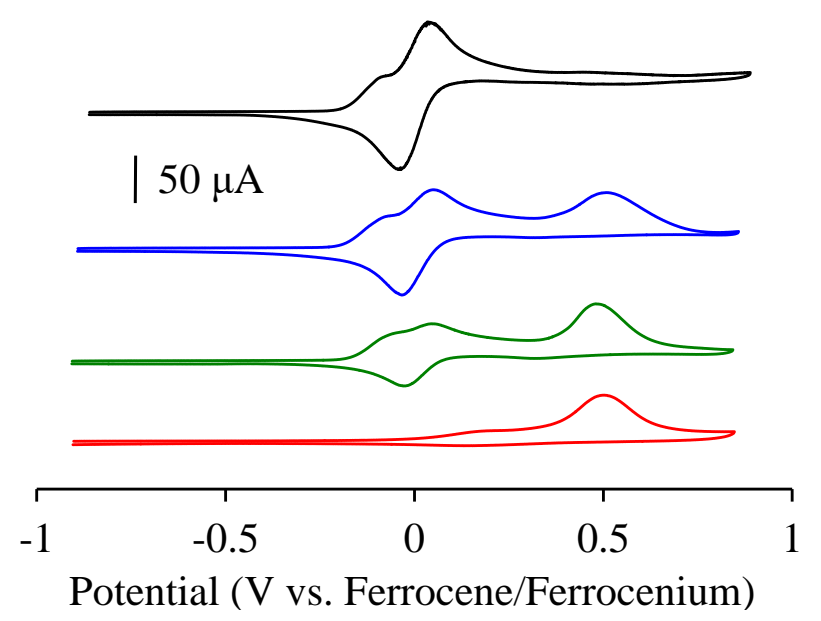

Figure 4. Cyclic voltammograms of tertiary phosphines 7c $(3 \times \mathrm{Fc}$; black line $), \mathbf{8 c}(3 \times \mathrm{Rc}$; red line), $10(1 \times \mathrm{Rc}, 2 \times \mathrm{Fc}$; blue line $)$, and $12(2 \times \mathrm{Rc}, 1 \times \mathrm{Fc}$; green line $)$ recorded at $250 \mathrm{mV} \mathrm{s}^{-1}$ in $1 \mathrm{mM}$ solutions of dichloromethane containing $0.1 \mathrm{M}$ tetra- $n$-butylammonium triflate as supporting electrolyte. 
Although the ferrocene moieties present in $\mathbf{7 a - c}, \mathbf{1 0}, \mathbf{1 1}$, and $\mathbf{1 2}$ underwent qualitatively reversible electrochemical oxidation $\left(\mathrm{E}_{1 / 2, \mathrm{Fc}} \sim 0 \mathrm{mV}\right)$, irreversible oxidation events $\left(\mathrm{E}_{\mathrm{pa}, \mathrm{Rc}}\right.$ $330-550 \mathrm{mV}$ ) were observed for the ruthenocene groups in each of the ruthenocene-containing phosphines. The anodic current response did not scale linearly with the number of ruthenocene moieties present. For these compounds, we postulate that the initial formation of $17 \mathrm{e}^{-}$ ruthenocenium is rapidly followed by the formation of a $19 \mathrm{e}^{-}$adduct. Specifically, we suggest that intermolecular complexes form between phosphines in the vicinity of the working electrode and electrochemically-generated ruthenocenium compounds $\left(\right.$ e.g., $\left.\quad\left[\mathrm{R}_{3} \mathrm{P} \rightarrow \mathrm{Ru}^{\mathrm{III}} \mathrm{Cp}_{2}\right]^{+}\right)$. The resulting adducts can decompose or disproportionate to produce a variety of different stable $18 \mathrm{e}^{-}$ species (Scheme 3). At lower scan rates $\left(50-250 \mathrm{mV} \mathrm{s}^{-1}\right)$, decomposition of the complexes generated during the cyclic voltammetry studies (e.g., $\left[\mathrm{R}_{3} \mathrm{P} \rightarrow \mathrm{Ru}^{\mathrm{IV}} \mathrm{Cp}_{2}\right]$ ) may lead to the irreversible oxidation behavior observed. When scan rates were increased $\left(500-1000 \mathrm{mV} \mathrm{s}^{-1}\right)$ the oxidation waves observed were irreversible and the anodic peak current responses approached the two-electrons per ruthenocene we initially expected. Furthermore, at high scan rates (2000-8000 $\mathrm{mV} \mathrm{s}^{-1}$ ), reduction half waves potentially associated with the re-formation of ruthenocene were observed (Figure S28), providing further indication that the species generated during the cyclic voltammetry studies are short lived. While the fate of the ruthenocene moieties is not clear, the qualitatively reversible oxidation of ferrocene in all cases implies that the ferrocene/ferrocenium redox couple is not involved in any of the proposed disproportionation and/or decomposition pathways. This behavior was in stark contrast to that observed for the electrochemical oxidation of ruthenocene under identical conditions, where the observed oxidation wave was accompanied by a corresponding reduction wave with significant peak current. 


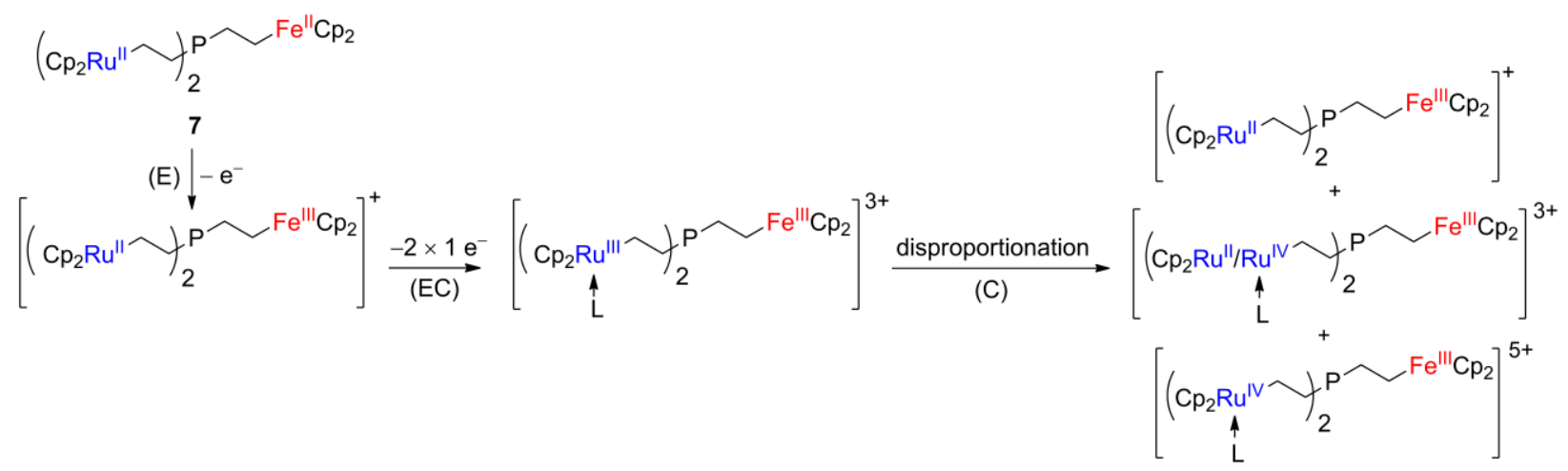

Scheme 3. Postulated reactivity pathway upon electrochemical oxidation of tertiary phosphine $12(2 \times \mathrm{Rc}, 1 \times \mathrm{Fc}) . \mathrm{L}=$ phosphine or triflate anion, $\mathrm{E}=$ electrochemical reaction, $\mathrm{C}=$ chemical reaction, and $\mathrm{EC}=$ electrochemical/chemical reaction.

The electrochemical behavior of primary and secondary phosphines $7 \mathbf{a}, \mathbf{7 b}, \mathbf{8 a}, \mathbf{8 b}$, and 11 were found to be qualitatively similar to that described above (Figures S29 and S30 and Table 1). For each ferrocene-containing primary and secondary phosphine, a qualitatively reversible oxidation wave with anodic/cathodic peak currents corresponding to one electron per ferrocene was observed. For each ruthenocene-containing phosphine, an irreversible oxidation wave associated with the ruthenocene moiety was observed.

\section{CONCLUSION}

During this study, we have demonstrated that the radical-catalyzed hydrophosphination of alkenes can be used to produce primary, secondary, and tertiary ferrocene- and ruthenocenecontaining phosphines. The phosphines, which degrade slowly when exposed to air in solution and are stable indefinitely in the solid state, exhibited properties consistent with the presence of ferrocene and/or ruthenocene moieties. Phosphines containing one or more ferrocenes underwent qualitatively reversible oxidation (one electron per ferrocene), and absorbed visible light at a 
maximum of $440 \mathrm{~nm}$. Analogs containing ruthenocene underwent irreversible electrochemical oxidation (two electrons per ruthenocene at high scan rates), consistent with the phosphines themselves coordinating to electrochemically generated ruthenocenium. They also showed characteristic wavelengths of maximum absorption at $320 \mathrm{~nm}$. Phosphines containing both ferrocene and ruthenocene showed properties associated with both types of metallocenes, with the relative intensity of their UV-vis absorption and electrochemical responses qualitatively relating to the number of each type of metallocene present. Our future work in this area will focus on the utilization of these phosphines as metal carriers for the preparation of highlymetallized polymers and crosslinked polymer networks.

\section{EXPERIMENTAL SECTION}

\section{General Considerations}

All reactions and manipulations were carried out under a nitrogen atmosphere using standard Schlenk techniques unless otherwise stated. Solvents were obtained from Caledon Laboratories, dried using an Innovative Technologies Inc. solvent purification system, collected under vacuum, and stored under a nitrogen atmosphere over $4 \AA$ molecular sieves. All reagents were purchased from Sigma-Aldrich or Alfa Aesar and used as received. Ferrocenecarboxaldehyde and ruthenocenecarboxaldehyde were synthesized according to literature procedures ${ }^{22}$ and vinylruthenocene, ${ }^{23}$ vinylferrocene, ${ }^{23}$ and ferrocene-containing phosphines $\mathbf{7 a - c}$ were synthesized according to modified literature procedures. ${ }^{4 m}{ }^{1} \mathrm{H},{ }^{13} \mathrm{C}$, and ${ }^{31} \mathrm{P}$ NMR spectra were recorded on a $600 \mathrm{MHz}\left({ }^{1} \mathrm{H}: 599.5 \mathrm{MHz},{ }^{13} \mathrm{C}: 150.8 \mathrm{MHz},{ }^{31} \mathrm{P}: 242.6 \mathrm{MHz}\right)$ Varian INOVA instrument. ${ }^{1} \mathrm{H}$ NMR spectra were referenced to residual $\mathrm{CHCl}_{3}(7.27 \mathrm{ppm})$ and ${ }^{13} \mathrm{C} \mathrm{NMR}$ spectra were referenced to chloroform- $d(77.0 \mathrm{ppm}) .{ }^{31} \mathrm{P}$ NMR spectra were referenced internally 
relative to triphenyl phosphine ( $-6.0 \mathrm{ppm}$ relative to phosphoric acid). Mass spectrometry data were recorded using a high resolution Finnigan MAT 8400 spectrometer, in positive-ion mode. UV-vis spectra were recorded using a Cary 300 Scan instrument. Infrared spectra were recorded using a PerkinElmer Spectrum Two FTIR spectrometer with an attenuated total reflectance (ATR) attachment and a single reflection diamond. Elemental analyses ( $\mathrm{C}$ and $\mathrm{H})$ were carried out by Laboratoire d'Analyse Élémentaire de l'Université de Montréal, Montréal, QC, Canada.

\section{Cyclic Voltammetry}

Cyclic voltammograms were collected using a Bioanalytical Systems Inc. (BASi) Epsilon potentiostat and analyzed using BASi Epsilon software. Typical electrochemical cells consisted of a three-electrode setup including a glassy carbon working electrode, platinum wire counter electrode, and silver wire pseudo-reference electrode. Experiments were run at variable scan rates in degassed dichloromethane solutions of the analyte $(\sim 1 \mathrm{mM})$ and supporting electrolyte (0.1 M tetra- $n$-butylammonium triflate) under a blanket of argon. Cyclic voltammograms were referenced against an internal standard $(1 \mathrm{mM}$ decamethylferrocene: $-520 \mathrm{mV}$ vs ferrocene/ferrocenium under identical conditions) and corrected for internal cell resistance using the BASi Epsilon software.

\section{X-ray Crystallography}

Single crystals of all compounds suitable for X-ray diffraction studies were grown from concentrated tetrahydrofuran solutions of the compounds layered with hexanes, except for tertiary phosphine $\mathbf{8 c}$, which was grown by vapor diffusion of pentane into a concentrated chloroform solution. The samples were mounted on a MiTeGen polyimide micromount with a small amount of Paratone N oil. All X-ray measurements were made on a Bruker APEX-II CCD diffractometer. The unit cell dimensions were determined from a symmetry constrained fit of 
9813 reflections with $6.48^{\circ}<2 \theta<68.96^{\circ}$ for $\mathbf{8 b}, 8712$ reflections with $5.54^{\circ}<2 \theta<46.48^{\circ}$ for 8c, 9847 reflections with $5.88^{\circ}<2 \theta<79.26^{\circ}$ for 10,9849 reflections with $5.50^{\circ}<2 \theta<63.22^{\circ}$ for $\mathbf{1 1}$, and 9420 reflections with $6.86^{\circ}<2 \theta<79.66^{\circ}$ for $\mathbf{1 2}$. The data collection strategy was a

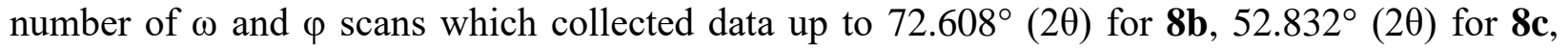
$80.634^{\circ}(2 \theta)$ for $\mathbf{1 0}, 63.400^{\circ}(2 \theta)$ for $\mathbf{1 1}$, and $87.406^{\circ}(2 \theta)$ for $\mathbf{1 2}$, respectively. The frame integration was performed using SAINT. ${ }^{24}$ The resulting raw data were scaled and absorption corrected using a multi-scan averaging of symmetry equivalent data using SADABS, ${ }^{25}$ except the data for $\mathbf{8 b}$ which were processed using TWINABS. ${ }^{26}$ The crystal of $\mathbf{8 b}$ was nonmerohedrally twinned (see supporting information for twin law). The twin fraction of the minor domain refined to a value of $0.4120(7)$. The structures for $\mathbf{8 b}, \mathbf{8 c}, \mathbf{1 0}, \mathbf{1 1}$, and $\mathbf{1 2}$ were solved using the SHELXT program. ${ }^{27}$ All non-hydrogen atoms were obtained from the initial solution. The hydrogen atoms were introduced at idealized positions and were allowed to ride on the parent atom. The structural model was fit to the data using full matrix least-squares based on $\mathrm{F}^{2}$ corrections for anomalous dispersion from the usual tabulation. The structure was refined using the SHELXL-2014 program from the SHELX program package. ${ }^{28}$ Structural disorder related to the ethylene linkers and the unsubstituted $\mathrm{Cp}$ ligands was modeled under unconstrained conditions. For tertiary phosphine $\mathbf{8 c}$, the minor component of the rotational disorder associated with two of the unsubstituted $\mathrm{Cp}$ ligands could not be fully resolved (see .cif file for details). For phosphines 10, 11, and 12 the occupancy of the metal sites were fixed to the stoichiometric ratios of $\mathrm{Fe} / \mathrm{Ru}$, as confirmed by elemental analysis. Graphic plots were produced using Mercury software (version 3.3). For additional collection and refinement details, see Table S2. 


\section{CAUTION: $\mathbf{P H}_{3}$ gas is toxic and pyrophoric}

$\mathrm{PH}_{3}$ gas must be handled carefully in a controlled environment. The use of commercially available personal and laboratory $\mathrm{PH}_{3}$ detectors during all experiments involving $\mathrm{PH}_{3}$ is strongly advised. Reactions should be conducted in high-pressure reactors and purged thoroughly with inert gas $\left(\right.$ e.g., $\mathrm{N}_{2}$ ) before they are opened inside a glove box. Excess $\mathrm{PH}_{3}$ should be ignited as it is purged from the reaction vessel under controlled conditions. Please see Figure S31 for photographs of the experimental apparatus used in this study.

\section{Preparation of vinylferrocene}

Vinylferrocene was prepared according to a modified literature procedure. ${ }^{23}$ In a three-neck round bottom flask equipped with a dropping funnel, methyltriphenylphosphonium iodide (18.700 g, $46.032 \mathrm{mmol})$, potassium $t$-butoxide $(6.000 \mathrm{~g}, 53.47 \mathrm{mmol})$ and dibenzo-18-crown-6 $(0.030 \mathrm{~g}, 0.083 \mathrm{mmol})$ were dissolved in $400 \mathrm{~mL}$ of dry tetrahydrofuran and the resulting solution was allowed to stir for $2 \mathrm{~h}$ at $22{ }^{\circ} \mathrm{C}$. In a dropping funnel, ferrocenecarboxaldehyde (7.363 g, $34.40 \mathrm{mmol}$ ) was dissolved in $100 \mathrm{~mL}$ of dry tetrahydrofuran and added dropwise to the solution. The solution was allowed to stir for $16 \mathrm{~h}$ at $22{ }^{\circ} \mathrm{C}$ before it was treated with $300 \mathrm{~mL}$ of brine. Vinylferrocene was extracted with several portions of diethyl ether. The extracts were combined, washed with $2 \times 300 \mathrm{~mL}$ of brine, $2 \times 300 \mathrm{~mL}$ of deionized water, and dried over $\mathrm{MgSO}_{4}$. After gravity filtration, the solvent was removed in vacuo before the resulting residue was dissolved in hexanes and filtered through a silica plug $(2 " \times 3$ "). Pure vinylferrocene was isolated as an orange microcrystalline solid by removing the solvent. Yield $=7.076 \mathrm{~g}, 97 \% .{ }^{1} \mathrm{H}$ NMR $(599.5 \mathrm{MHz}$, chloroform- $d): \delta 6.46\left(\mathrm{~d}\right.$ of d, ${ }^{3} J_{\mathrm{HH}, \text { cis }}=11 \mathrm{~Hz},{ }^{3} J_{\mathrm{HH}}$, trans $=18 \mathrm{~Hz}, 1 \mathrm{H}$, $\left.\mathrm{C}_{5} \mathrm{H}_{4} \mathrm{CH}\right), 5.35\left(\mathrm{~d}\right.$ of d, ${ }^{2} J_{\mathrm{HH}, \text { gem }}=2 \mathrm{~Hz},{ }^{3} J_{\mathrm{HH}, \text { trans }}=18 \mathrm{~Hz}, 1 \mathrm{H}$, trans $\left.-\mathrm{CHCH}_{2}\right), 5.03\left(\mathrm{~d}\right.$ of d, ${ }^{2} J_{\mathrm{HH}}$, gem $=2 \mathrm{~Hz},{ }^{3} J_{\mathrm{HH}, \text { cis }}=11 \mathrm{~Hz}, 1 \mathrm{H}$, cis- $\left.\mathrm{CHCH}_{2}\right), 4.37\left(\mathrm{t},{ }^{3} J_{\mathrm{HH}}=2 \mathrm{~Hz}, 2 \mathrm{H}, \beta-\mathrm{C}_{5} H_{4} \mathrm{R}\right), 4.22\left(\mathrm{t},{ }^{3} J_{\mathrm{HH}}=\right.$ 
$\left.2 \mathrm{~Hz}, 2 \mathrm{H}, \alpha-\mathrm{C}_{5} \mathrm{H}_{4} \mathrm{R}\right)$, and $4.12\left(\mathrm{~s}, 5 \mathrm{H}, \mathrm{C}_{5} \mathrm{H}_{5}\right)$. These data are consistent with those reported previously. ${ }^{23}$

\section{Preparation of vinylruthenocene}

Vinylruthenocene was prepared according to a modified literature procedure. ${ }^{23}$ In a three-neck round bottom flask equipped with a dropping funnel, methyltriphenylphosphonium iodide $(18.700 \mathrm{~g}, 46.032 \mathrm{mmol})$, potassium $t$-butoxide $(6.000 \mathrm{~g}, 53.47 \mathrm{mmol})$ and dibenzo-18-crown-6 $(0.030 \mathrm{~g}, 0.083 \mathrm{mmol})$ were dissolved in $400 \mathrm{~mL}$ of dry tetrahydrofuran and the resulting solution was allowed to stir for $2 \mathrm{~h}$ at $22{ }^{\circ} \mathrm{C}$. In a dropping funnel, ruthenocenecarboxaldehyde (8.919 g, $34.40 \mathrm{mmol}$ ) was dissolved in $100 \mathrm{~mL}$ of dry tetrahydrofuran and added dropwise to the solution. The solution was allowed to stir for $16 \mathrm{~h}$ at $22{ }^{\circ} \mathrm{C}$ before it was treated with $300 \mathrm{~mL}$ of brine. Vinylruthenocene was extracted with several portions of diethyl ether. The extracts were combined, washed with $2 \times 300 \mathrm{~mL}$ of brine, $2 \times 300 \mathrm{~mL}$ of deionized water, and dried over $\mathrm{MgSO}_{4}$. After gravity filtration, the solvent was removed in vacuo before the resulting residue was dissolved in hexanes and filtered through a silica plug (2" $\times 3$ "). Pure vinylruthenocene was isolated as a pale yellow microcrystalline solid by removing the solvent. Yield $=8.517 \mathrm{~g}, 96 \% .{ }^{1} \mathrm{H}$ NMR $(599.5 \mathrm{MHz}$, chloroform- $d): \delta 6.34\left(\mathrm{~d}\right.$ of d, ${ }^{3} J_{\mathrm{HH}}$, cis $=11 \mathrm{~Hz}$, $\left.{ }^{3} J_{\mathrm{HH}, \text { trans }}=18 \mathrm{~Hz}, 1 \mathrm{H}, \mathrm{C}_{5} \mathrm{H}_{4} \mathrm{CH}\right), 5.29\left(\mathrm{~d}\right.$ of d, ${ }^{2} J_{\mathrm{HH}}$ gem $=2 \mathrm{~Hz},{ }^{3} J_{\mathrm{HH}}$, trans $=18 \mathrm{~Hz}, 1 \mathrm{H}$, trans$\left.\mathrm{CHCH}_{2}\right), 4.90\left(\mathrm{~d}\right.$ of d, $\left.{ }^{2} \mathrm{~J}_{\mathrm{HH}, \text { gem }}=2 \mathrm{~Hz},{ }^{3} \mathrm{~J}_{\mathrm{HH}, \text { cis }}=11 \mathrm{~Hz}, 1 \mathrm{H}, \mathrm{cis}-\mathrm{CHCH}_{2}\right), 4.78\left(\mathrm{t},{ }^{3} \mathrm{~J}_{\mathrm{HH}}=2 \mathrm{~Hz}\right.$, $\left.2 \mathrm{H}, \beta-\mathrm{C}_{5} H_{4} \mathrm{R}\right), 4.57\left(\mathrm{t},{ }^{3} \mathrm{~J}_{\mathrm{HH}}=2 \mathrm{~Hz}, 2 \mathrm{H}, \alpha-\mathrm{C}_{5} H_{4} \mathrm{R}\right)$, and $4.52\left(\mathrm{~s}, 5 \mathrm{H}, \mathrm{C}_{5} \mathrm{H}_{5}\right)$. These data are consistent with those previously reported. ${ }^{29}$

\section{Preparation of primary, secondary, and tertiary ferrocene-containing phosphines 7a-c}

Phosphines 7a-c were synthesized according to a literature procedure. ${ }^{4 \mathrm{~m}}$ However in an effort to reduce decomposition of phosphines during column chromatography, triethylamine $[10 \%$ 
(v/v) relative to dry silica] was added to the silica slurry in hexanes before the slurry was transferred to the column, which was later washed with pure hexanes $(3 \times$ volume of the column $)$ to remove excess triethylamine. Using this column $(1.5 " \times 10 "), \mathrm{N}_{2}$ pressure, and a gradient solvent strategy, primary phosphine 7a (hexanes as eluent), secondary phosphine 7b (99:1 hexanes:diethyl ether as eluent), and tertiary phosphine 7c (9:1 hexanes:diethyl ether as eluent) were isolated in $10 \%, 34 \%$, and $42 \%$ yield, respectively. ${ }^{31} \mathrm{P}$ NMR $(161.8 \mathrm{MHz}$, chloroform- $d): \delta$ primary phosphine 7a: $-137.1\left(\mathrm{t},{ }^{1} J_{\mathrm{PH}}=196 \mathrm{~Hz}\right)$; secondary phosphine $7 \mathbf{b}:-68.8\left(\mathrm{~d},{ }^{1} J_{\mathrm{PH}}=201\right.$ $\mathrm{Hz}$ ); and tertiary phosphine 7c: -27.9 (s). These data are consistent with a previous report. ${ }^{4 \mathrm{~m}}$

\section{Preparation of primary, secondary, and tertiary ruthenocene-containing phosphines 8a-c}

In a $300 \mathrm{~mL}$ autoclave, vinylruthenocene $(1.200 \mathrm{~g}, 4.664 \mathrm{mmol})$ and AIBN $(0.030 \mathrm{~g}, 0.18$ mmol) were dissolved in $150 \mathrm{~mL}$ dry toluene. The autoclave was degassed by $\mathrm{N}_{2}$ purging for 10 min before it was pressurized with $\mathrm{PH}_{3}$ to 80 psi. The solution was allowed to stir for $16 \mathrm{~h}$ at 45 ${ }^{\circ} \mathrm{C}$ at which time the pressurized $\mathrm{PH}_{3}$ gas was released in a controlled environment where it was ignited and allowed to burn. The resulting $\mathrm{P}_{4} \mathrm{O}_{10}$ was treated with water to from $\mathrm{H}_{3} \mathrm{PO}_{4}$ and discarded appropriately. The resulting solution was then transferred to a $350 \mathrm{~mL}$ grease-free Schlenk flask, which was charged with vinylruthenocene (1.200 g, $4.664 \mathrm{mmol})$ and AIBN $(0.030 \mathrm{~g}, 0.18 \mathrm{mmol})$ before it was allowed to stir for $16 \mathrm{~h}$ at $45{ }^{\circ} \mathrm{C}$ then $8 \mathrm{~h}$ at $65{ }^{\circ} \mathrm{C}$. Vinylruthenocene $(0.720 \mathrm{~g}, 2.80 \mathrm{mmol})$ and AIBN $(0.018 \mathrm{~g}, 0.11 \mathrm{mmol})$ were added to the reaction flask for a second time and the pale yellow solution was allowed to stir at $45{ }^{\circ} \mathrm{C}$ for 16 h, followed by stirring at $65{ }^{\circ} \mathrm{C}$ for $6 \mathrm{~h}$, before AIBN ( $\left.0.015 \mathrm{~g}, 0.091 \mathrm{mmol}\right)$ was added to the reaction flask for a last time and the solution was allowed to stir at $85{ }^{\circ} \mathrm{C}$ for $3 \mathrm{~h}$ before it was mixed with celite, concentrated in vacuo, and transferred to the top of a silica column. In an effort to reduce the degree of decomposition of phosphines during column chromatography, 
triethylamine $[10 \%(\mathrm{v} / \mathrm{v})$ relative to dry silica] was added to the silica slurry in hexanes before the slurry was transferred to the column and later washed with pure hexanes $(3 \times$ volume of the column) to remove excess triethylamine. Using this column $(1.5 ” \times 10 ")$ and a gradient solvent strategy, primary phosphine $\mathbf{8 a}$, secondary phosphine $\mathbf{8 b}$, and tertiary phosphine $\mathbf{8 c}$ were separated (see below).

\section{Primary phosphine $8 \boldsymbol{8}$}

Using $\mathrm{N}_{2}$ pressure and 95:5 hexanes:diethyl ether solvent mixture as eluent, primary phosphine 8a $\left(R_{f}=0.41\right.$, untreated silica TLC plate) was isolated from the column. The solution containing 8a was concentrated in vacuo to yield a white solid. Yield $=0.350$ g, 10\%. M.p. $52-54{ }^{\circ} \mathrm{C} .{ }^{1} \mathrm{H}$ NMR $\left(599.5 \mathrm{MHz}\right.$, chloroform- $d$ ): $\delta 4.53\left(\mathrm{~s}, 5 \mathrm{H}, \mathrm{C}_{5} H_{5}\right), 4.52\left(\mathrm{t},{ }^{3} \mathrm{~J}_{\mathrm{HH}}=2 \mathrm{~Hz}, 2 \mathrm{H}\right.$, $\beta$ - $\left.\mathrm{C}_{5} H_{4} \mathrm{R}\right), 4.45\left(\mathrm{t},{ }^{3} J_{\mathrm{HH}}=2 \mathrm{~Hz}, 2 \mathrm{H}, \alpha-\mathrm{C}_{5} H_{5} \mathrm{R}\right), 2.72\left(\mathrm{~d}\right.$ of m, $\left.{ }^{1} J_{\mathrm{HP}}=195 \mathrm{~Hz}, 2 \mathrm{H}, \mathrm{P} H_{2}\right), 2.40(\mathrm{~m}$, $\left.2 \mathrm{H}, \mathrm{C}_{5} \mathrm{H}_{4} \mathrm{CH}_{2}\right), 1.65\left(\mathrm{~m}, 2 \mathrm{H}, \mathrm{CH}_{2} \mathrm{PH}_{2}\right) .{ }^{13} \mathrm{C}\left\{{ }^{1} \mathrm{H}\right\}$ NMR (150.1 MHz, chloroform- $\left.d\right): \delta 93.0(\mathrm{~d}$, ${ }^{3} J_{\mathrm{CP}}=6 \mathrm{~Hz}$, ipso- $\left.C_{5} \mathrm{H}_{4} \mathrm{R}\right), 70.5\left(\mathrm{~s}, \beta-C_{5} \mathrm{H}_{4} \mathrm{R}\right), 70.4\left(\mathrm{~s}, C_{5} \mathrm{H}_{5}\right), 69.4\left(\mathrm{~s}, \alpha-C_{5} \mathrm{H}_{4} \mathrm{R}\right), 32.8\left(\mathrm{~d},{ }^{2} J_{\mathrm{CP}}=3\right.$ $\left.\mathrm{Hz}, \mathrm{C}_{5} \mathrm{H}_{4} \mathrm{CH}_{2}\right), 16.0\left(\mathrm{~d},{ }^{1} J_{\mathrm{CP}}=8 \mathrm{~Hz}, \mathrm{CH}_{2} \mathrm{PH}\right) .{ }^{31} \mathrm{P}$ NMR $(161.8 \mathrm{MHz}$, chloroform- $d$ ): $\delta-137.0(\mathrm{t}$ of $\left.\mathrm{m},{ }^{1} J_{\mathrm{PH}}=195 \mathrm{~Hz}\right)$. FT-IR/ATR: 3084 (w), 2916 (w), 2281 (s), 1433 (w), 1222 (w), $1099(\mathrm{~m})$, 995 (m), 806 (s) $\mathrm{cm}^{-1}$. UV-vis (tetrahydrofuran): $\lambda_{\max } 319 \mathrm{~nm}\left(\varepsilon=210 \mathrm{M}^{-1} \mathrm{~cm}^{-1}\right)$. Mass Spec. (EI, +ve mode): exact mass calculated for $\left[\mathrm{C}_{12} \mathrm{H}_{15} \mathrm{P}^{102} \mathrm{Ru}\right]^{+}$: 291.9955; exact mass found: 291.9955; difference: 0 ppm. Anal. Calcd. (\%) for $\mathrm{C}_{12} \mathrm{H}_{15} \mathrm{PRu}$ : C, 49.48; H, 5.19. Found: $\mathrm{C}$, $50.15 ; \mathrm{H}, 5.25$.

\section{Secondary phosphine $8 \boldsymbol{b}$}

After removal of primary phosphine $\mathbf{8 a}$, secondary phosphine $\mathbf{8 b}$ was isolated from the column by changing the elution solvent to $4: 1$ hexanes:diethyl ether $\left(\mathrm{R}_{\mathrm{f}}=0.58\right.$, untreated silica TLC plate). The solution containing $\mathbf{8 b}$ was concentrated in vacuo to yield a white solid. Yield $=$ 
0.897 g, 27\%. M.p. $97-99{ }^{\circ} \mathrm{C} .{ }^{1} \mathrm{H}$ NMR $(599.5 \mathrm{MHz}$, chloroform- $d): \delta 4.54\left(\mathrm{t},{ }^{3} J_{\mathrm{HH}}=2 \mathrm{~Hz}, 4 \mathrm{H}\right.$, $\beta$ - $\left.\mathrm{C}_{5} H_{4} \mathrm{R}\right), 4.53\left(\mathrm{~s}, 10 \mathrm{H}, \mathrm{C}_{5} H_{5}\right), 4.46\left(\mathrm{t},{ }^{3} J_{\mathrm{HH}}=2 \mathrm{~Hz}, 4 \mathrm{H}, \alpha-\mathrm{C}_{5} H_{5} \mathrm{R}\right), 3.16\left(\mathrm{~d}\right.$ of m, ${ }^{1} J_{\mathrm{HP}}=201 \mathrm{~Hz}$, $1 \mathrm{H}, \mathrm{PH}), 2.36\left(\mathrm{~m}, 4 \mathrm{H}, \mathrm{C}_{5} \mathrm{H}_{4} \mathrm{CH}_{2}\right), 1.72\left(\mathrm{~d}\right.$ of $\left.\mathrm{m},{ }^{2} J_{\mathrm{HP}}=70 \mathrm{~Hz}, 4 \mathrm{H}, \mathrm{CH}_{2} \mathrm{PH}\right) .{ }^{13} \mathrm{C}\left\{{ }^{1} \mathrm{H}\right\} \mathrm{NMR}$ $(150.1 \mathrm{MHz}$, chloroform- $d)$ : $\delta 93.5\left(\mathrm{~d},{ }^{3} J_{\mathrm{CP}}=10 \mathrm{~Hz}\right.$, ipso- $\left.C_{5} \mathrm{H}_{4} \mathrm{R}\right), 70.6\left(\mathrm{~s}, \beta-C_{5} \mathrm{H}_{4} \mathrm{R}\right), 70.4(\mathrm{~s}$, $\left.C_{5} \mathrm{H}_{5}\right), 69.4\left(\mathrm{~s}, \alpha-C_{5} \mathrm{H}_{4} \mathrm{R}\right), 28.2\left(\mathrm{~d},{ }^{1} J_{\mathrm{CP}}=12 \mathrm{~Hz}, C \mathrm{H}_{2} \mathrm{PH}\right), 22.3\left(\mathrm{~d},{ }^{2} J_{\mathrm{CP}}=10 \mathrm{~Hz}, \mathrm{C}_{5} \mathrm{H}_{4} C \mathrm{H}_{2}\right) \cdot{ }^{31} \mathrm{P}$ NMR (161.8 MHz, chloroform- $d$ ): $\delta-68.9\left(\mathrm{~d}\right.$ of m, $\left.{ }^{1} J_{\mathrm{PH}}=201 \mathrm{~Hz}\right)$. FT-IR/ATR: 3083(w), 2920 (w), $2252(w), 1442(w), 1227(w), 1100(m), 995(m), 803(s)$, and $667(w) \mathrm{cm}^{-1}$. UV-vis (tetrahydrofuran): $\lambda_{\max } 319 \mathrm{~nm}\left(\varepsilon=480 \mathrm{M}^{-1} \mathrm{~cm}^{-1}\right)$. Mass Spec. (EI, +ve mode): exact mass calculated for $\left[\mathrm{C}_{24} \mathrm{H}_{27} \mathrm{P}^{96} \mathrm{Ru}^{99} \mathrm{Ru}\right]^{+}$: 540.9986; exact mass found: 540.9975; difference: -2.03 ppm. Anal. Calcd. (\%) for $\mathrm{C}_{24} \mathrm{H}_{27} \mathrm{PRu}_{2}: \mathrm{C}, 52.55 ; \mathrm{H}, 4.96$. Found: C, 52.84; H, 4.95.

\section{Tertiary phosphine $8 \mathrm{c}$}

After removal of secondary phosphine $\mathbf{8 b}$, tertiary phosphine $\mathbf{8 c}$ was also collected from the column by changing the elution solvent to a 1:1 mixture of hexanes:diethyl ether $\left(\mathrm{R}_{\mathrm{f}}=0.40\right.$, untreated silica TLC plate). The solution containing 8c was concentrated in vacuo to yield a white solid. Yield $=0.704$ g, $22 \%$. M.p. $110-112{ }^{\circ} \mathrm{C} .{ }^{1} \mathrm{H}$ NMR $(599.5 \mathrm{MHz}$, chloroform- $d$ ): $\delta$ $4.55\left(\mathrm{t},{ }^{3} J_{\mathrm{HH}}=2 \mathrm{~Hz}, 6 \mathrm{H}, \beta-\mathrm{C}_{5} H_{4} \mathrm{R}\right), 4.54\left(\mathrm{~s}, 15 \mathrm{H}, \mathrm{C}_{5} H_{5}\right), 4.47\left(\mathrm{t},{ }^{3} J_{\mathrm{HH}}=2 \mathrm{~Hz}, 6 \mathrm{H}, \alpha-\mathrm{C}_{5} H_{5} \mathrm{R}\right), 2.31$ $\left(\mathrm{m}, 6 \mathrm{H}, \mathrm{C}_{5} \mathrm{H}_{4} \mathrm{CH}_{2}\right), 1.59\left(\mathrm{~m}, 6 \mathrm{H}, \mathrm{CH}_{2} \mathrm{P}\right) .{ }^{13} \mathrm{C}\left\{{ }^{1} \mathrm{H}\right\}$ NMR (150.1 MHz, chloroform- $d$ ): $\delta 93.8(\mathrm{~d}$, ${ }^{3} J_{\mathrm{CP}}=12 \mathrm{~Hz}$, ipso- $\left.C_{5} \mathrm{H}_{4} \mathrm{R}\right), 70.5\left(\mathrm{~s}, \beta-C_{5} \mathrm{H}_{4} \mathrm{R}\right), 70.4\left(\mathrm{~s}, C_{5} \mathrm{H}_{5}\right), 69.4\left(\mathrm{~s}, \alpha-C_{5} \mathrm{H}_{4} \mathrm{R}\right), 28.7\left(\mathrm{~d},{ }^{2} J_{\mathrm{CP}}=\right.$ $\left.13 \mathrm{~Hz}, \mathrm{C}_{5} \mathrm{H}_{4} \mathrm{CH}_{2}\right), 25.4\left(\mathrm{~d},{ }^{1} J_{\mathrm{CP}}=14 \mathrm{~Hz}, \mathrm{CH}_{2} \mathrm{P}\right) .{ }^{31} \mathrm{P}$ NMR $(161.8 \mathrm{MHz}$, chloroform- $d$ ): $\delta-29.4$ (m). FT-IR/ATR: 3101 (w), 2931 (w), 2360 (w), 2304 (w), 1409 (w), 1187 (m), 1100 (m), 1040 (m), $997(\mathrm{~m}), 802(\mathrm{~s})$, and $683(\mathrm{~m}) \mathrm{cm}^{-1}$. UV-vis (tetrahydrofuran): $\lambda_{\max } 319 \mathrm{~nm}\left(\varepsilon=770 \mathrm{M}^{-1}\right.$ $\mathrm{cm}^{-1}$ ). Mass Spec. (EI, +ve mode): exact mass calculated for $\left[\mathrm{C}_{36} \mathrm{H}_{39} \mathrm{P}^{96} \mathrm{Ru}_{2}{ }^{102} \mathrm{Ru}\right]^{+}$: 795.9985; 
exact mass found: 795.9998; difference: 1.63 ppm. Anal. Calcd. (\%) for $\mathrm{C}_{36} \mathrm{H}_{39} \mathrm{PRu}_{3}$ : C, 53.65; H, 4.88. Found: C, 53.60; H, 4.81.

\section{Preparation of tertiary phosphine $10(1 \times \mathrm{Rc}, 2 \times \mathrm{Fc})$}

In a $25 \mathrm{~mL}$ grease-free Schlenk flask, secondary phosphine $7 \mathbf{b}(2.000 \mathrm{~g}, 4.366 \mathrm{mmol})$ was combined with vinylruthenocene $(0.375 \mathrm{~g}, 1.46 \mathrm{mmol})$ and AIBN $(0.012 \mathrm{~g}, 0.073 \mathrm{mmol})$ in $6 \mathrm{~mL}$ of dry tetrahydrofuran before it was allowed to stir for $16 \mathrm{~h}$ at $45{ }^{\circ} \mathrm{C}$ then $8 \mathrm{~h}$ at $65{ }^{\circ} \mathrm{C}$. The reaction flask was charged a second time with vinylruthenocene $(0.250 \mathrm{~g}, 0.972 \mathrm{mmol})$ and AIBN $(0.008 \mathrm{~g}, 0.05 \mathrm{mmol})$ and stirred for $16 \mathrm{~h}$ at $45^{\circ} \mathrm{C}$ then $8 \mathrm{~h}$ at $65{ }^{\circ} \mathrm{C}$. Vinylruthenocene $(0.165 \mathrm{~g}, 0.642 \mathrm{mmol})$ and AIBN $(0.005 \mathrm{~g}, 0.03 \mathrm{mmol})$ were added to the reaction flask for a third time and the orange solution was allowed to stir at $45^{\circ} \mathrm{C}$ for $16 \mathrm{~h}$, followed by stirring at 65 ${ }^{\circ} \mathrm{C}$ for $8 \mathrm{~h}$. Vinylruthenocene $(0.110 \mathrm{~g}, 0.428 \mathrm{mmol})$ and AIBN $(0.003 \mathrm{~g}, 0.02 \mathrm{mmol})$ were added to the reaction flask for a fourth time and the orange solution was allowed to stir at $45{ }^{\circ} \mathrm{C}$ for 16 $\mathrm{h}$, followed by stirring at $65{ }^{\circ} \mathrm{C}$ for $8 \mathrm{~h}$, and $85^{\circ} \mathrm{C}$ for $2 \mathrm{~h}$ before it was concentrated in vacuo. The oily orange solid was dissolved in dichloromethane and combined with celite before the resulting mixture was dried in vacuo and transferred to the top of a silica column [1.5" $\times 8$ ", treated with triethylamine $10 \%(\mathrm{v} / \mathrm{v})$ as described above] for subsequent purification by column chromatography using a gradient solvent strategy. Using $\mathrm{N}_{2}$ gas and a mixture of 99:1 hexanes:diethyl ether, unreacted secondary phosphine $\mathbf{7 b}$ was removed from the column $(0.380 \mathrm{~g}$ recovered). After removal of secondary phosphine $\mathbf{7 b}$, tertiary phosphine $\mathbf{1 0}$ was collected from the column by changing the elution solvent to $4: 1$ hexanes:diethyl ether $\left(R_{f}=0.47\right.$, untreated silica TLC plate). The solution containing tertiary phosphine $\mathbf{1 0}$ was concentrated in vacuo to yield an orange solid. Yield $=2.365$ g, 94\%. M.p. $135-137{ }^{\circ} \mathrm{C} .{ }^{1} \mathrm{H}$ NMR (599.5 MHz, chloroform- $d$ ): $\delta 4.56\left[\mathrm{t},{ }^{3} J_{\mathrm{HH}}=2 \mathrm{~Hz}, 2 \mathrm{H}, \beta-\mathrm{C}_{5} H_{4} \mathrm{R}(\mathrm{Ru})\right], 4.54\left[\mathrm{~s}, 5 \mathrm{H}, \mathrm{C}_{5} H_{5}(\mathrm{Ru})\right], 4.47\left[\mathrm{t},{ }^{3} J_{\mathrm{HH}}=\right.$ 
$\left.2 \mathrm{~Hz}, 2 \mathrm{H}, \alpha-\mathrm{C}_{5} H_{5} \mathrm{R}(\mathrm{Ru})\right], 4.13\left[\mathrm{~s}, 10 \mathrm{H}, \mathrm{C}_{5} H_{5}(\mathrm{Fe})\right], 4.11\left[\mathrm{t},{ }^{3} J_{\mathrm{HH}}=2 \mathrm{~Hz}, 4 \mathrm{H}, \beta-\mathrm{C}_{5} H_{4} \mathrm{R}(\mathrm{Fe})\right], 4.09$ $\left[\mathrm{t},{ }^{3} \mathrm{~J}_{\mathrm{HH}}=2 \mathrm{~Hz}, 4 \mathrm{H}, \alpha-\mathrm{C}_{5} \mathrm{H}_{5} \mathrm{R}(\mathrm{Fe})\right], 2.48\left[\mathrm{~m}, 4 \mathrm{H}, \mathrm{C}_{5} \mathrm{H}_{4} \mathrm{CH}_{2}(\mathrm{Fe})\right], 2.33\left[\mathrm{~m}, 2 \mathrm{H}, \mathrm{C}_{5} \mathrm{H}_{4} \mathrm{CH}_{2}(\mathrm{Ru})\right]$, $1.66\left[\mathrm{~m}, 4 \mathrm{H}, \mathrm{CH}_{2} \mathrm{P}(\mathrm{Fe})\right], 1.61\left[\mathrm{~m}, 2 \mathrm{H}, \mathrm{CH}_{2} \mathrm{P}(\mathrm{Ru})\right] .{ }^{13} \mathrm{C}\left\{{ }^{1} \mathrm{H}\right\}$ NMR (150.1 MHz, chloroform- $d$ ): $\delta$ $93.9\left[\mathrm{~d},{ }^{3} J_{\mathrm{CP}}=13 \mathrm{~Hz}\right.$, ipso- $\left.C_{5} \mathrm{H}_{4} \mathrm{R}(\mathrm{Ru})\right], 89.8\left[\mathrm{~d},{ }^{3} J_{\mathrm{CP}}=13 \mathrm{~Hz}\right.$, ipso- $\left.C_{5} \mathrm{H}_{4} \mathrm{R}(\mathrm{Fe})\right], 70.5[\mathrm{~s}, \beta$ $\left.C_{5} \mathrm{H}_{4} \mathrm{R}(\mathrm{Ru})\right], 70.5\left[\mathrm{~s}, C_{5} \mathrm{H}_{5}(\mathrm{Ru})\right], 69.4\left[\mathrm{~s}, \alpha-C_{5} \mathrm{H}_{4} \mathrm{R}(\mathrm{Ru})\right], 68.5\left[\mathrm{~s}, C_{5} \mathrm{H}_{5}(\mathrm{Fe})\right], 67.8[\mathrm{~s}, \quad \beta-$ $\left.C_{5} \mathrm{H}_{4} \mathrm{R}(\mathrm{Fe})\right], 67.3\left[\mathrm{~s}, \alpha-C_{5} \mathrm{H}_{4} \mathrm{R}(\mathrm{Fe})\right], 28.9\left[\mathrm{~d},{ }^{2} J_{\mathrm{CP}}=13 \mathrm{~Hz}, \mathrm{C}_{5} \mathrm{H}_{4} C \mathrm{CH}_{2}(\mathrm{Ru})\right], 28.5\left[\mathrm{~d},{ }^{2} J_{\mathrm{CP}}=13 \mathrm{~Hz}\right.$, $\left.\mathrm{C}_{5} \mathrm{H}_{4} \mathrm{CH}_{2}(\mathrm{Fe})\right], 26.1\left[\mathrm{~d},{ }^{1} J_{\mathrm{CP}}=16 \mathrm{~Hz}, \mathrm{CH}_{2} \mathrm{P}(\mathrm{Fe})\right], 25.5\left[\mathrm{~d},{ }^{1} J_{\mathrm{CP}}=15 \mathrm{~Hz}, C_{2} \mathrm{P}(\mathrm{Ru})\right] .{ }^{31} \mathrm{P} \mathrm{NMR}$ (161.8 MHz, chloroform- $d$ ): $\delta$-28.4 (m). FT-IR/ATR: 3101 (w), 2941 (w), 2915 (w), $1440(w)$, $1227(\mathrm{w}), 1104(\mathrm{~m}), 1000(\mathrm{~m}), 807(\mathrm{~s})$, and $667(\mathrm{w}) \mathrm{cm}^{-1}$. UV-vis (tetrahydrofuran): $\lambda_{\max } 324 \mathrm{~nm}$ $\left(\varepsilon=375 \mathrm{M}^{-1} \mathrm{~cm}^{-1}\right)$ and $436 \mathrm{~nm}\left(\varepsilon=205 \mathrm{M}^{-1} \mathrm{~cm}^{-1}\right)$. Mass Spec. (EI, +ve mode): exact mass calculated for $\left[\mathrm{C}_{36} \mathrm{H}_{39}{ }^{56} \mathrm{Fe}_{2} \mathrm{P}^{96} \mathrm{Ru}\right]^{+}:$710.0564; exact mass found: 710.0557; difference: -0.98 ppm. Anal. Calcd. (\%) for $\mathrm{C}_{36} \mathrm{H}_{39} \mathrm{Fe}_{2} \mathrm{PRu}$ : C, 60.44; H, 5.49. Found: C, 60.41; H, 5.49.

Preparation of secondary phosphine $11(1 \times \mathrm{Rc}, 1 \times \mathrm{Fc})$ and tertiary phosphine $12(2 \times \mathrm{Rc}$, $1 \times \mathbf{F c})$

In a $25 \mathrm{~mL}$ grease-free Schlenk flask, primary phosphine $7 \mathbf{a}(1 \times \mathrm{Fc})(1.000 \mathrm{~g}, 4.064 \mathrm{mmol})$ was combined with vinylruthenocene $(0.700 \mathrm{~g}, 2.72 \mathrm{mmol})$ and AIBN $(0.020 \mathrm{~g}, 0.12 \mathrm{mmol})$ in 6 $\mathrm{mL}$ of dry tetrahydrofuran before it was allowed to stir for $16 \mathrm{~h}$ at $45^{\circ} \mathrm{C}, 6 \mathrm{~h}$ at $65^{\circ} \mathrm{C}$, and $2 \mathrm{~h}$ at $85{ }^{\circ} \mathrm{C}$ and concentrated in vacuo. The oily orange solid was dissolved in dichloromethane and combined with celite before the resulting mixture was dried in vacuo and transferred to the top of a silica column $[1.5 " \times 8$ ", treated with triethylamine $10 \%(\mathrm{v} / \mathrm{v})$ as described above] for subsequent purification by column chromatography using a gradient solvent strategy (see below). Secondary phosphine $11(1 \times R c, 1 \times F c)$ 
Using $\mathrm{N}_{2}$ gas and hexanes as eluent, unreacted primary phosphine 7a $(0.450 \mathrm{~g})$ was removed from the column before the eluent was changed to a mixture of 99:1 hexanes:diethyl ether which removed secondary phosphine $\mathbf{1 1}$ from the column as a yellow band $\left(\mathrm{R}_{\mathrm{f}}=0.15\right.$, untreated silica TLC plate). The solution containing secondary phosphine $\mathbf{1 1}$ was concentrated in vacuo to yield an orange solid. Yield $=0.522$ g, 39\%. M.p. $76-78{ }^{\circ} \mathrm{C} .{ }^{1} \mathrm{H}$ NMR (599.5 MHz, chloroform- $d$ ): $\delta$ $4.54\left[\mathrm{t},{ }^{3} J_{\mathrm{HH}}=2 \mathrm{~Hz}, 2 \mathrm{H}, \beta-\mathrm{C}_{5} H_{4} \mathrm{R}(\mathrm{Ru})\right], 4.53\left[\mathrm{~s}, 5 \mathrm{H}, \mathrm{C}_{5} H_{5}(\mathrm{Ru})\right], 4.46\left[\mathrm{t},{ }^{3} J_{\mathrm{HH}}=2 \mathrm{~Hz}, 2 \mathrm{H}, \alpha-\right.$ $\left.\mathrm{C}_{5} H_{5} \mathrm{R}(\mathrm{Ru})\right], 4.12\left[\mathrm{~s}, 5 \mathrm{H}, \mathrm{C}_{5} H_{5}(\mathrm{Fe})\right], 4.08\left[\mathrm{t},{ }^{3} J_{\mathrm{HH}}=2 \mathrm{~Hz}, 2 \mathrm{H}, \beta-\mathrm{C}_{5} H_{4} \mathrm{R}(\mathrm{Fe})\right], 4.07\left[\mathrm{t},{ }^{3} J_{\mathrm{HH}}=2 \mathrm{~Hz}\right.$, $\left.2 \mathrm{H}, \alpha-\mathrm{C}_{5} H_{5} \mathrm{R}(\mathrm{Fe})\right], 3.16$ (d of quintets, ${ }^{1} J_{\mathrm{HP}}=201 \mathrm{~Hz},{ }^{3} J_{\mathrm{HH}}=7 \mathrm{~Hz}, 1 \mathrm{H}, \mathrm{PH}$ ), $2.52[\mathrm{~m}, 2 \mathrm{H}$, $\left.\mathrm{C}_{5} \mathrm{H}_{4} \mathrm{CH}_{2}(\mathrm{Fe})\right], 2.37\left[\mathrm{~m}, 2 \mathrm{H}, \mathrm{C}_{5} \mathrm{H}_{4} \mathrm{CH}_{2}(\mathrm{Ru})\right], 1.81 \quad\left[\mathrm{~m}, 2 \mathrm{H}, \mathrm{CH}_{2} \mathrm{PH}(\mathrm{Fe})\right], 1.69 \quad[\mathrm{~m}, 2 \mathrm{H}$, $\left.\mathrm{CH}_{2} \mathrm{PH}(\mathrm{Ru})\right] .{ }^{13} \mathrm{C}\left\{{ }^{1} \mathrm{H}\right\} \mathrm{NMR}(150.1 \mathrm{MHz}$, chloroform- $d): \delta 93.4\left[\mathrm{~d},{ }^{3} J_{\mathrm{CP}}=10 \mathrm{~Hz}\right.$, ipso$\left.C_{5} \mathrm{H}_{4} \mathrm{R}(\mathrm{Ru})\right], 89.3\left[\mathrm{~d},{ }^{3} J_{\mathrm{CP}}=9 \mathrm{~Hz}\right.$, ipso- $\left.C_{5} \mathrm{H}_{4} \mathrm{R}(\mathrm{Fe})\right], 70.5$ [s, $\left.\beta-C_{5} \mathrm{H}_{4} \mathrm{R}(\mathrm{Ru})\right], 70.4\left[\mathrm{~s}, C_{5} \mathrm{H}_{5}(\mathrm{Ru})\right]$, $69.4\left[\mathrm{~s}, \alpha-C_{5} \mathrm{H}_{4} \mathrm{R}(\mathrm{Ru})\right], 68.4\left[\mathrm{~s}, C_{5} \mathrm{H}_{5}(\mathrm{Fe})\right], 67.8\left[\mathrm{~s}, \beta-C_{5} \mathrm{H}_{4} \mathrm{R}(\mathrm{Fe})\right], 67.2\left[\mathrm{~s}, \alpha-C_{5} \mathrm{H}_{4} \mathrm{R}(\mathrm{Fe})\right], 28.4[\mathrm{~d}$, $\left.{ }^{2} J_{\mathrm{CP}}=10 \mathrm{~Hz}, \mathrm{C}_{5} \mathrm{H}_{4} C \mathrm{H}_{2}(\mathrm{Ru})\right], 28.1\left[\mathrm{~d},{ }^{2} J_{\mathrm{CP}}=10 \mathrm{~Hz}, \mathrm{C}_{5} \mathrm{H}_{4} C \mathrm{H}_{2}(\mathrm{Fe})\right], 22.3\left[\mathrm{~d},{ }^{1} J_{\mathrm{CP}}=10 \mathrm{~Hz}\right.$, $\left.\mathrm{CH}_{2} \mathrm{PH}(\mathrm{Fe})\right], 21.8\left[\mathrm{~d},{ }^{1} J_{\mathrm{CP}}=11 \mathrm{~Hz}, C \mathrm{H}_{2} \mathrm{PH}(\mathrm{Ru})\right] .{ }^{31} \mathrm{P}$ NMR $(161.8 \mathrm{MHz}$, chloroform- $d): \delta-68.9$ $\left(\mathrm{d}\right.$ of $\left.\mathrm{m},{ }^{1} J_{\mathrm{PH}}=200 \mathrm{~Hz}\right)$. FT-IR/ATR: $3096(\mathrm{w}), 2915(\mathrm{w}), 2254(\mathrm{w}), 1442(\mathrm{w}), 1100(\mathrm{w}), 1000$ (w), and 805 (s) $\mathrm{cm}^{-1}$. UV-vis (tetrahydrofuran): $\lambda_{\max } 324 \mathrm{~nm}\left(\varepsilon=300 \mathrm{M}^{-1} \mathrm{~cm}^{-1}\right)$ and $436 \mathrm{~nm}(\varepsilon$ $=105 \mathrm{M}^{-1} \mathrm{~cm}^{-1}$ ). Mass Spec. (EI, +ve mode): exact mass calculated for $\left[\mathrm{C}_{24} \mathrm{H}_{27}{ }^{56} \mathrm{FeP}^{102} \mathrm{Ru}\right]^{+}$: 504.0243; exact mass found: 504.0248; difference: $0.99 \mathrm{ppm}$. Anal. Calcd. (\%) for $\mathrm{C}_{24} \mathrm{H}_{27} \mathrm{FePRu}: \mathrm{C}, 57.27 ; \mathrm{H}, 5.41$. Found: C, 57.31; H, 5.40.

Tertiary phosphine $12(2 \times R c, 1 \times F c)$

After removal of secondary phosphine 11, tertiary phosphine $\mathbf{1 2}$ was collected from the column by changing the elution solvent to a mixture of 95:5 hexanes:diethyl ether $\left(R_{f}=0.46\right.$, untreated silica TLC plate). The solution containing tertiary phosphine $\mathbf{1 2}$ was concentrated in 
vacuo to yield a yellow solid. Yield $=0.436$ g, $42 \%$. M.p. $106-108{ }^{\circ} \mathrm{C} .{ }^{1} \mathrm{H}$ NMR $(599.5 \mathrm{MHz}$, chloroform- $d$ ): $\delta 4.55\left[\mathrm{t},{ }^{3} J_{\mathrm{HH}}=2 \mathrm{~Hz}, 4 \mathrm{H}, \beta-\mathrm{C}_{5} H_{4} \mathrm{R}(\mathrm{Ru})\right], 4.54\left[\mathrm{~s}, 10 \mathrm{H}, \mathrm{C}_{5} H_{5}(\mathrm{Ru})\right], 4.47\left[\mathrm{t},{ }^{3} J_{\mathrm{HH}}=\right.$ $\left.4 \mathrm{~Hz}, 4 \mathrm{H}, \alpha-\mathrm{C}_{5} H_{5} \mathrm{R}(\mathrm{Ru})\right], 4.12\left[\mathrm{~s}, 5 \mathrm{H}, \mathrm{C}_{5} H_{5}(\mathrm{Fe})\right], 4.11\left[\mathrm{t},{ }^{3} J_{\mathrm{HH}}=2 \mathrm{~Hz}, 2 \mathrm{H}, \beta-\mathrm{C}_{5} H_{4} \mathrm{R}(\mathrm{Fe})\right], 4.08[\mathrm{t}$, $\left.{ }^{3} J_{\mathrm{HH}}=2 \mathrm{~Hz}, 2 \mathrm{H}, \alpha-\mathrm{C}_{5} H_{5} \mathrm{R}(\mathrm{Fe})\right], 2.47\left[\mathrm{~m}, 2 \mathrm{H}, \mathrm{C}_{5} \mathrm{H}_{4} \mathrm{CH}_{2}(\mathrm{Fe})\right], 2.32\left[\mathrm{~m}, 4 \mathrm{H}, \mathrm{C}_{5} \mathrm{H}_{4} \mathrm{CH}_{2}(\mathrm{Ru})\right], 1.64$ [m, 2H, CH$\left.H_{2} \mathrm{P}(\mathrm{Fe})\right], 1.60\left[\mathrm{~m}, 4 \mathrm{H}, \mathrm{CH}_{2} \mathrm{P}(\mathrm{Ru})\right] .{ }^{13} \mathrm{C}\left\{{ }^{1} \mathrm{H}\right\} \mathrm{NMR}(150.1 \mathrm{MHz}$, chloroform- $d$ ): $\delta 93.9$ $\left[\mathrm{d},{ }^{3} J_{\mathrm{CP}}=13 \mathrm{~Hz}\right.$, ipso- $\left.C_{5} \mathrm{H}_{4} \mathrm{R}(\mathrm{Ru})\right], 89.8\left[\mathrm{~d},{ }^{3} J_{\mathrm{CP}}=13 \mathrm{~Hz}\right.$, ipso- $\left.C_{5} \mathrm{H}_{4} \mathrm{R}(\mathrm{Fe})\right], 70.5[\mathrm{~s}, \beta$ $\left.C_{5} \mathrm{H}_{4} \mathrm{R}(\mathrm{Ru})\right], 70.4\left[\mathrm{~s}, C_{5} \mathrm{H}_{5}(\mathrm{Ru})\right], 69.4 \quad\left[\mathrm{~s}, \alpha-C_{5} \mathrm{H}_{4} \mathrm{R}(\mathrm{Ru})\right], 68.5\left[\mathrm{~s}, C_{5} \mathrm{H}_{5}(\mathrm{Fe})\right], 67.8 \quad[\mathrm{~s}, \beta-$ $\left.C_{5} \mathrm{H}_{4} \mathrm{R}(\mathrm{Fe})\right], 67.2\left[\mathrm{~s}, \alpha-C_{5} \mathrm{H}_{4} \mathrm{R}(\mathrm{Fe})\right], 28.8\left[\mathrm{~d},{ }^{2} J_{\mathrm{CP}}=14 \mathrm{~Hz}, \mathrm{C}_{5} \mathrm{H}_{4} C \mathrm{CH}_{2}(\mathrm{Ru})\right], 28.4\left[\mathrm{~d},{ }^{2} J_{\mathrm{CP}}=13 \mathrm{~Hz}\right.$, $\left.\mathrm{C}_{5} \mathrm{H}_{4} \mathrm{CH}_{2}(\mathrm{Fe})\right], 26.0\left[\mathrm{~d},{ }^{1} J_{\mathrm{CP}}=15 \mathrm{~Hz}, C \mathrm{H}_{2} \mathrm{P}(\mathrm{Fe})\right], 25.5\left[\mathrm{~d},{ }^{1} J_{\mathrm{CP}}=15 \mathrm{~Hz}, C_{2} \mathrm{P}(\mathrm{Ru})\right] .{ }^{31} \mathrm{P} \mathrm{NMR}$ (161.8 MHz, chloroform- $d$ ): $\delta$-28.9 (m). FT-IR/ATR: 3101 (w), 2928 (w), 1411 (w), $1229(w)$, $1100(\mathrm{~m}), 998(\mathrm{~m}), 805(\mathrm{~s})$, and $666(\mathrm{w}) \mathrm{cm}^{-1}$. UV-vis (tetrahydrofuran): $\lambda_{\max } 322 \mathrm{~nm}(\varepsilon=495$ $\left.\mathrm{M}^{-1} \mathrm{~cm}^{-1}\right)$ and $438 \mathrm{~nm}\left(\varepsilon=95 \mathrm{M}^{-1} \mathrm{~cm}^{-1}\right)$. Mass Spec. (EI, +ve mode): exact mass calculated for $\left[\mathrm{C}_{36} \mathrm{H}_{39}{ }^{56} \mathrm{FeP}^{96} \mathrm{Ru}^{99} \mathrm{Ru}\right]^{+}:$753.0274; exact mass found: 753.0274; difference: 0 ppm. Anal. Calcd. (\%) for $\mathrm{C}_{36} \mathrm{H}_{39} \mathrm{FePRu} \mathrm{P}_{2}$ : C, 56.84; H, 5.17. Found: C, 56.88; H, 5.16.

\section{ASSOCIATED CONTENT}

Supporting Information. Additional NMR and UV-vis absorption spectra, cyclic voltammograms, and solid-state structures. This material is available free of charge via the Internet at http://pubs.acs.org.

\section{AUTHOR INFORMATION}

\section{Corresponding Author}

*E-mail: joe.gilroy@uwo.ca 


\section{Notes}

The authors declare no competing financial interest.

\section{ACKNOWLEDGEMENTS}

We would like to thank the University of Western Ontario, the Natural Science and Engineering Research Council (NSERC) of Canada (E.R.G., P.J.R., J.B.G.: DG, 341667, 311921, 435675; S.M.B.: CGS-M, CGS-D scholarships), and the Ontario Ministry of Research and Innovation (J.B.G.: ERA, ER14-10-147) for funding this work. We also thank Cytec Canada Inc. for providing $\mathrm{PH}_{3}$ and expertise surrounding its safe usage. Finally, we acknowledge Dr. Jacquelyn T. Price and Ethan R. Sauvé for their contributions to this work.

\section{REFERENCES}

(1) Selected reviews and books: (a) Tolman, C. A. Chem. Rev. 1977, 77, 313-348. (b) Erre, G.; Enthaler, S.; Junge, K.; Gladiali, S.; Beller, M. Coord. Chem. Rev. 2008, 252, 471-491. (c) Shaughnessy, K. H. Chem. Rev. 2009, 109, 643-710. (d) Kamer, P. C. J.; van Leeuwen, P. W. N. M. Phosphorus(III) Ligands in Homogeneous Catalysis: Design and Synthesis; WileyBlackwell: Oxford, 2012. (e) Burt, J.; Levason, W.; Reid, G. Coord. Chem. Rev. 2014, 260, 65115. (f) Chikkali, S. H.; van der Vlugt, J. I.; Reek, J. N. H. Coord. Chem. Rev. 2014, 262, 1-15. (g) Genet, J.-P.; Ayad, T.; Ratovelomanana-Vidal, V. Chem. Rev. 2014, 114, 2824-2880. (h) Nell, B. P.; Tyler, D. R. Coord. Chem. Rev. 2014, 279, 23-42. (i) Stephan, D. W. Acc. Chem. Res. 2015, 48, 306-316. (j) Voituriez, A.; Marinetti, A.; Gicquel, M. Synlett 2015, 26, 142-166.

(2) Selected examples: (a) Annen, S. P.; Bambagioni, V.; Bevilacqua, M.; Filippi, J.; Marchionni, A.; Oberhauser, W.; Schönberg, H.; Vizza, F.; Bianchini, C.; Grützmacher, H. 
Angew. Chem. Int. Ed. 2010, 49, 7229-7233. (b) Anderson, J. S.; Rittle, J.; Peters, J. C. Nature 2013, 501, 84-87. (c) Dobereiner, G. E.; Yuan, J.; Schrock, R. R.; Goldman, A. S.; Hackenberg, J. D. J. Am. Chem. Soc. 2013, 135, 12572-12575. (d) Kawaguchi, S.-i.; Minamida, Y.; Ohe, T.; Nomoto, A.; Sonoda, M.; Ogawa, A. Angew. Chem. Int. Ed. 2013, 52, 1748-1752. (e) Lavallo, V.; Wright, J. H.; Tham, F. S.; Quinlivan, S. Angew. Chem. Int. Ed. 2013, 52, 3172-3176. (f) Cheng, C.; Hartwig, J. F. J. Am. Chem. Soc. 2014, 136, 12064-12072. (g) Kang, P.; Zhang, S.; Meyer, T. J.; Brookhart, M. Angew. Chem. Int. Ed. 2014, 53, 8709-8713. (h) Zhang, X.-N.; Chen, G.-Q.; Tang, X.-Y.; Wei, Y.; Shi, M. Angew. Chem. Int. Ed. 2014, 53, 10768-10773. (i) Zhu, Y.; Buchwald, S. L. J. Am. Chem. Soc. 2014, 136, 4500-4503. (j) Yan, X.; Cook, T. R.; Wang, P.; Huang, F.; Stang, P. J. Nat. Chem. 2015, 7, 342-348. (k) Zhao, D.; Neubauer, T. M.; Feringa, B. L. Nat. Commun. 2015, 6, 6652.

(3) Selected reviews: (a) Katti, K. V.; Gali, H.; Smith, C. J.; Berning, D. E. Acc. Chem. Res. 1999, 32, 9-17. (b) Brynda, M. Coord. Chem. Rev. 2005, 249, 2013-2034. (c) Fleming, J. T.; Higham, L. J. Coord. Chem. Rev. 2015, 297-298, 127-145.

(4) Selected examples: (a) Yoshifuji, M.; Shibayama, K.; Inamoto, N.; Matsushita, T.; Nishimoto, K. J. Am. Chem. Soc. 1983, 105, 2495-2497. (b) Ramakrishnan, G.; Jouaiti, A.; Geoffroy, M.; Bernardinelli, G. J. Phys. Chem. 1996, 100, 10861-10868. (c) Smith, C. J.; Reddy, V. S.; Karra, S. R.; Katti, K. V.; Barbour, L. J. Inorg. Chem. 1997, 36, 1786-1791. (d) Prabhu, K. R.; Pillarsetty, N.; Gali, H.; Katti, K. V. J. Am. Chem. Soc. 2000, 122, 1554-1555. (e) Twamley, B.; Hwang, C.-S.; Hardman, N. J.; Power, P. P. J. Organomet. Chem. 2000, 609, 152-160. (f) Henderson, W.; Alley, S. R. J. Organomet. Chem. 2002, 656, 120-128. (g) Downard, A. J.; Goodwin, N. J.; Henderson, W. J. Organomet. Chem. 2003, 676, 62-72. (h) Hiney, R. M.; Higham, L. J.; Müller-Bunz, H.; Gilheany, D. G. Angew. Chem. Int. Ed. 2006, 45, 
7248-7251. (i) Barder, T. E.; Buchwald, S. L. J. Am. Chem. Soc. 2007, 129, 5096-5101. (j) Kalio, R.; Lönnecke, P.; Hey-Hawkins, E. J. Organomet. Chem. 2008, 693, 590-600. (k) Stewart, B.; Harriman, A.; Higham, L. J. Organometallics 2011, 30, 5338-5343. (1) Davies, L. H.; Stewart, B.; Harrington, R. W.; Clegg, W.; Higham, L. J. Angew. Chem. Int. Ed. 2012, 51, 4921-4924. (m) Rabiee Kenaree, A.; Berven, B. M.; Ragogna, P. J.; Gilroy, J. B. Chem. Commun. 2014, 50, 10714-10717. (n) Asamizu, T.; Henderson, W.; Nicholson, B. K.; HeyHawkins, E. Inorg. Chim. Acta 2014, 414, 181-190. (o) Guterman, R.; Rabiee Kenaree, A.; Gilroy, J. B.; Gillies, E. R.; Ragogna, P. J. Chem. Mater. 2015, 27, 1412-1419.

(5) Selected reviews: (a) Colacot, T. J. Chem. Rev. 2003, 103, 3101-3118. (b) Atkinson, R. C. J.; Gibson, V. C.; Long, N. J. Chem. Soc. Rev. 2004, 33, 313-328. (c) Gómez Arrayás, R.; Adrio, J.; Carretero, J. C. Angew. Chem. Int. Ed. 2006, 45, 7674-7715. (d) Toma, Š.; Csizmadiová, J.; Mečiarová, M.; Šebesta, R. Dalton Trans. 2014, 43, 16557-16579.

(6) Recent examples: (a) Green, R. A.; Hartwig, J. F. Org. Lett. 2014, 16, 4388-4391. (b) Cowie, B. E.; Tsao, F. A.; Emslie, D. J. H. Angew. Chem. Int. Ed. 2015, 54, 2165-2169. (c) Gan, L.; Groy, T. L.; Tarakeshwar, P.; Mazinani, S. K. S.; Shearer, J.; Mujica, V.; Jones, A. K. J. Am. Chem. Soc. 2015, 137, 1109-1115. (d) Škoch, K.; Císařová, I.; Štěpnička, P. Organometallics 2015, 34, 1942-1956. (e) Brosmer, J. L.; Diaconescu, P. L. Organometallics 2015, 34, $2567-2572$.

(7) Selected examples: (a) Huber, D. P.; Kehr, G.; Bergander, K.; Fröhlich, R.; Erker, G.; Tanino, S.; Ohki, Y.; Tatsumi, K. Organometallics 2008, 27, 5279-5284. (b) Ramos, A.; Lough, A. J.; Stephan, D. W. Chem. Commun. 2009, 1118-1120. (c) Wang, X.; Kehr, G.; Daniliuc, C. G.; Erker, G. J. Am. Chem. Soc. 2014, 136, 3293-3303. 
(8) Selected examples: (a) Mizuta, T.; Imamura, Y.; Miyoshi, K. J. Am. Chem. Soc. 2003, 125, 2068-2069. (b) Patra, S. K.; Whittell, G. R.; Nagiah, S.; Ho, C.-L.; Wong, W.-Y.; Manners, I. Chem. Eur. J. 2010, 16, 3240-3250.

(9) Selected examples: (a) Wei, B.; Li, S.; Lee, H. K.; Hor, T. S. A. J. Organomet. Chem. 1997, 527, 133-136. (b) Swartz, B. D.; Nataro, C. Organometallics 2005, 24, 2447-2451. (c) Polukeev, A. V.; Petrovskii, P. V.; Peregudov, A. S.; Ezernitskaya, M. G.; Koridze, A. A. Organometallics 2013, 32, 1000-1015. (d) Fourie, E.; van Rensburg, J. M. J.; Swarts, J. C. J. Organomet. Chem. 2014, 754, 80-87.

(10) (a) Rauhut, M. M.; Currier, H. A.; Semsel, A. M.; Wystrach, V. P. J. Org. Chem. 1961, 26, 5138-5145. (b) Obata, T.; Kobayashi, E.; Aoshima, S.; Furukawa, J. Polym. J. 1993, 25, 1039_ 1048.

(11) Gritzner, G.; Kůta, J. Electrochim. Acta 1984, 29, 869-873.

(12) Connelly, N. G.; Geiger, W. E. Chem. Rev. 1996, 96, 877-910.

(13) (a) Morrison, W. H., Jr.; Hendrickson, D. N. Inorg. Chem. 1972, 11, 2912-2917. (b)

Denisovich, L. I.; Zakurin, N. V.; Bezrukova, A. A.; Gubin, S. P. J. Organomet. Chem. 1974, 81, 207-216.

(14) Russell, A. D.; Gilroy, J. B.; Lam, K.; Haddow, M. F.; Harvey, J. N.; Geiger, W. E.; Manners, I. Chem. Eur. J. 2014, 20, 16216-16227.

(15) Hashidzume, K.; Tobita, H.; Ogino, H. Organometallics 1995, 14, 1187-1194.

(16) (a) Sohn, Y. S.; Schlueter, A. W.; Hendrickson, D. N.; Gray, H. B. Inorg. Chem. 1974, 13, 301-304. (b) Smith, T. P.; Kwan, K. S.; Taube, H.; Bino, A.; Cohen, S. Inorg. Chem. 1984, 23, $1943-1945$.

(17) Geiger, W. E.; Barrière, F. Acc. Chem. Res. 2010, 43, 1030-1039. 
(18) (a) Trupia, S.; Nafady, A.; Geiger, W. E. Inorg. Chem. 2003, 42, 5480-5482. (b) Swarts, J. C.; Nafady, A.; Roudebush, J. H.; Trupia, S.; Geiger, W. E. Inorg. Chem. 2009, 48, 2156-2165.

(c) Erhard, M.; Lam, K.; Haddow, M.; Whittell, G. R.; Geiger, W. E.; Manners, I. Polymer. Chem. 2014, 5, 1264-1274.

(19) Russell, A. D.; Gilroy, J. B.; Lam, K.; Haddow, M. F.; Harvey, J. N.; Geiger, W. E.; Manners, I. Chem. Eur. J. 2012, 18, 8000-8003.

(20) Aranzaes, J. R.; Daniel, M.-C.; Astruc, D. Can. J. Chem. 2006, 84, 288-299.

(21) Seibert, A. R.; Cain, M. F.; Glueck, D. S.; Nataro, C. J. Organomet. Chem. 2011, 696, $2259-2262$.

(22) Sanders, R.; Mueller-Westerhoff, U. T. J. Organomet. Chem. 1996, 512, 219-224.

(23) Gallei, M.; Klein, R.; Rehahn, M. Macromolecules 2010, 43, 1844-1854.

(24) Bruker-AXS, SAINT version 2013.8, 2013, Bruker-AXS, Madison, WI 53711, USA.

(25) Bruker-AXS, SADABS version 2012.1, 2012, Bruker-AXS, Madison, WI 53711, USA.

(26) Bruker-AXS, TWINABS version 2012.1, 2012, Bruker-AXS, Madison, WI 53711, USA.

(27) Sheldrick, G. Acta Crystallogr. 2015, A71, 3-8.

(28) Sheldrick, G. Acta Crystallogr. 2008, A64, 112-122.

(29) Rausch, M. D.; Siegel, A. J. Organomet. Chem. 1968, 11, 317-324. 


\title{
Supporting Information
}

\section{Synthesis and Characterization of a Family of Air-Stable \\ Ferrocene- and Ruthenocene-Containing Primary, \\ Secondary, and Tertiary Phosphines}

\author{
Amir Rabiee Kenaree, ${ }^{a, b}$ Tyler J. Cuthbert, ${ }^{a, b}$ Stephanie M. Barbon, ${ }^{a, b}$ Paul D. Boyle, ${ }^{a}$ \\ Elizabeth R. Gillies, ${ }^{a, b, c}$ Paul J. Ragogna, ${ }^{a, b}$ and Joe B. Gilroy**,b
}

\begin{abstract}
${ }^{a}$ Department of Chemistry and ${ }^{b}$ The Centre for Advanced Materials and Biomaterials Research (CAMBR), The University of Western Ontario, 1151 Richmond St. N., London, Ontario, Canada N6A 5B7. ' Department of Chemical and Biochemical Engineering, The University of Western Ontario, 1151 Richmond St. N., London, Ontario, Canada N6A 5B9. Phone: +1-519-661-2111 ext. 81561, E-mail: joe.gilroy@uwo.ca.
\end{abstract}

\section{Table of Contents}

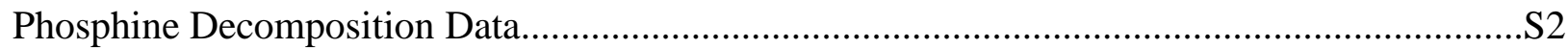

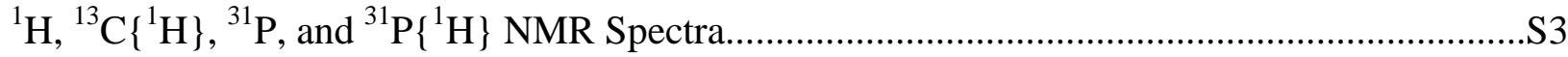

X-ray Diffraction Data Collection and Refinement Details..............................................S12

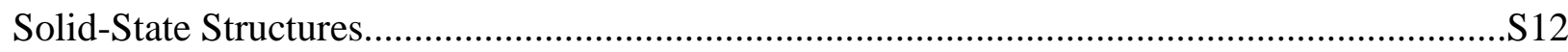

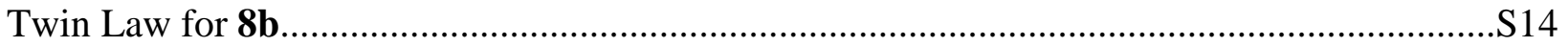

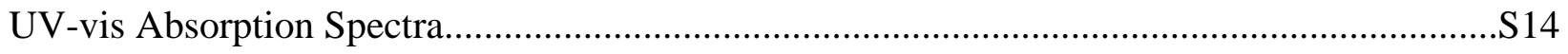

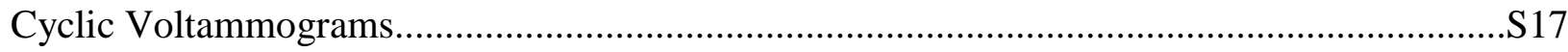

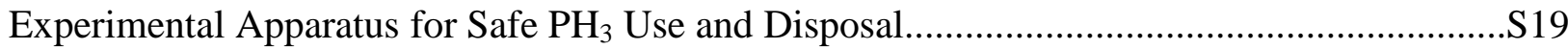




\section{Stability Studies}

Table S1. Degradation of primary, secondary, and tertiary phosphines $7 \mathbf{a}-\mathbf{c}, \mathbf{8 a}-\mathbf{c}, \mathbf{1 0}, \mathbf{1 1}$, and 12 in solutions exposed to air.

\begin{tabular}{lc}
\hline \multicolumn{1}{c}{ Compound } & Percentage conversion to phosphine oxide after 1 week $(\mathbf{1 6 8} \mathbf{~ h})^{\boldsymbol{a}}$ \\
\hline Primary Phosphines & 0 \\
$\mathbf{7 a}(1 \times \mathrm{Fc})$ & 6.3 \\
$\mathbf{8 a}(1 \times \mathrm{Rc})$ & 1.8 \\
\hline Secondary Phosphines & 0 \\
$\mathbf{7 b}(2 \times \mathrm{Fc})$ & 2.9 \\
$\mathbf{1 1}(1 \times \mathrm{Rc}, 1 \times \mathrm{Fc})$ & 2.9 \\
$\mathbf{8 b}(2 \times \mathrm{Rc})$ & 0.6 \\
\hline Tertiary Phosphines & 3.8 \\
$\mathbf{7 c}(3 \times \mathrm{Fc})$ & 7.5 \\
$\mathbf{1 0}(1 \times \mathrm{Rc}, 2 \times \mathrm{Fc})$ & \\
$\mathbf{1 2}(2 \times \mathrm{Rc}, 1 \times \mathrm{Fc})$ & \\
$\mathbf{8 c}(3 \times \mathrm{Rc})$ & \\
\hline ata based on ${ }^{31} \mathrm{P} \mathrm{NMR}$ integrations collected for $75 \mathrm{mM}$ solutions of phosphines prepared \\
ing dry $\mathrm{CDCl}{ }_{3}$ in air. For the duration of the experiment the samples were stored in capped \\
MR tubes under ambient conditions on the laboratory bench. No precautions were taken to \\
mit exposure to light or air.
\end{tabular}




\section{NMR Spectra}

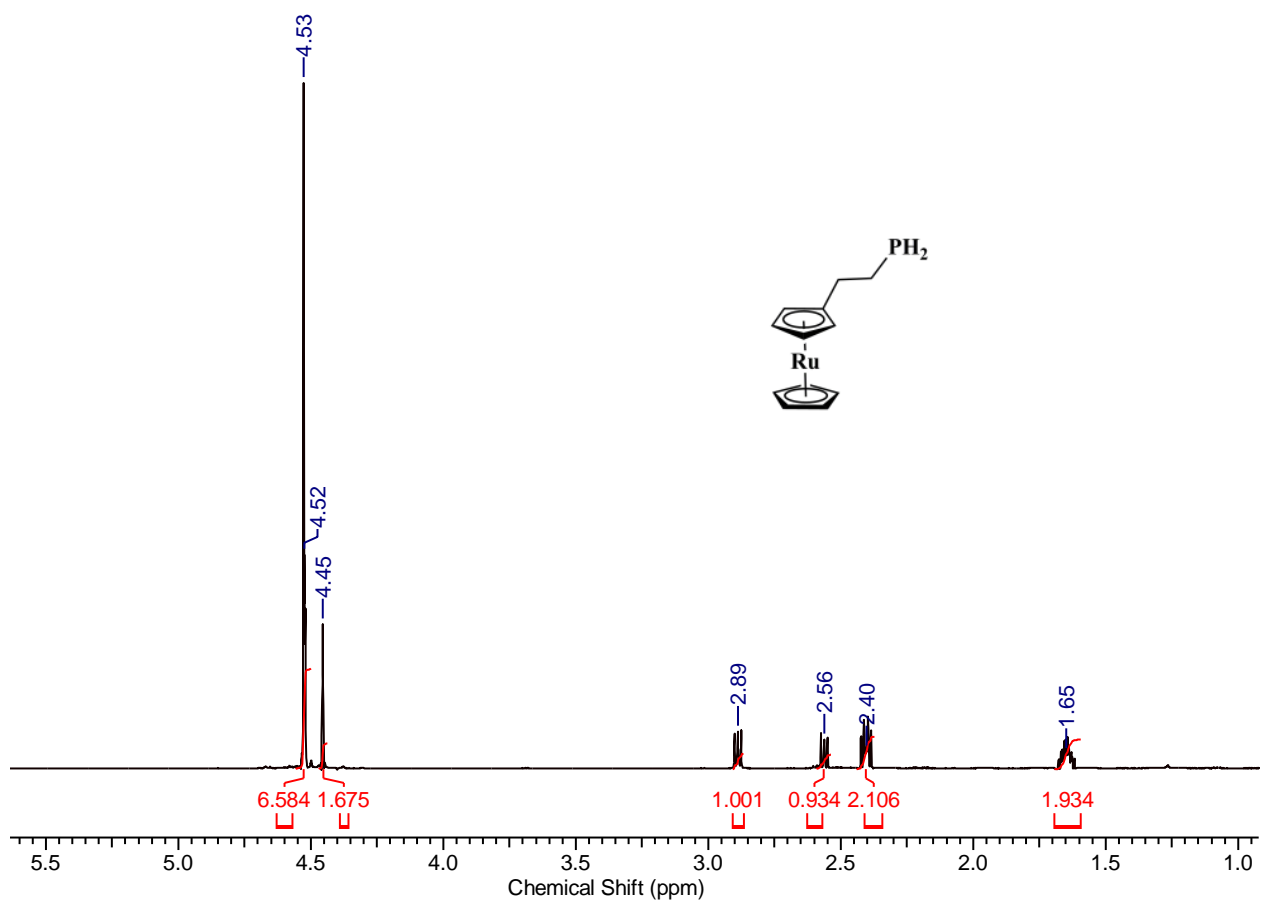

Figure S1. ${ }^{1} \mathrm{H}$ NMR spectrum of primary phosphine 8a in $\mathrm{CDCl}_{3}$.

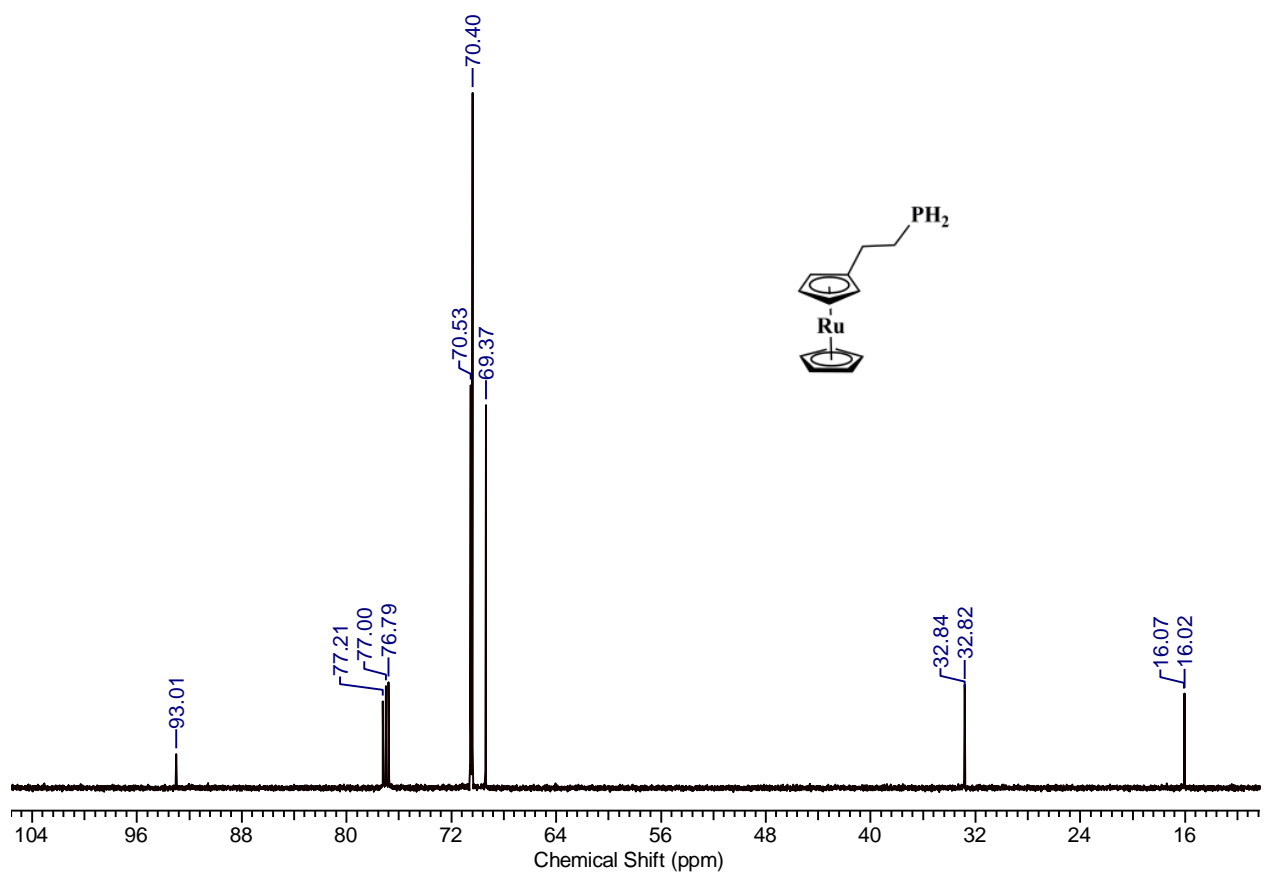

Figure S2. ${ }^{13} \mathrm{C}\left\{{ }^{1} \mathrm{H}\right\}$ NMR spectrum of primary phosphine 8a in $\mathrm{CDCl}_{3}$. 


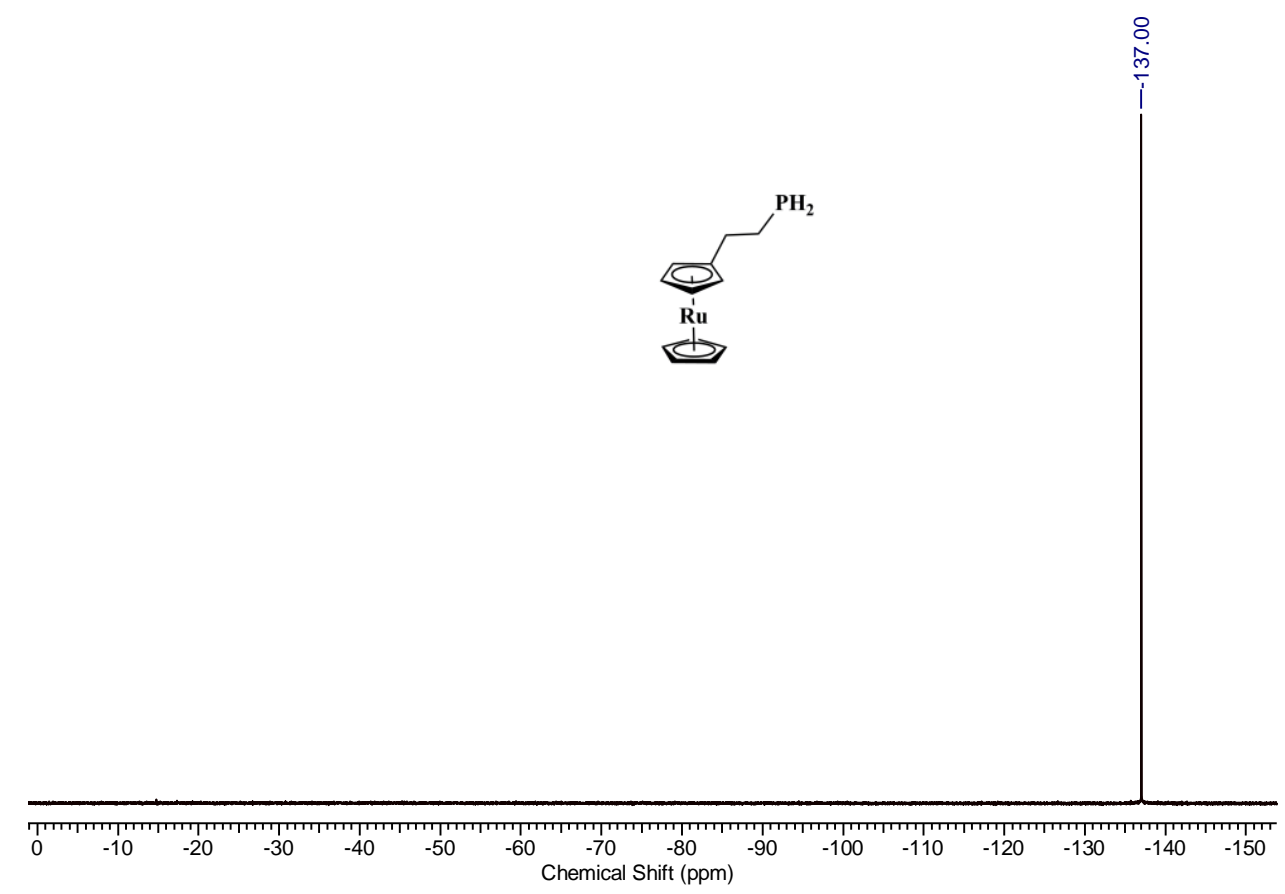

Figure S3. ${ }^{31} \mathrm{P}\left\{{ }^{1} \mathrm{H}\right\}$ NMR spectrum of primary phosphine $8 \mathbf{a}$ in $\mathrm{CDCl}_{3}$.

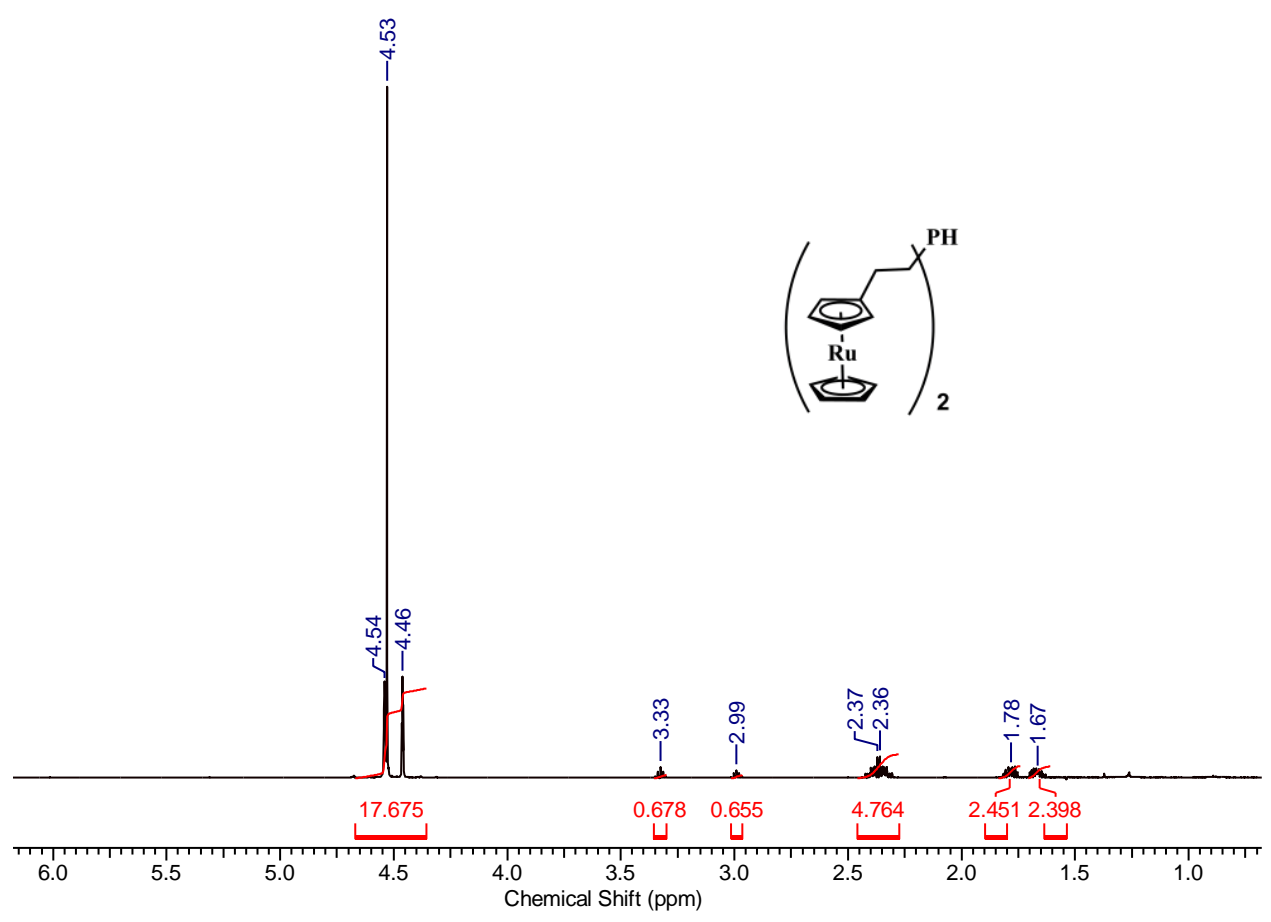

Figure S4. ${ }^{1} \mathrm{H}$ NMR spectrum of secondary phosphine $\mathbf{8 b}$ in $\mathrm{CDCl}_{3}$. 


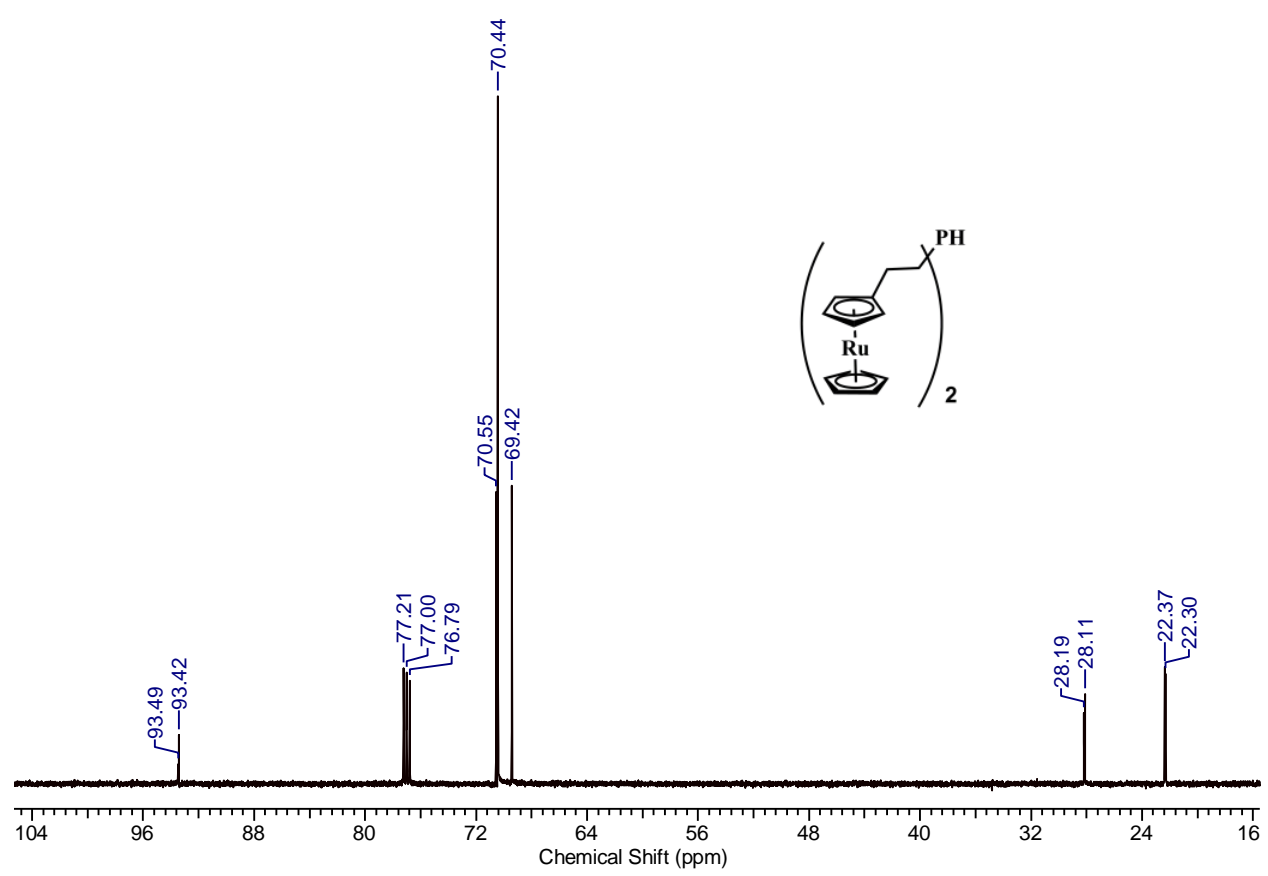

Figure S5. ${ }^{13} \mathrm{C}\left\{{ }^{1} \mathrm{H}\right\}$ NMR spectrum of secondary phosphine $\mathbf{8 b}$ in $\mathrm{CDCl}_{3}$.

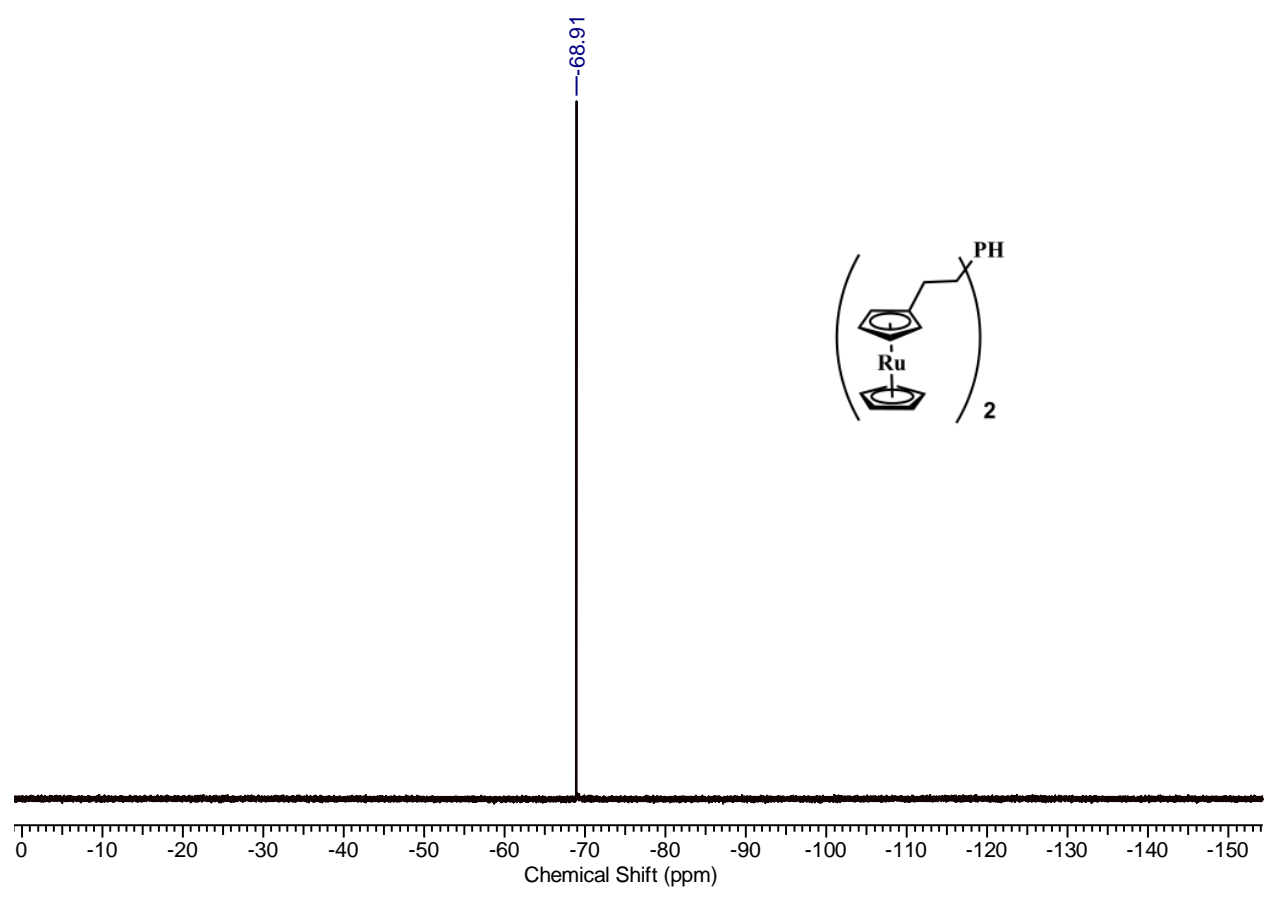

Figure S6. ${ }^{31} \mathrm{P}\left\{{ }^{1} \mathrm{H}\right\}$ NMR spectrum of secondary phosphine $\mathbf{8 b}$ in $\mathrm{CDCl}_{3}$. 


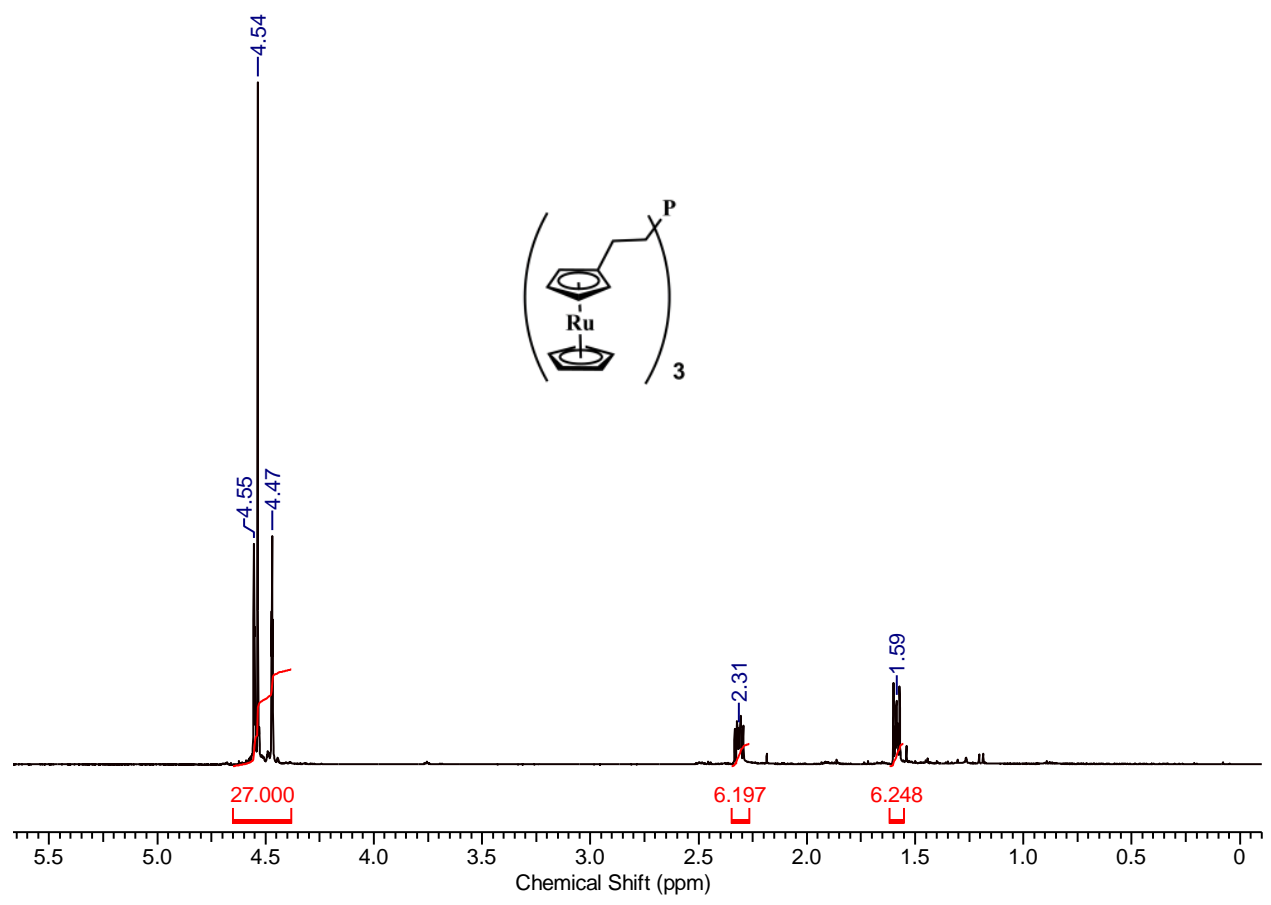

Figure S7. ${ }^{1} \mathrm{H}$ NMR spectrum of tertiary phosphine $8 \mathbf{c}$ in $\mathrm{CDCl}_{3}$.

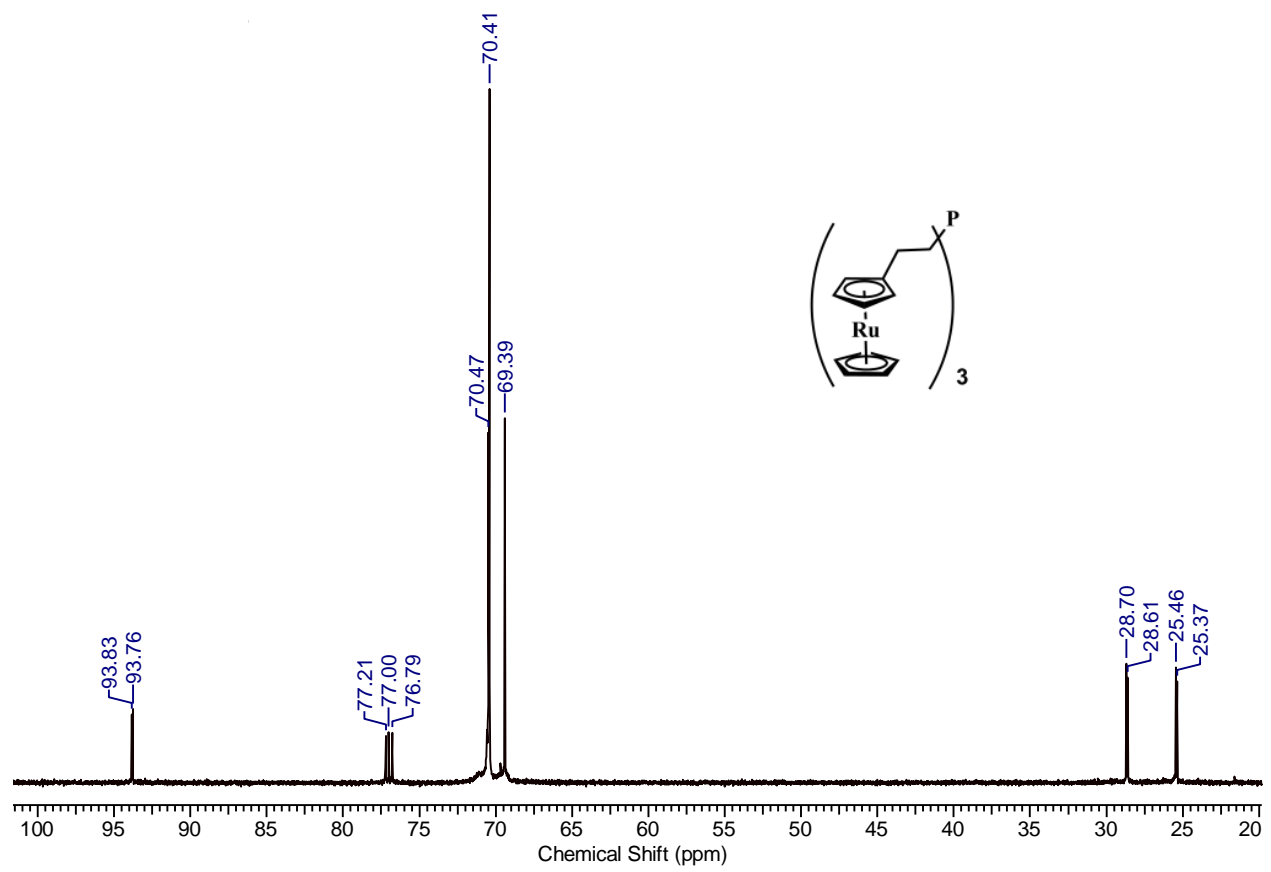

Figure S8. ${ }^{13} \mathrm{C}\left\{{ }^{1} \mathrm{H}\right\}$ NMR spectrum of tertiary phosphine 8c in $\mathrm{CDCl}_{3}$. 


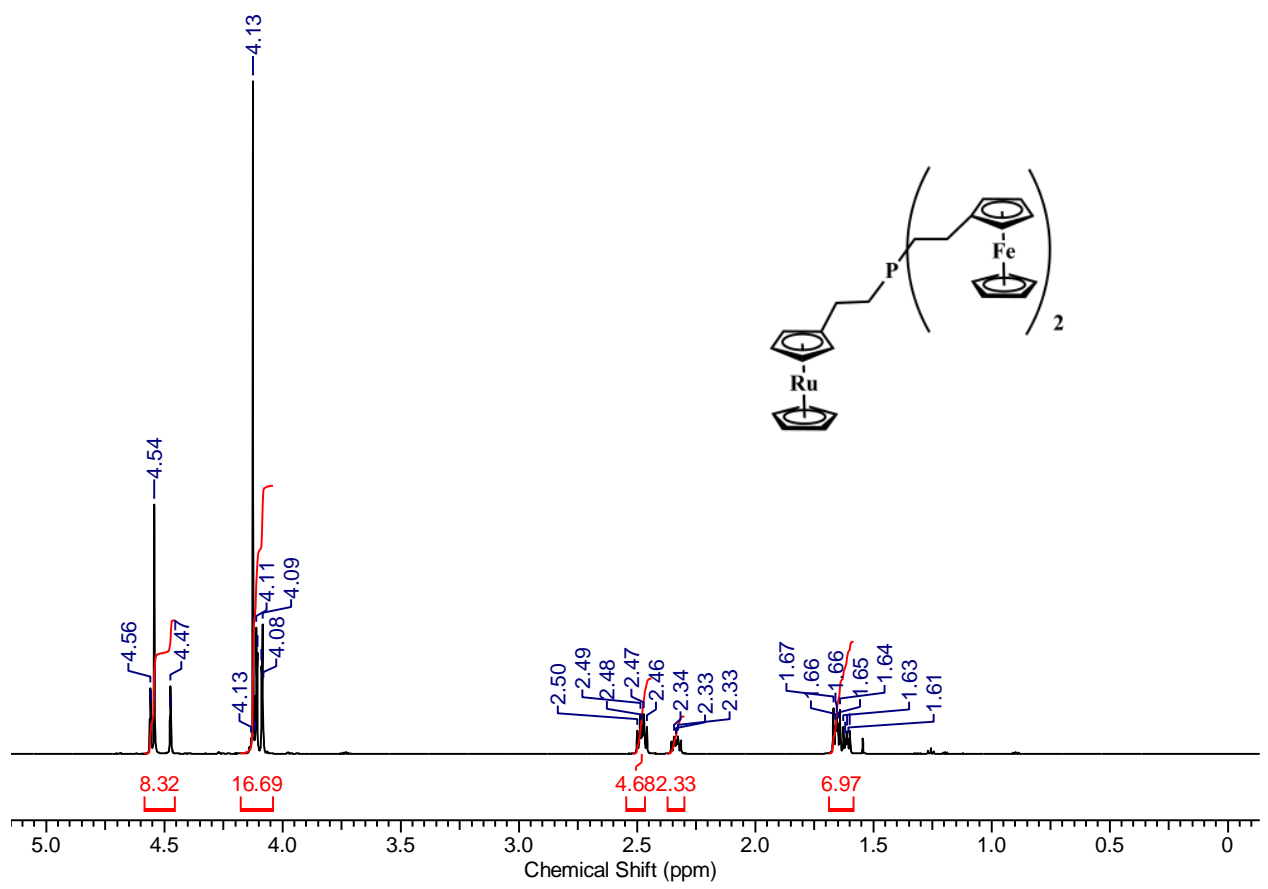

Figure S9. ${ }^{1} \mathrm{H}$ NMR spectrum of tertiary phosphine $\mathbf{1 0}$ in $\mathrm{CDCl}_{3}$.

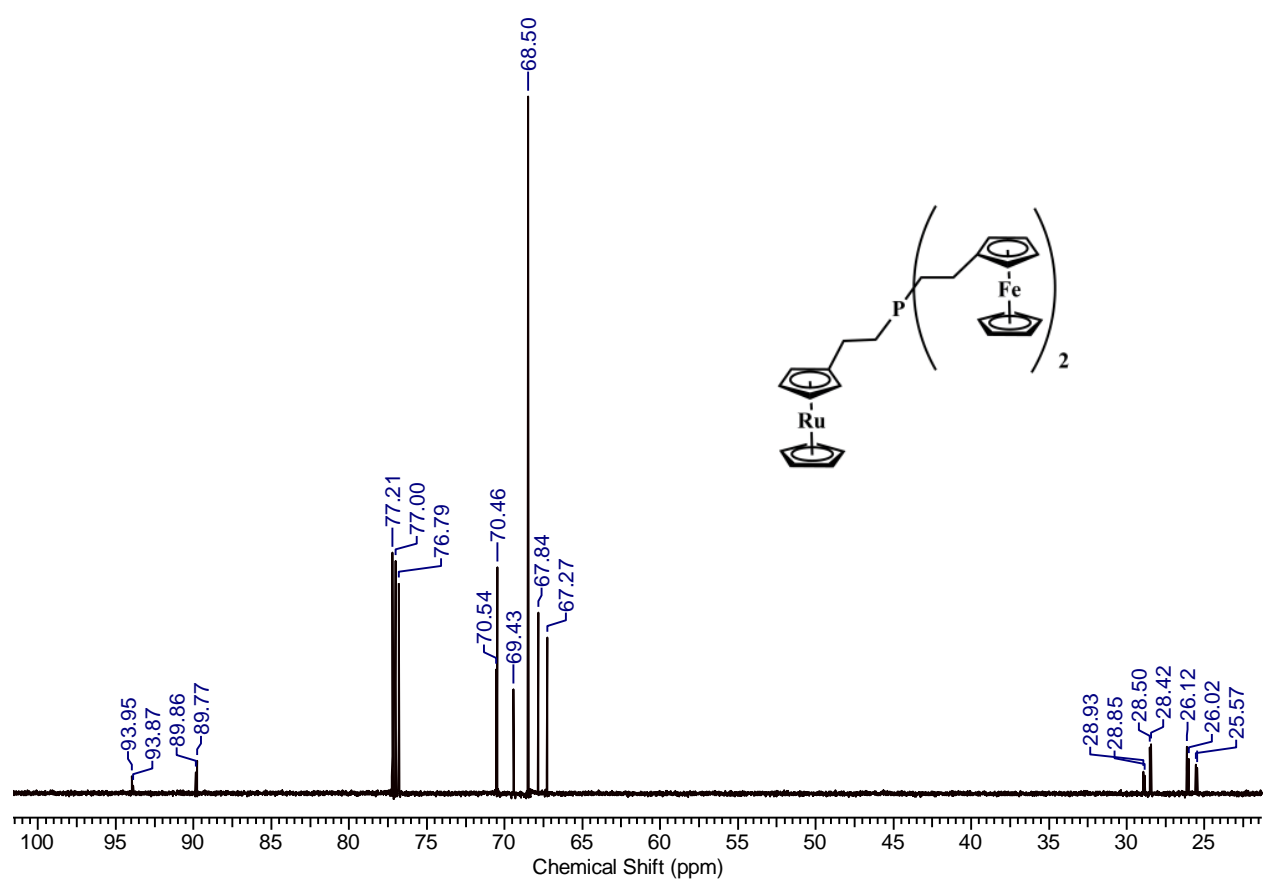

Figure S10. ${ }^{13} \mathrm{C}\left\{{ }^{1} \mathrm{H}\right\}$ NMR spectrum of tertiary phosphine 10 in $\mathrm{CDCl}_{3}$. 


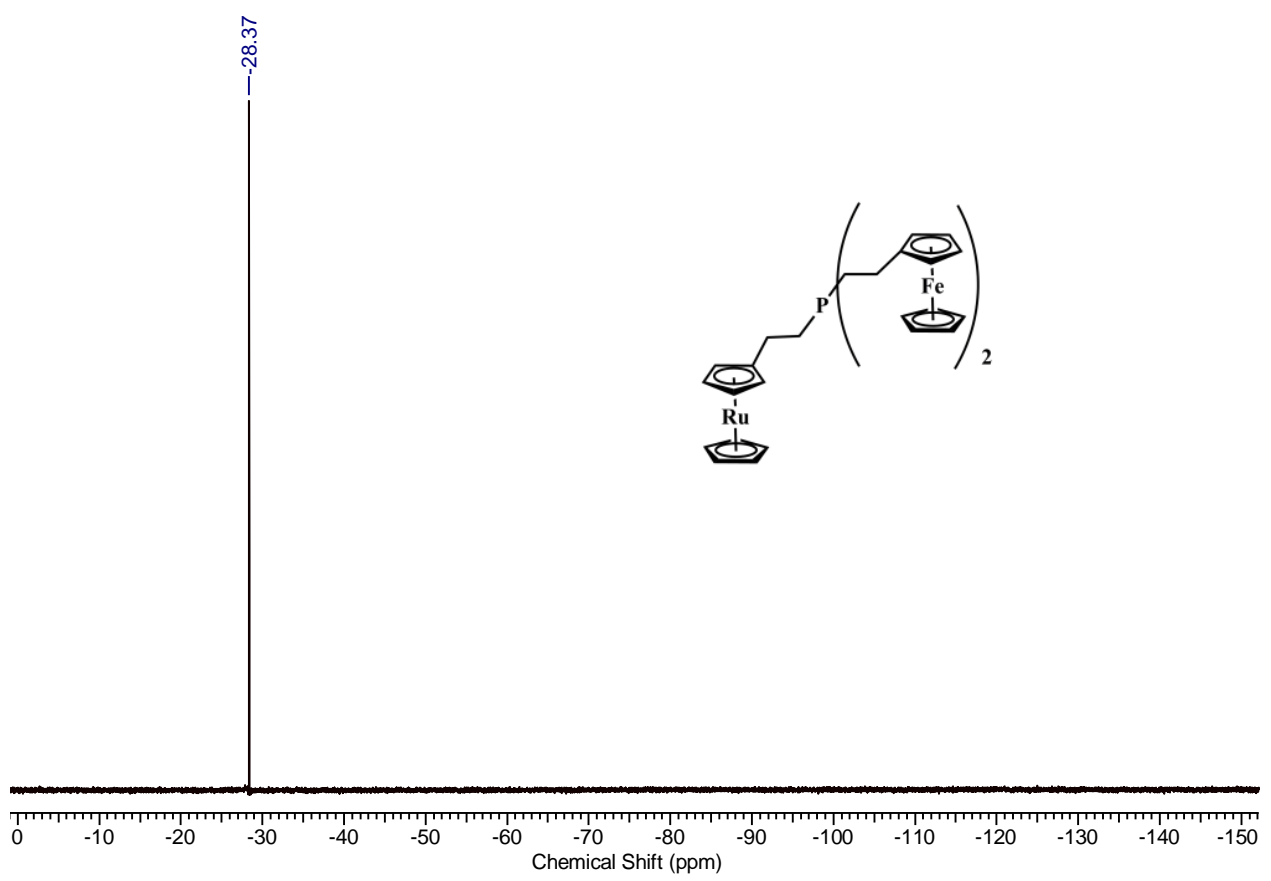

Figure S11. ${ }^{31} \mathrm{P}\left\{{ }^{1} \mathrm{H}\right\}$ NMR spectrum of tertiary phosphine 10 in $\mathrm{CDCl}_{3}$.

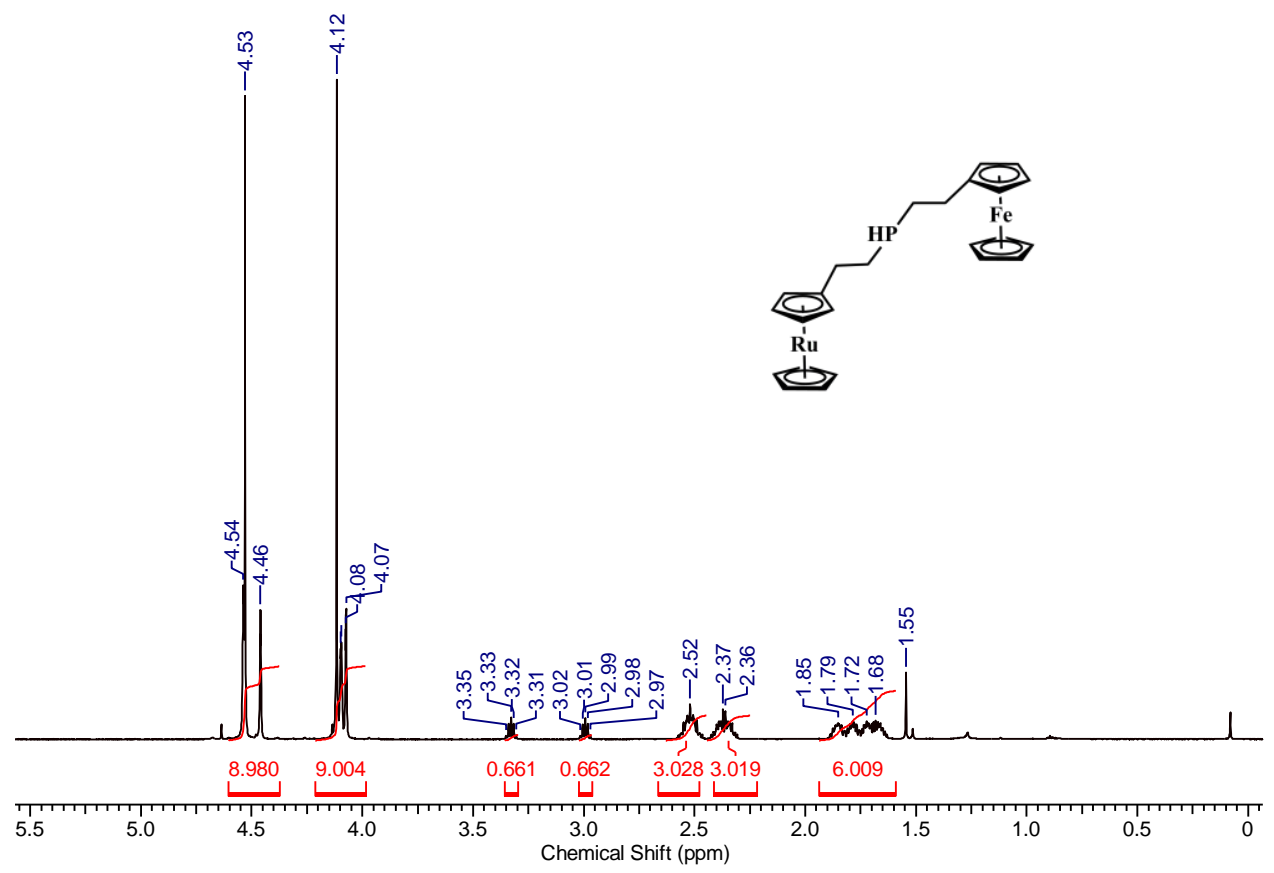

Figure S12. ${ }^{1} \mathrm{H}$ NMR spectrum of secondary phosphine 11 in $\mathrm{CDCl}_{3}$. 


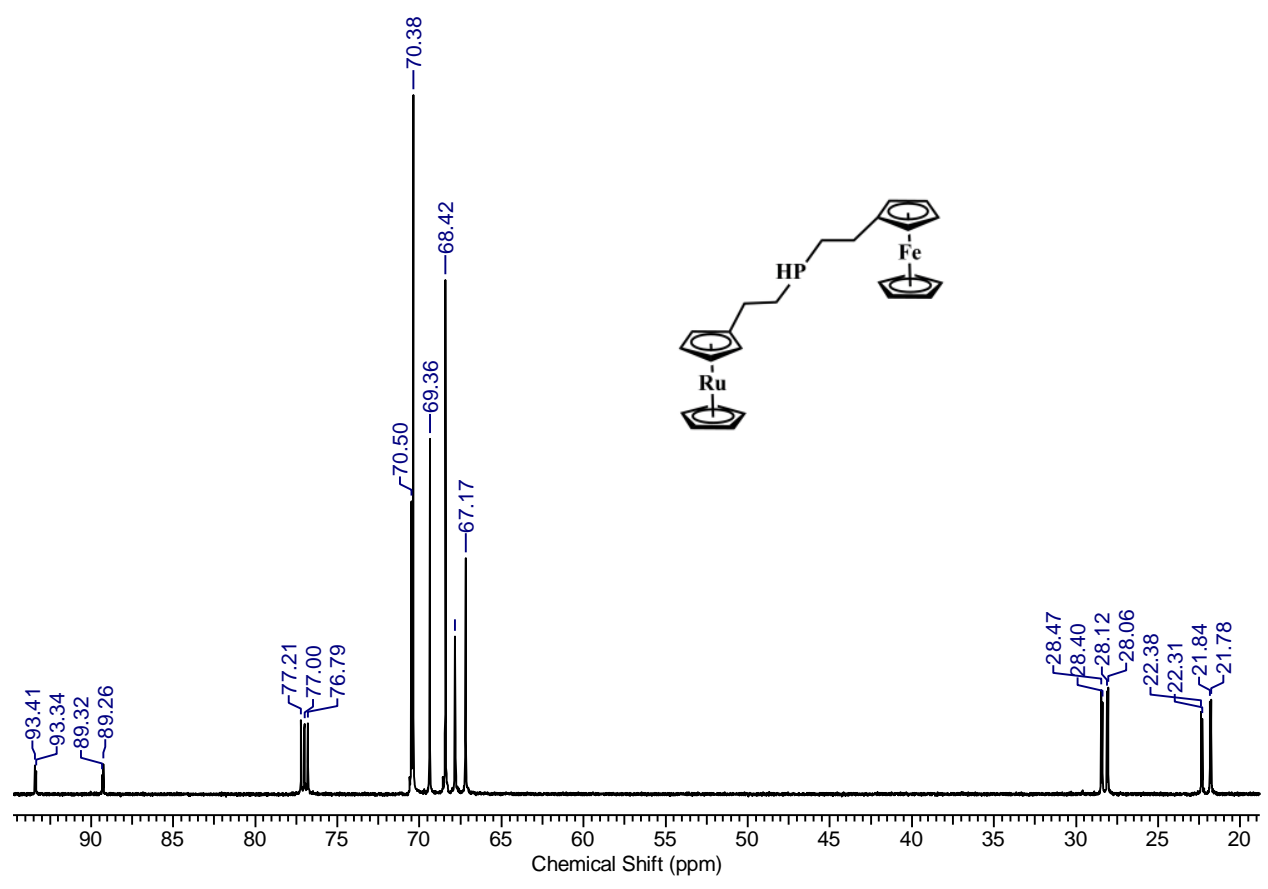

Figure S13. ${ }^{13} \mathrm{C}\left\{{ }^{1} \mathrm{H}\right\}$ NMR spectrum of secondary phosphine 11 in $\mathrm{CDCl}_{3}$.

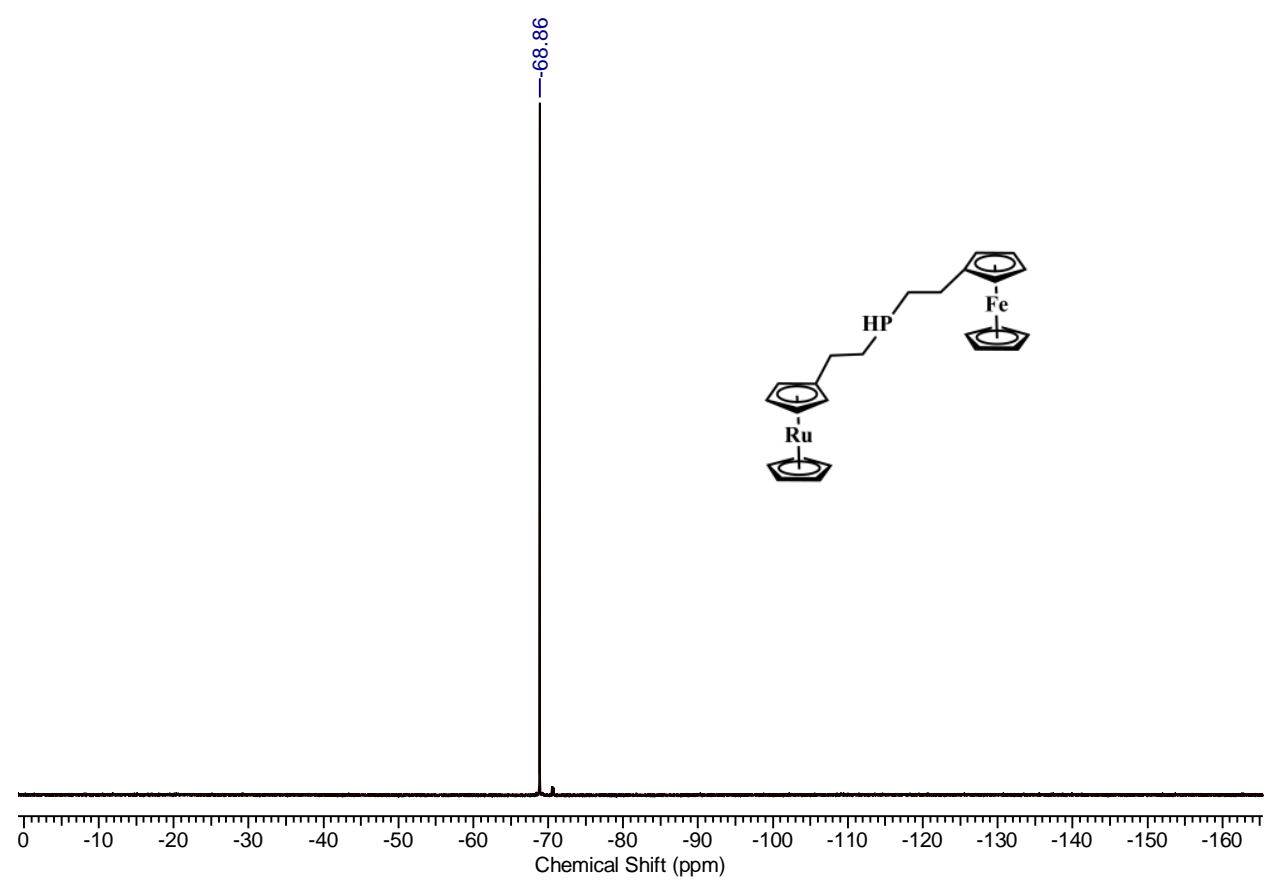

Figure S14. ${ }^{31} \mathrm{P}\left\{{ }^{1} \mathrm{H}\right\}$ NMR spectrum of secondary phosphine 11 in $\mathrm{CDCl}_{3}$. 


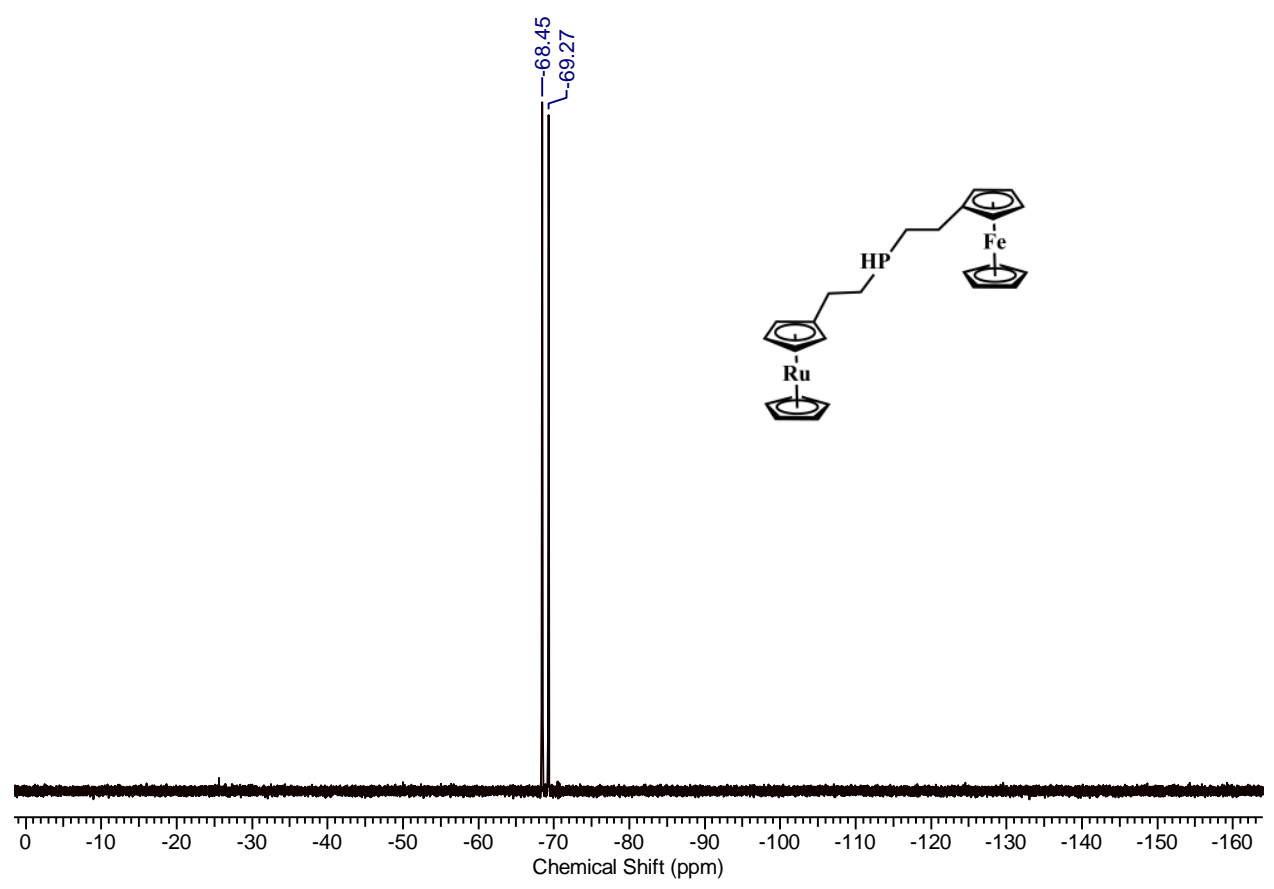

Figure S15. ${ }^{31} \mathrm{P}$ NMR spectrum of secondary phosphine 11 in $\mathrm{CDCl}_{3}$.

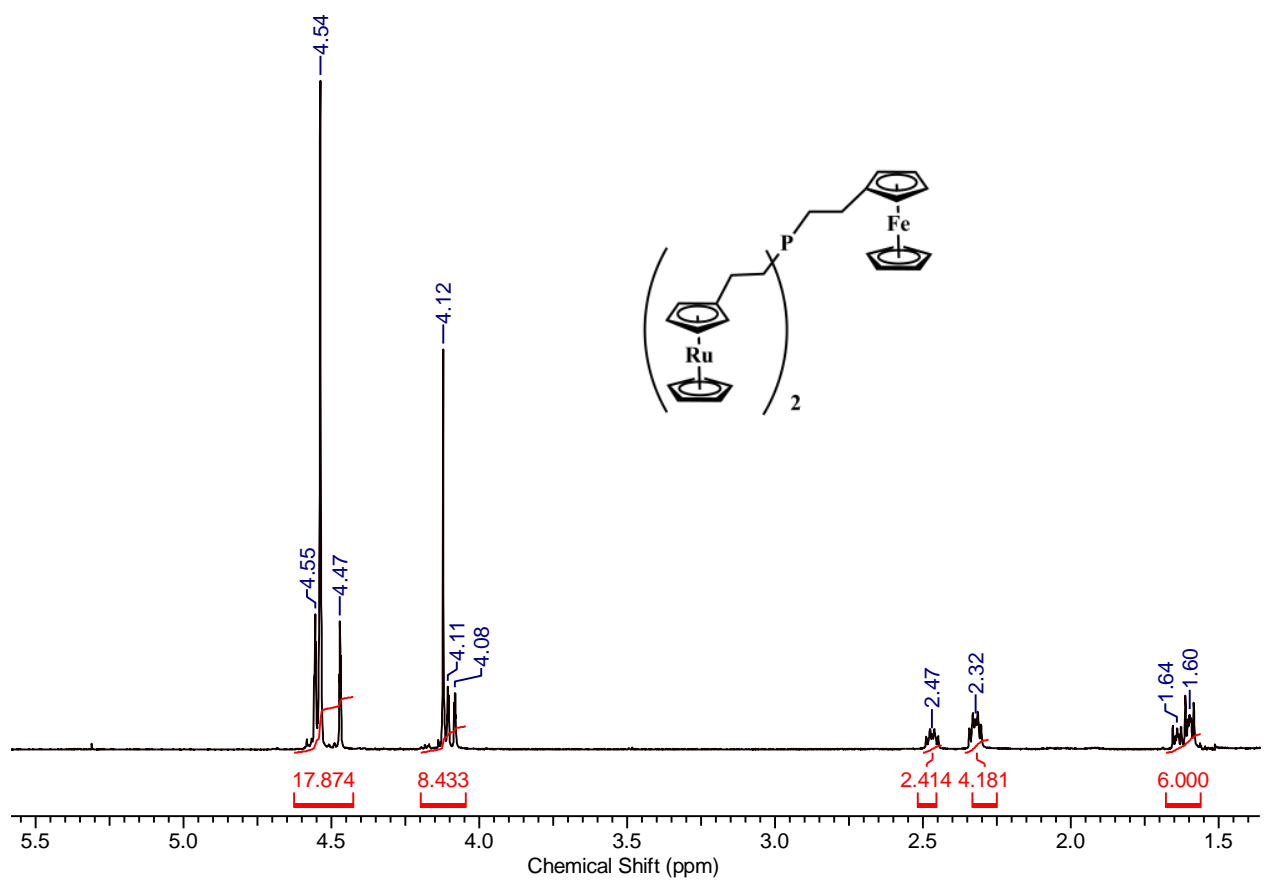

Figure S16. ${ }^{1} \mathrm{H}$ NMR spectrum of tertiary phosphine 12 in $\mathrm{CDCl}_{3}$. 


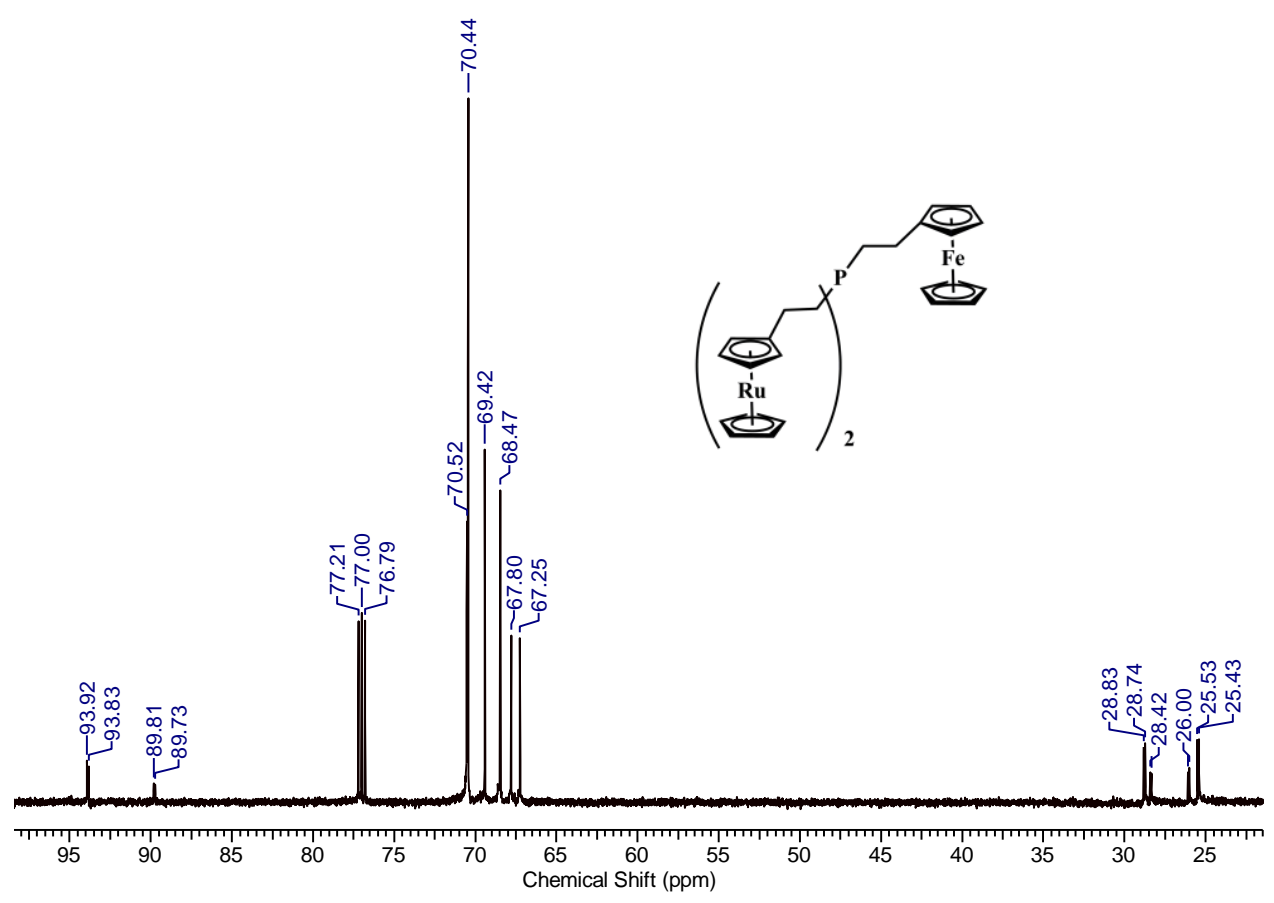

Figure S17. ${ }^{13} \mathrm{C}\left\{{ }^{1} \mathrm{H}\right\}$ NMR spectrum of tertiary phosphine 12 in $\mathrm{CDCl}_{3}$.

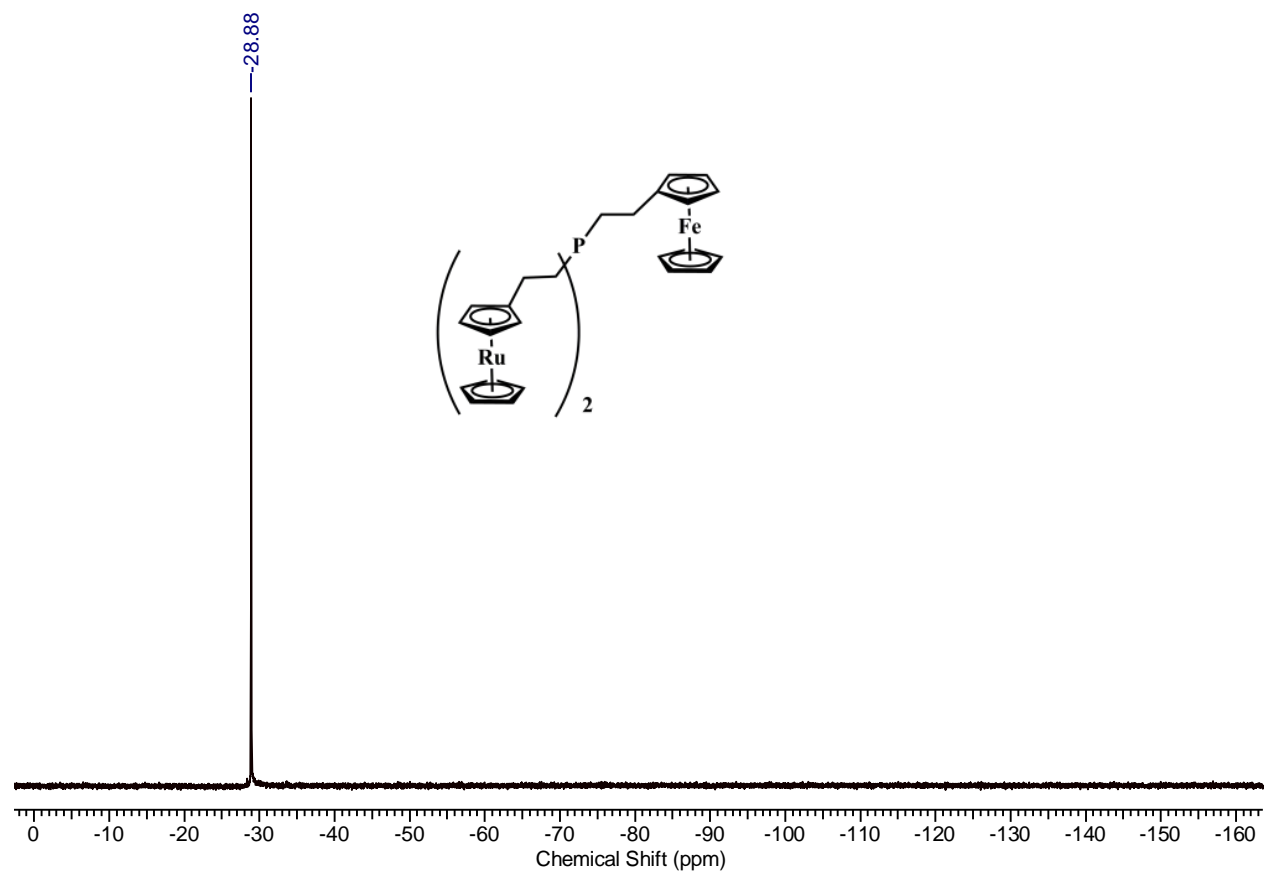

Figure S18. ${ }^{31} \mathrm{P}\left\{{ }^{1} \mathrm{H}\right\}$ NMR spectrum of tertiary phosphine 12 in $\mathrm{CDCl}_{3}$. 


\section{X-ray Diffraction Data Collection and Refinement Details}

Table S2. Selected X-ray diffraction data collection and refinement details for phosphines $\mathbf{8 b}$, $8 \mathrm{c}, \mathbf{1 0}, \mathbf{1 1}$, and 12 .

\begin{tabular}{|c|c|c|c|c|c|}
\hline & $\mathbf{8 b}$ & $8 c$ & 10 & 11 & 12 \\
\hline Chemical formula & $\mathrm{C}_{24} \mathrm{H}_{27} \mathrm{PRu}_{2}$ & $\mathrm{C}_{19} \mathrm{H}_{20.5} \mathrm{Cl}_{3} \mathrm{P}_{0.5} \mathrm{Ru}_{1.5}$ & $\mathrm{C}_{36} \mathrm{H}_{39} \mathrm{Fe}_{2} \mathrm{PRu}$ & $\mathrm{C}_{24} \mathrm{H}_{27} \mathrm{FePRu}$ & $\mathrm{C}_{36} \mathrm{H}_{39} \mathrm{FePRu}_{2}$ \\
\hline $\mathrm{FW}\left(\mathrm{g} \mathrm{mol}^{-1}\right)$ & 548.56 & 522.29 & 715.41 & 503.29 & 760.63 \\
\hline Temp (K) & 110 & 110 & 110 & 110 & 110 \\
\hline Crystal syst. & monoclinic & monoclinic & triclinic & monoclinic & triclinic \\
\hline Crystal habit & colorless plate & colorless plate & orange block & orange plate & yellow prism \\
\hline Space group & $\mathrm{C} 2 / \mathrm{c}$ & $\mathrm{P} 2_{1}$ & P-1 & $\mathrm{C} 2 / \mathrm{c}$ & P-1 \\
\hline$\lambda(\AA)$ & 0.71073 & 0.71073 & 0.71073 & 0.71073 & 0.71073 \\
\hline$a(\AA)$ & 29.614(4) & $5.778(3)$ & $11.190(2)$ & $32.299(10)$ & $11.188(2)$ \\
\hline $\mathrm{b}(\AA)$ & $5.7191(7)$ & 27.701(19) & $11.696(4)$ & $5.6826(12)$ & $11.744(4)$ \\
\hline c $(\AA)$ & $25.299(3)$ & 12.417(9) & $11.888(5)$ & $24.943(7)$ & $11.936(4)$ \\
\hline$\alpha(\operatorname{deg})$ & 90 & 90 & $84.94(2)$ & 90 & $84.99(2)$ \\
\hline$\beta(\operatorname{deg})$ & $108.331(6)$ & $100.311(17)$ & $83.442(18)$ & $116.23(2)$ & $84.428(15)$ \\
\hline$\gamma(\operatorname{deg})$ & 90 & 90 & $74.634(13)$ & 90 & $74.283(10)$ \\
\hline$V\left(\AA^{3}\right)$ & 4067.4(9) & 1955(2) & $1487.7(8)$ & $4107(2)$ & 1499.4(8) \\
\hline $\mathrm{Z}$ & 8 & 4 & 2 & 8 & 2 \\
\hline$\rho\left(\mathrm{g} \mathrm{cm}^{-3}\right)$ & 1.792 & 1.774 & 1.597 & 1.628 & 1.685 \\
\hline$\mu\left(\mathrm{cm}^{-1}\right)$ & 1.570 & 1.622 & 1.542 & 1.526 & 1.550 \\
\hline $\mathrm{R}_{1}[\mathrm{I}>2 \sigma(\mathrm{I})]$ & 0.0417 & 0.0453 & 0.0353 & 0.0433 & 0.0452 \\
\hline$w \mathrm{R}_{2}[\mathrm{I}>2 \sigma(\mathrm{I})]$ & 0.0993 & 0.0847 & 0.0755 & 0.0970 & 0.0806 \\
\hline $\mathrm{R}_{1}$ (all data) & 0.0469 & 0.0625 & 0.0496 & 0.0576 & 0.0789 \\
\hline$w \mathrm{R}_{2}$ (all data) & 0.1009 & 0.0909 & 0.0802 & 0.1035 & 0.0912 \\
\hline GOF & 1.140 & 1.060 & 1.044 & 1.071 & 0.990 \\
\hline
\end{tabular}

\section{Solid-State Structures}

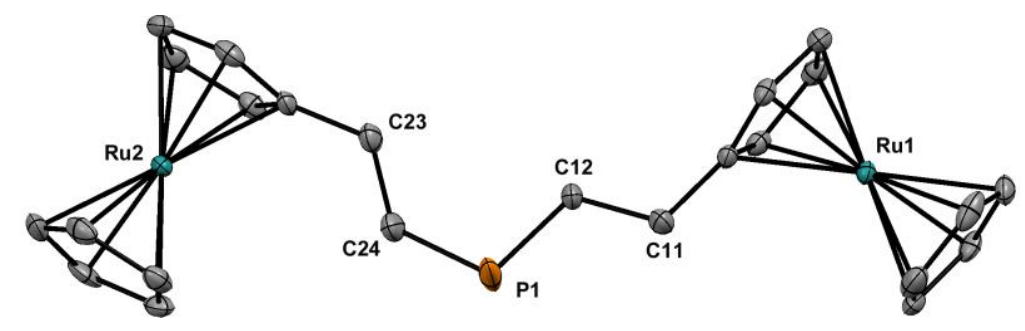

Figure S19. Solid-state structure of secondary phosphine $\mathbf{8 b}(2 \times \mathrm{Rc})$. Anisotropic displacement ellipsoids are shown at 50\% probability and hydrogen atoms have been omitted for clarity. 


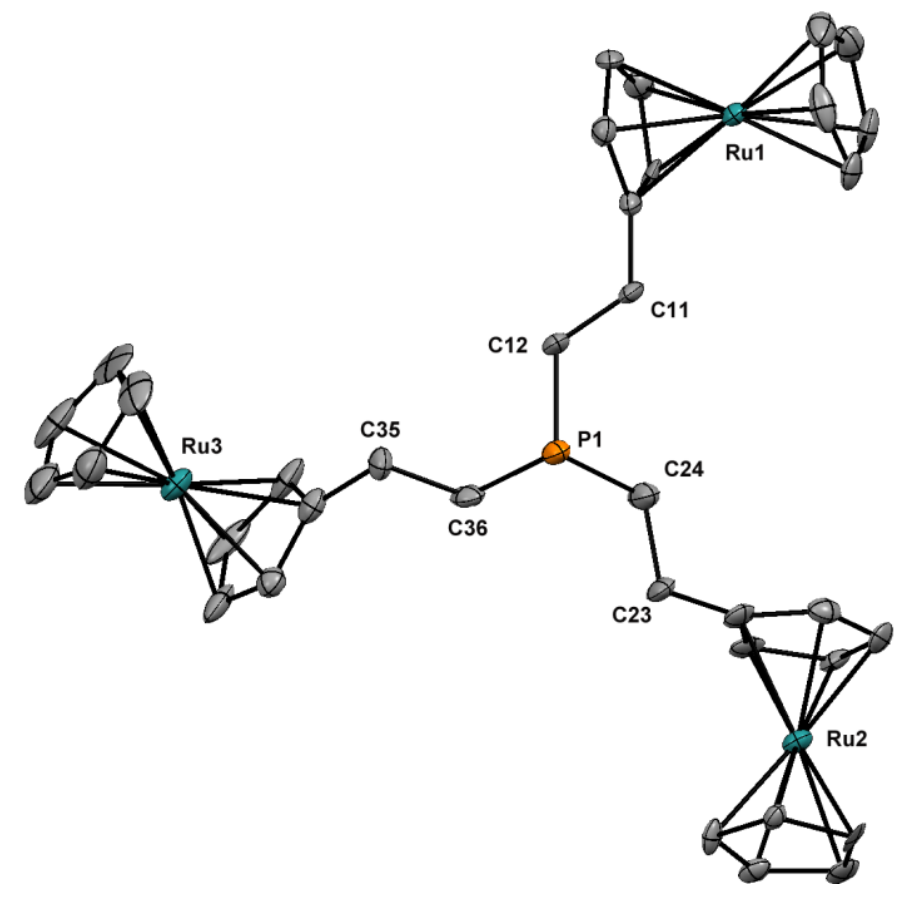

Figure S20. Solid-state structure of tertiary phosphine 8c $(3 \times \mathrm{Rc})$. Anisotropic displacement ellipsoids are shown at 50\% probability and hydrogen atoms have been omitted for clarity.

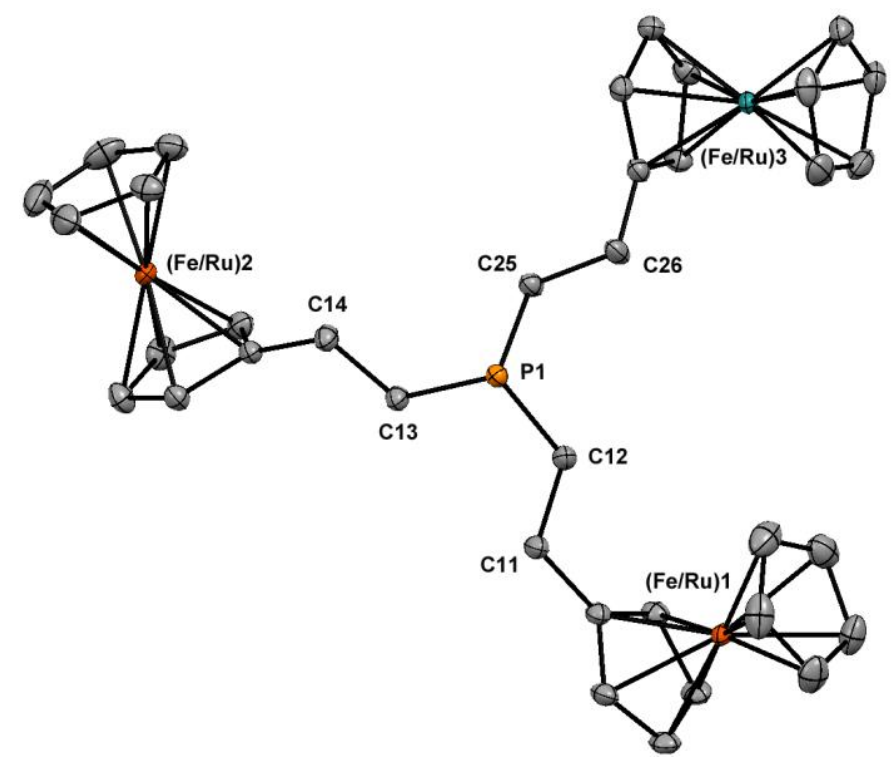

Figure S21. Solid-state structure of tertiary phosphine $\mathbf{1 0}(1 \times \mathrm{Rc}, 2 \times \mathrm{Fc})$. Anisotropic displacement ellipsoids are shown at 50\% probability and hydrogen atoms have been omitted for clarity. 


\section{Analysis of Twinning for $8 \mathrm{~b}$}

The diffraction pattern was successfully indexed as a non-merohedral twin wherein the domains were related by an approximate 180 degree rotation about [1-1-1]. The twin fraction for the minor domain refined to a value of $0.4120(7)$. The twin law is given below:

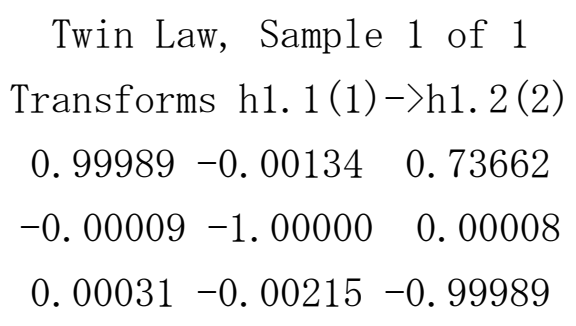

\section{UV-vis Absorption Spectra}

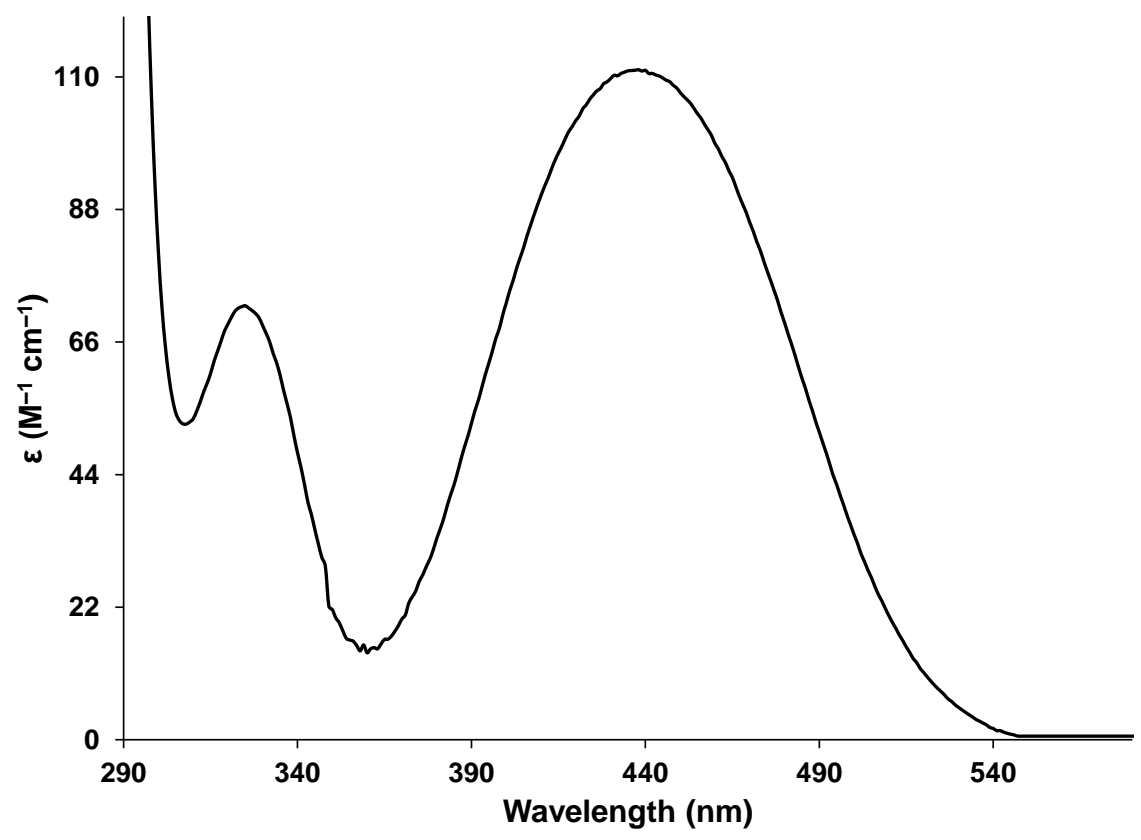

Figure S22. UV-vis absorption spectrum of primary phosphine $7 \mathbf{a}(1 \times \mathrm{Fc})$ in tetrahydrofuran. 


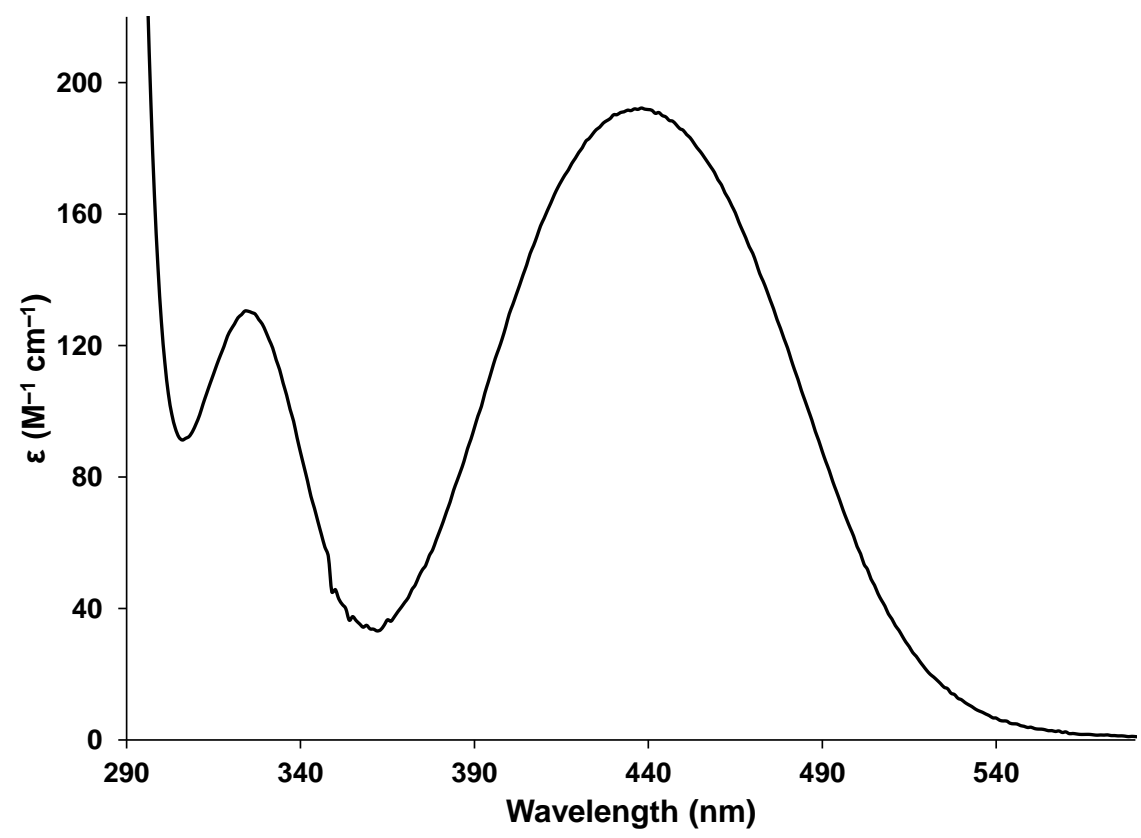

Figure S23. UV-vis absorption spectrum of secondary phosphine $7 \mathbf{b}(2 \times \mathrm{Fc})$ in tetrahydrofuran.

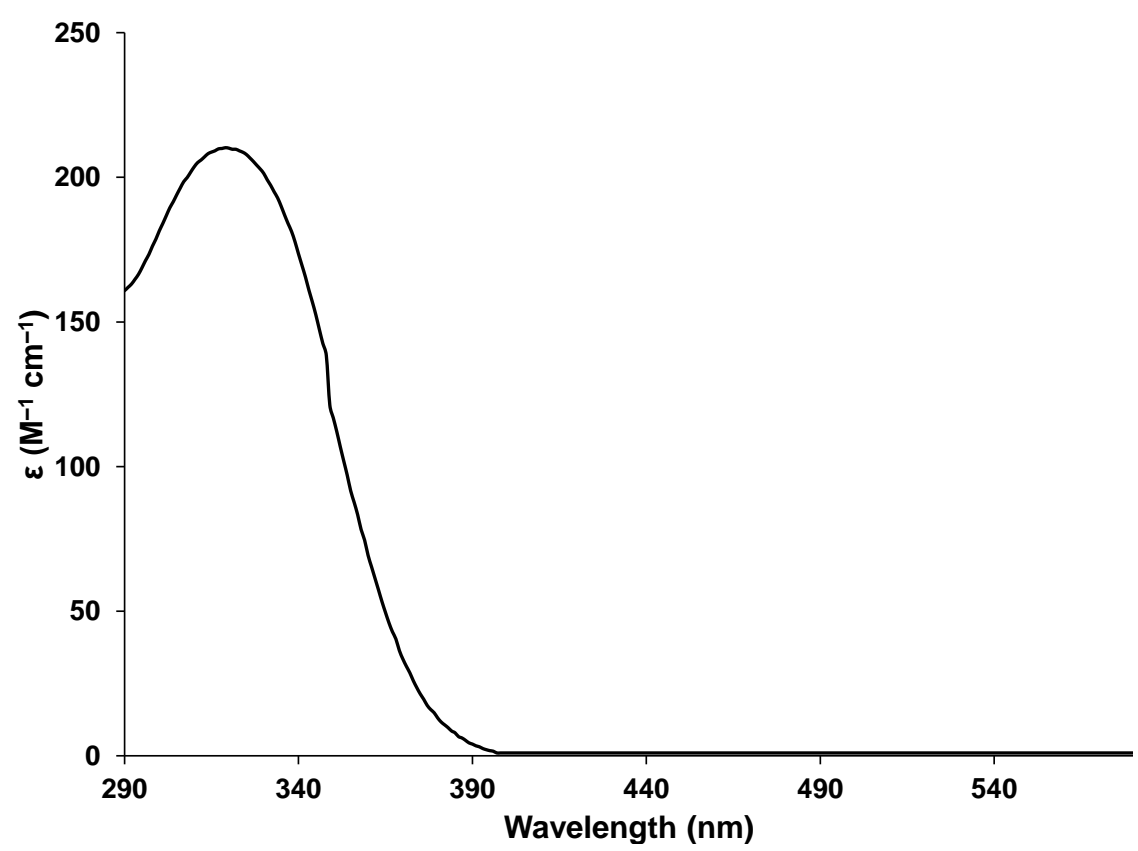

Figure S24. UV-vis absorption spectrum of primary phosphine $\mathbf{8 a}(1 \times \mathrm{Rc})$ in tetrahydrofuran. 


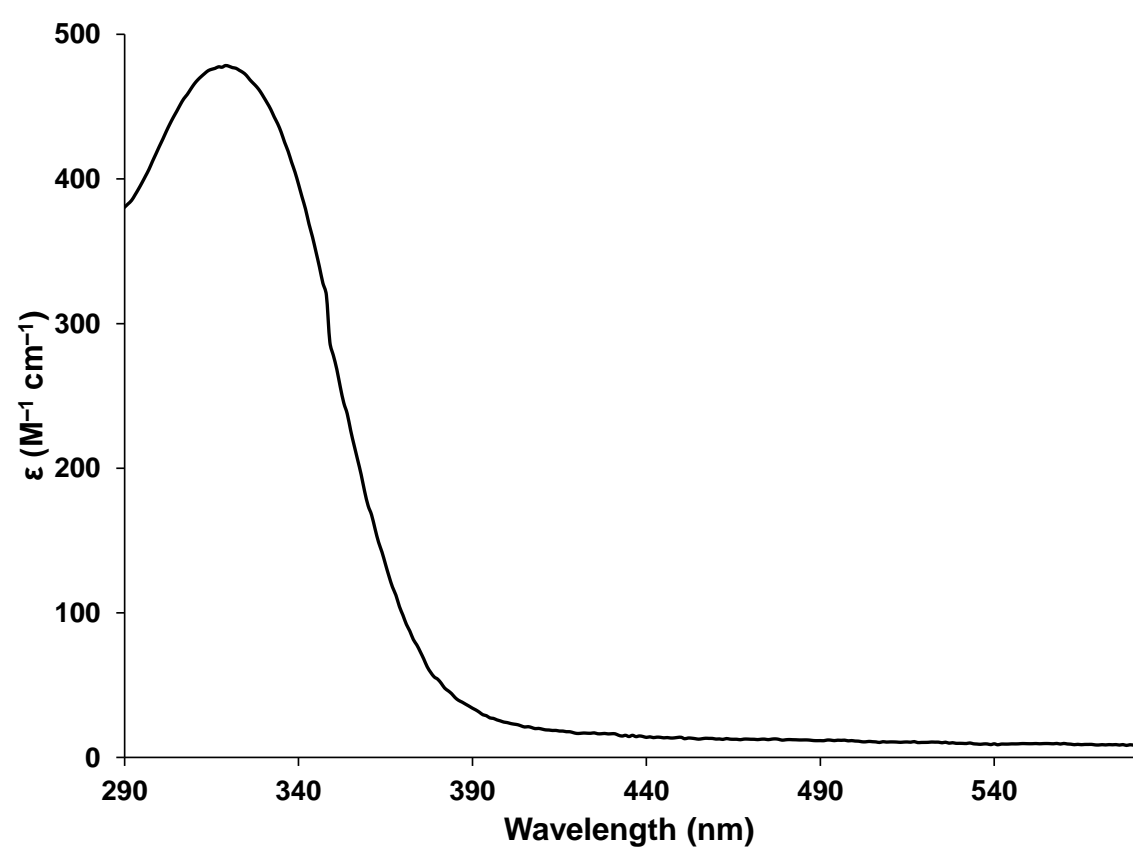

Figure S25. UV-vis absorption spectrum of secondary phosphine $\mathbf{8 b}(2 \times \mathrm{Rc})$ in tetrahydrofuran.

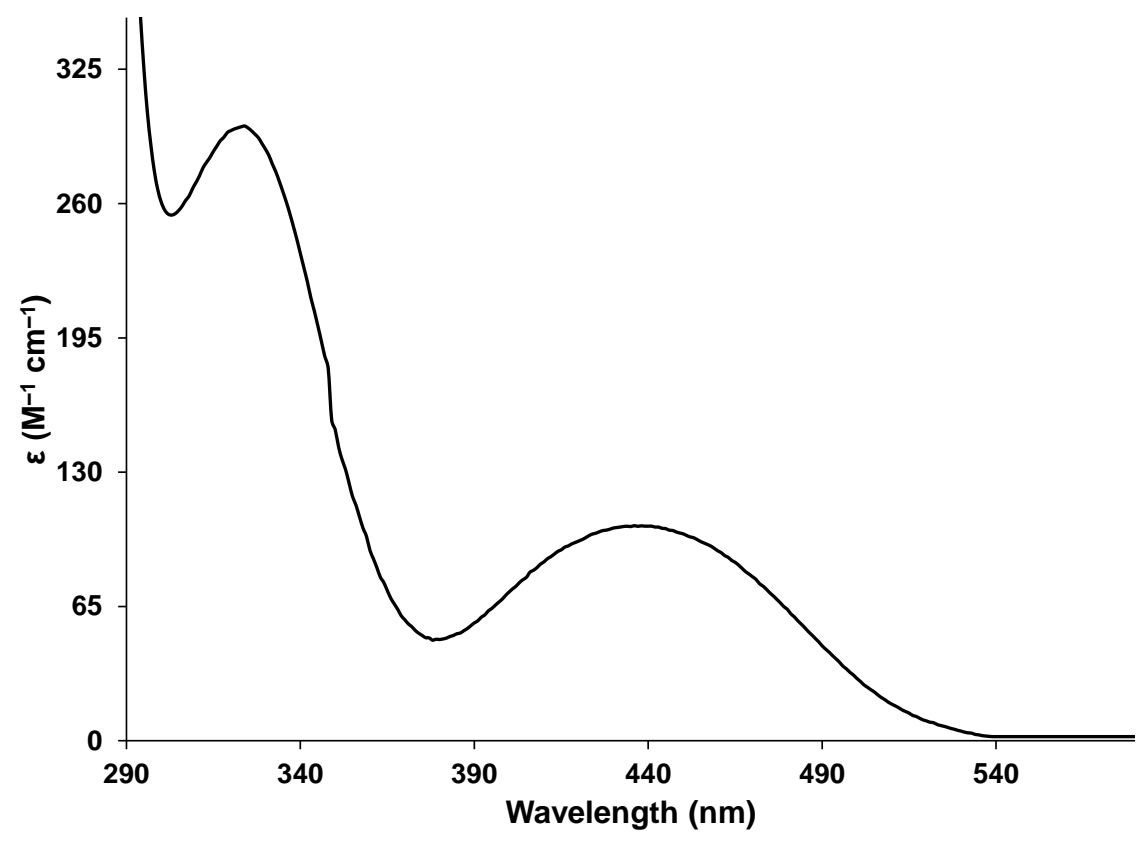

Figure S26. UV-vis absorption spectrum of secondary phosphine $11(1 \times \mathrm{Rc}, 1 \times \mathrm{Fc})$ in tetrahydrofuran. 


\section{Cyclic Voltammograms}
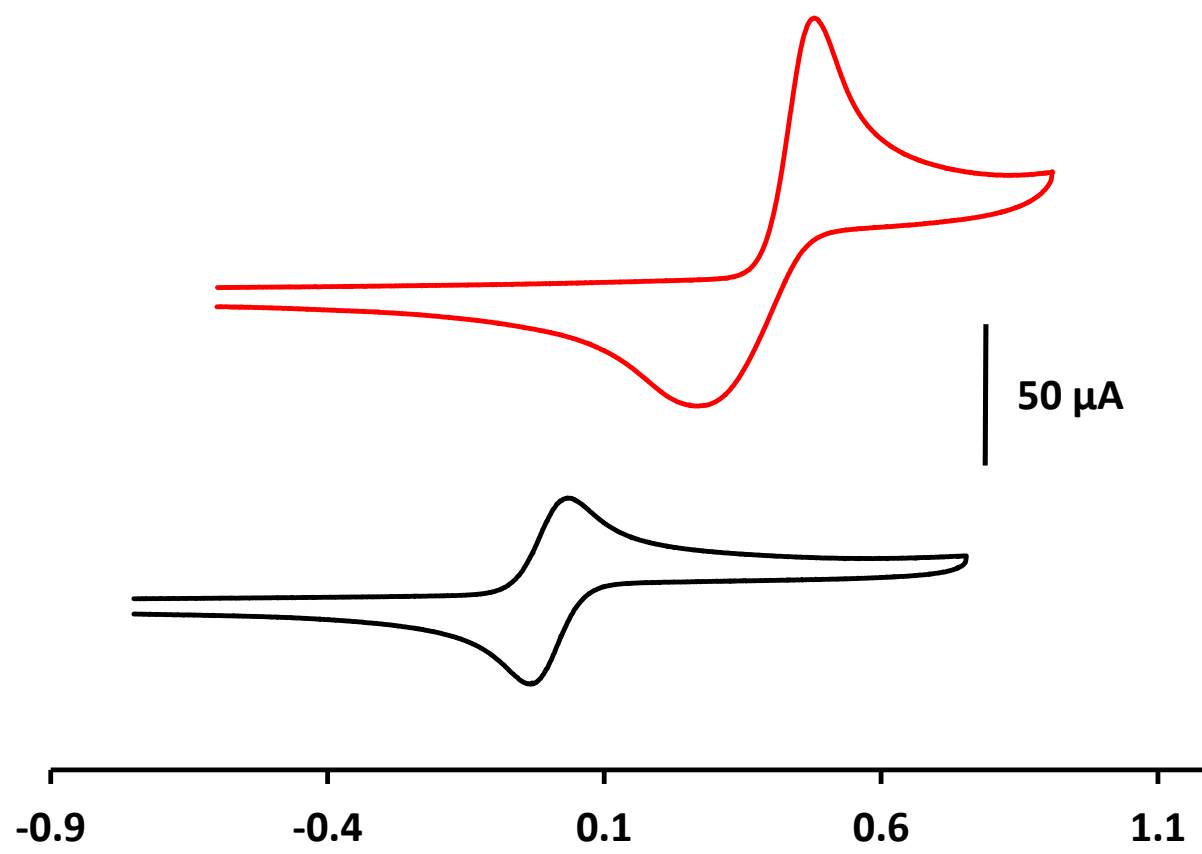

Potential (V vs. Ferrocene/Ferrocenium)

Figure S27. Cyclic voltammograms of ferrocene (black line) and ruthenocene (red line) recorded at $250 \mathrm{mV} \mathrm{s}^{-1}$ in $1 \mathrm{mM}$ solutions of dichloromethane containing $0.1 \mathrm{M}$ tetra- $n$-butylammonium triflate as supporting electrolyte.

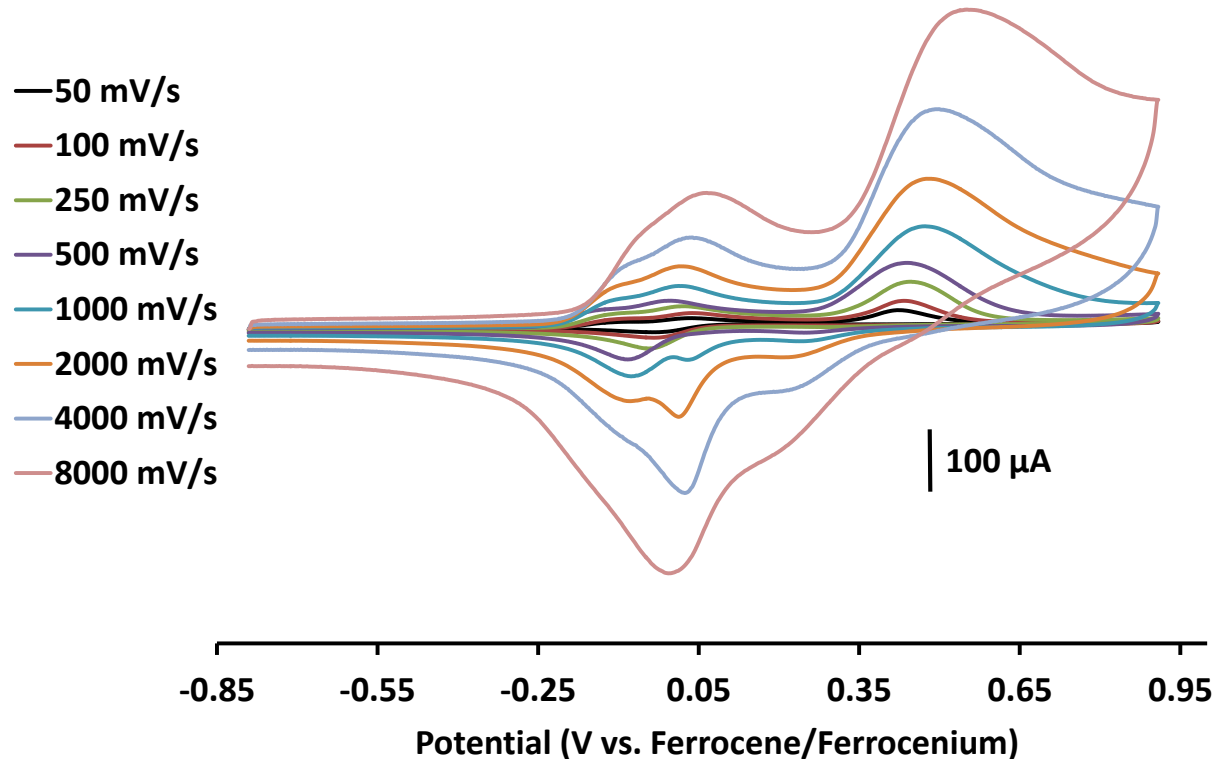

Figure S28. Cyclic voltammograms of tertiary phosphine $12(2 \times \mathrm{Rc}, 1 \times \mathrm{Fc})$ at different scan rates in $1 \mathrm{mM}$ solutions of dichloromethane containing $0.1 \mathrm{M}$ tetra- $n$-butylammonium triflate as supporting electrolyte. 


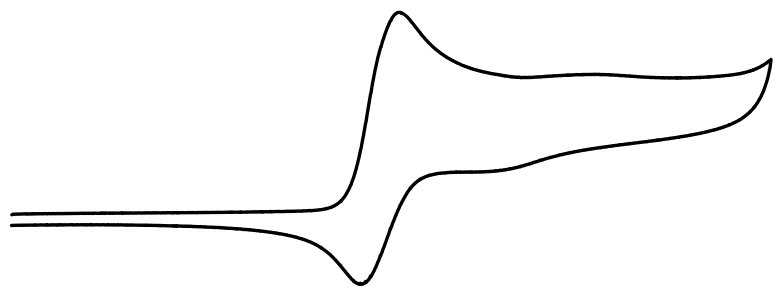

$50 \mu \mathrm{A}$
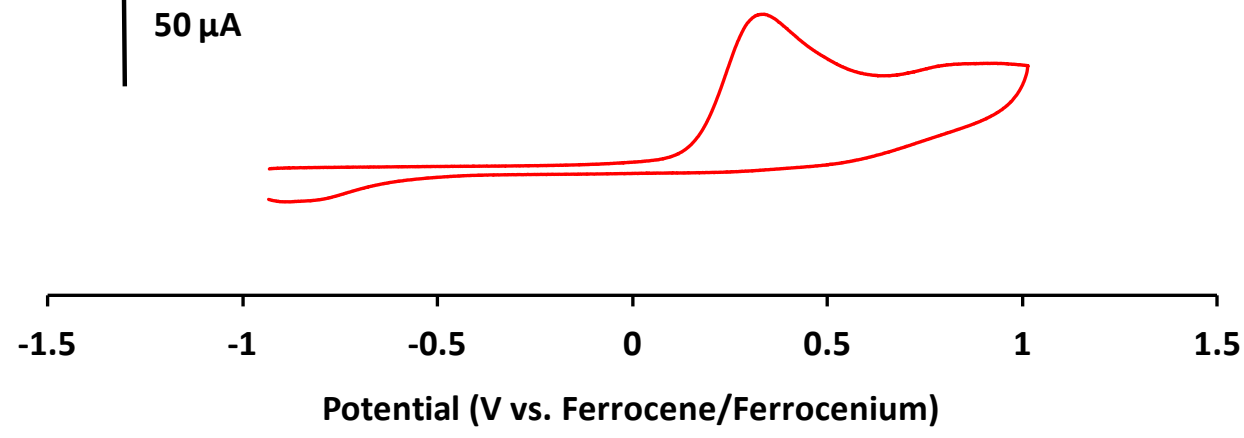

Figure S29. Cyclic voltammograms of 7a $(1 \times \mathrm{Fc}$, black line $)$ and $\mathbf{8 a}(1 \times \mathrm{Rc}$, red line $)$ recorded at $250 \mathrm{mV} \mathrm{s}^{-1}$ in $1 \mathrm{mM}$ solutions of dichloromethane containing $0.1 \mathrm{M}$ tetra- $n$-butylammonium triflate as supporting electrolyte.

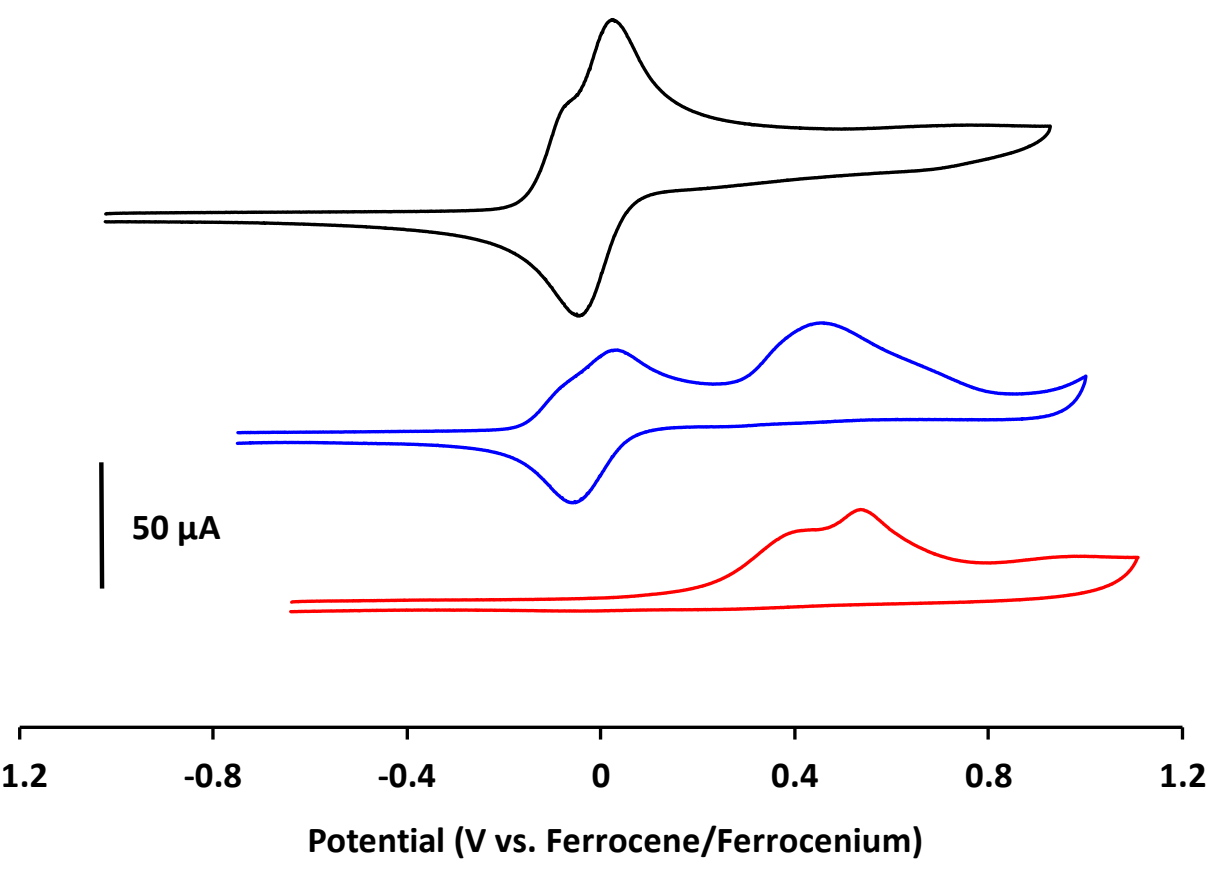

Figure S30. Cyclic voltammograms of secondary phosphines $7 \mathbf{b}(2 \times \mathrm{Fc}$, black line $), \mathbf{8 b}(2 \times \mathrm{Rc}$, red line), and $11\left(1 \times \mathrm{Rc}, 1 \times \mathrm{Fc}\right.$, blue line) recorded at $250 \mathrm{mV} \mathrm{s}^{-1}$ in $1 \mathrm{mM}$ solutions of dichloromethane containing $0.1 \mathrm{M}$ tetra- $n$-butylammonium triflate as supporting electrolyte. 

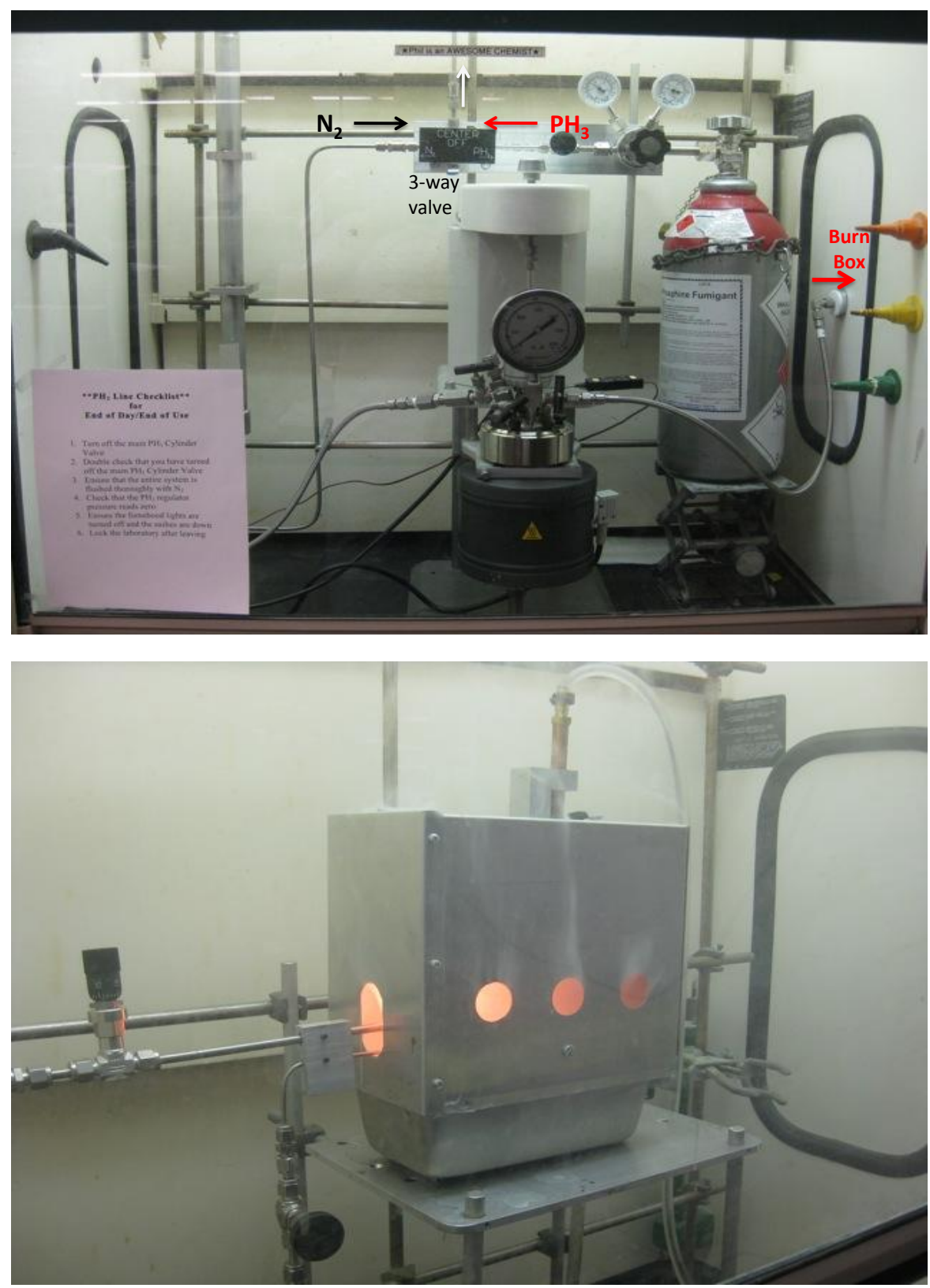

Figure S31. Photographs of the reaction setup (top) and burn box (bottom) used for the safe handling and disposal of $\mathrm{PH}_{3}$ gas during this study. 